\title{
FY-87 Packing Fabrication Techniques (Commercial Waste Form) Results
}
E. V. Werry
T. E. Gates
K. S. Cabbage
J. D. Eklund

\section{April 1988}

Prepared for the U.S. Department of Energy under Contract DE-AC06-76RLO 1830

Pacific Northwest Laboratory Operated for the U.S. Department of Energy by Battelle Memorial Institute 


\title{
DISCLAIMER
}

This report was prepared as an account of work sponsored by an agency of the United States Government. Neither the United States Government nor any agency thereof, nor Battelle Memorial Institute, nor any or their employees, makes any warranty, expressed or implied, or assumes any legal liability or responsibility for the accuracy, completeness, or usefulness of any information, apparatus, product, or process disclosed, or represents that its use would not infringe privately owned rights. Reference herein to any specific commercial product, process, or service by trade name, trademark, manufacturer, or otherwise does not necessarily constitute or imply its endorsement, recommendation, or favoring by the United States Government or any agency thereof, or Battelle Memorial Institute. The views and opinions of authors expressed herein do not necessarily state or reflect those of the United States Government or any agency thereof, or Battelle Memorial Institute.

\author{
PACIFIC NORTHWEST LABORATORY \\ operated by \\ BATTELLE MEMORIAL INSTITUTE \\ for the \\ UNITED STATES DEPARTMENT OF ENERGY \\ under Contract DE-AC06-76RLO 1830
}

\author{
Printed in the United States of America \\ Available from \\ National Technical Information Service \\ United States Department of Commerce \\ 5285 Port Royal Road \\ Springfield, Virginia 22161 \\ NTIS Price Codes \\ Microfiche A01
}

Printed Copy

$\begin{array}{lr}\text { Pages } & \begin{array}{c}\text { Price } \\ \text { Codes }\end{array} \\ 001-025 & \text { A02 } \\ 026-050 & \text { A03 } \\ 051-075 & \text { A04 } \\ 076-100 & \text { A05 } \\ 101-125 & \text { A06 } \\ 126-150 & \text { A07 } \\ 151-175 & \text { A08 } \\ 176-200 & \text { A09 } \\ 201-225 & \text { A010 } \\ 226-250 & \text { A011 } \\ 251-275 & \text { A012 } \\ 276-300 & \text { A013 }\end{array}$


PNL -6532

UC-70

FY-87 PACKING FABRICATION TECHNIQUES

(COMMERCIAL WASTE FORM) RESULTS
E. V. Werry
T. E. Gates
K. S. Cabbage
J. D. Eklund

Apri] 1988

Prepared for

the U.S. Department of Energy

under Contract DE-ACD6-76RLO 1830

Pacific Northwest Laboratory

Richland, Washington 99352 



\section{SUMMARY}

This report covers the investigation of fabrication techniques associated with the development of suitable materials and methods to provide a prefabricated packing for waste packages for the Basalt Waste Isolation Project (BWIP). The principal functions of the packing are to minimize container corrosion during the 300 to 1000 years following repository closure and provide long-term control of the release of radionuclides from the waste package. The investigative work, discussed in this report, was specifically conceived to develop the design criteria for production of full-scale prototypical packing rings.

The investigative work included the preparation of procedures, the preparation of fabrication materials, physical properties, and the determination of the engineering properties. The principal activities were the preparation of the materials and the determination of the physical properties.

Central to all of the investigative work was the development of basalt/ bentonite mixtures with relation to various compaction techniques that would provide a minimum dry density of $2.0 \mathrm{~g} / \mathrm{cm}^{3}\left(125 \mathrm{lb} / \mathrm{ft}^{3}\right)$. Other work was the investigation of the associated unconfined compressive and splitting tensile strengths of the packing mixtures under various states of controlled drying.

The Talbot (PNL 1986), basalt only, gradation was chosen as the primary mix design; this gradation was experimentally adjusted to obtain effective mixtures of $85 \%$ basalt/ $15 \%$ bentonite, $75 \%$ basalt $/ 25 \%$ bentonite and $65 \%$ basalt/35\% bentonite. The adjustments to the basalt Talbot gradation were made by scalping the basalt fines and replacing it with an equal percentage of bentonite. Water contents of $9 \%$ to $13 \%$ were added to the mixture to determine the optimum moisture content and the maximum dry density. These mixtures were compacted by the Proctor or the hydraulic static compaction method. The hydraulic static compaction loads ranged from $11,530 \mathrm{kPa}$ (1672 psi) to $15,920 \mathrm{kPa}(2309 \mathrm{psi})$. The Proctor tests were carried out using ASTM 
Standards (ASTM 1986b). Compaction by vibration plus static load was also investigated; however, these tests proved to be unsuccessful and were abandoned as a viable method to achieve the $2.0 \mathrm{~g} / \mathrm{cm}^{3}\left(125 \mathrm{lbs} / \mathrm{ft}^{3}\right)$ minimum density.

A series of tests was conducted to determine "comparative" unconfined compressive strength for the $85 \%$ basalt/15\% bentonite and the $75 \%$ basalt/25\% bentonite mixtures. By definition "comparative" is the comparison of strength properties between the compaction methods, i.e., the standard Proctor test and the alternate hydraulic static compaction. The unconfined compressive strength tests were conducted on both oven dried and atmospheric dried samples (inside the $l a b$ and outside the lab). Stress/strain curves were developed for each mixture and compaction method. Strength comparisons were made between the two (Proctor vs hydraulic static) compaction methods.

Tensile strength tests were also conducted. Two testing methods, direct and indirect, were investigated for conducting tensile strength testing. A series of splitting tensile strength tests was conducted on the $85 \%$ basalt/ $15 \%$ bentonite Talbot mixture using the splitting tensile indirect method. Twe Tve test specimens, $101.6 \mathrm{~mm}$ ( 4 in.) diameter, were fabricated using the hydraulic static compaction method. Six specimens were compacted at 11,530 $\mathrm{kPa}(1672 \mathrm{psi})$ and the other six at $15,920 \mathrm{kPa}(2309 \mathrm{psi})$. Half of each group of specimens was dried and tested and the remaining half was tested moist.

The principal findings of the packing-fabrication investigations during FY 87 were:

- The Talbot gradation has proven to be a reliable mix design to develop packing mixtures. The testing has shown good correlation to the ralbot gradation.

- Both the Proctor (tamping) compaction and hydraulic compaction methods meet the minimum dry densities, $2.0 \mathrm{~g} / \mathrm{cm}^{3}\left(125 \mathrm{lb} / \mathrm{ft}^{3}\right)$.

- Laboratory scale compaction density results have shown good repeatability. 
- Comparisons of compaction methods indicate that the hydrautic static compaction provides the highest results.

- Compaction by Proctor or hydraulic static compaction indicates that the $85 \%$ basalt $/ 15 \%$ bentonite mixture provides higher unconfined compressive strength and tensile strength values. This mix also has less dependency upon water content.

- Drying of the specimens has produced a favorable change in the unconfined compressive strength. The drier the sample the higher the intermediate and ultimate strengths.

- Unconfined compressive strength values from $2480 \mathrm{kPa}$ (360 psi) to 4217 $\mathrm{kPa}(612 \mathrm{psi})$ were observed in the tested specimens. The hydraulic static compaction method resulted in the larger values, i.e., about 1.6 times larger than the Proctor compacted specimens.

- The specimens compacted at the higher pressure (loads) yielded average splitting tensile strengths higher than those compacted at the lower pressures, i.e., $187 \mathrm{kPa}(27 \mathrm{psi})$ dried and $136 \mathrm{kPa}(20 \mathrm{psi})$ moist vs $148 \mathrm{kPa}(21 \mathrm{psi}) \mathrm{dried}$ and $101 \mathrm{kPa}$ (15 psi) moist.

- The compacted densities of both groups were within 3\% of each other, yet the specimens compacted at the higher pressure yielded unproportionately higher strength indicating that achieved density may not be a good indicator of expected tensile strength. 


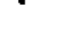




\section{ACKNOWLEDGMENTS}

The authors wish to acknowledge contributions to this study by the following staff: from the Westinghouse Hanford Company our thanks for their continued support throughout the course of these studies, J. C. Krogness, Activity Manager, Waste Package Program, R. V. Vaddey, Technical Contact for Packing Development and C. A. Givens, Cognizant Engineer, Packing Development; from the Pacific Northwest Laboratory, V. C. Lauhala, QAE, for his assistance and review of the report, Dr. G. W. Gee, a special thanks for his timely technical review of the report, T. S. Ceckiewicz for his contribution of technical editing and to C. H. Connally, a special thanks for her many, long and late hours of word processing assistance. 



\section{$\underline{\text { CONTENTS }}$}

SUMMARY

i i i

ACKNOWLEDGMENTS

vii

INTRODUCTION $\quad \ldots \ldots \ldots \ldots \ldots \ldots \ldots \ldots \ldots \ldots \ldots \ldots \ldots \ldots \ldots \ldots \ldots \ldots \ldots$

MECHANICAL DEVELOPMENT LABORATORY $\ldots \ldots \ldots \ldots \ldots \ldots \ldots \ldots \ldots \ldots \ldots \ldots$

MATERIALS USED FOR TESTING $\ldots \ldots \ldots \ldots \ldots \ldots \ldots \ldots \ldots \ldots \ldots \ldots \ldots \ldots \ldots$

WHC BASALT/BENTONITE $\quad \ldots \ldots \ldots \ldots \ldots \ldots \ldots \ldots \ldots \ldots \ldots \ldots \ldots$

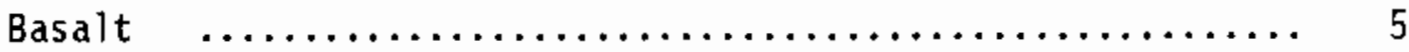

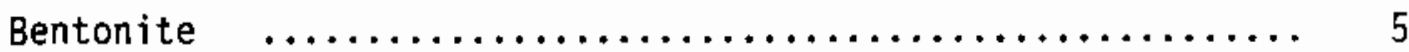

PHYSICAL PROPERTIES $\quad \ldots \ldots \ldots \ldots \ldots \ldots \ldots \ldots \ldots \ldots \ldots \ldots \ldots \ldots \ldots \ldots$

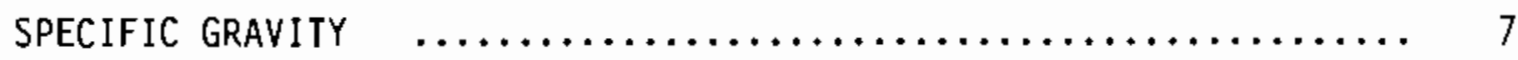

AGGREGATE GRADATION $\quad \ldots \ldots \ldots \ldots \ldots \ldots \ldots \ldots \ldots \ldots \ldots \ldots \ldots \ldots$

The Talbot Mix Design $\quad \ldots \ldots \ldots \ldots \ldots \ldots \ldots \ldots \ldots \ldots \ldots$

PACKING MIXTURES $\quad \ldots \ldots \ldots \ldots \ldots \ldots \ldots \ldots \ldots \ldots \ldots \ldots \ldots \ldots$

Raw Materials Basalt and Bentonite $\ldots \ldots \ldots \ldots \ldots \ldots \ldots$. 8

Water Content $\quad \ldots \ldots \ldots \ldots \ldots \ldots \ldots \ldots \ldots \ldots \ldots \ldots \ldots \ldots \ldots \ldots$

Mellowing of Mixtures $\quad \ldots \ldots \ldots \ldots \ldots \ldots \ldots \ldots \ldots \ldots \ldots \ldots$

ENGINEERING PROPERTIES $\quad \ldots \ldots \ldots \ldots \ldots \ldots \ldots \ldots \ldots \ldots \ldots \ldots \ldots \ldots \ldots \ldots \ldots \ldots 11$

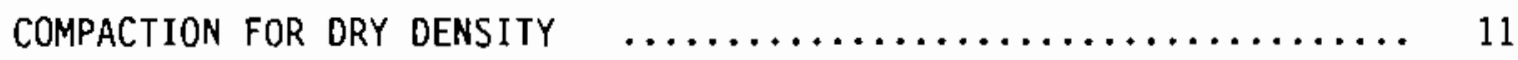

Proctor Compaction (Tamping) $\ldots \ldots \ldots \ldots \ldots \ldots \ldots \ldots \ldots \ldots \ldots$

Vibration Plus Static Load Compaction $\ldots \ldots \ldots \ldots \ldots \ldots \ldots$

Static Compaction by Hydraulic Ram $\ldots \ldots \ldots \ldots \ldots \ldots \ldots \ldots$

STRENGTH OF COMPACTED PACKING MATERIALS MIXTURES $\ldots \ldots \ldots \ldots \ldots \ldots .31$

Sample Drying Techniques $\quad \ldots \ldots \ldots \ldots \ldots \ldots \ldots \ldots \ldots \ldots \ldots \ldots \ldots$

Unconfined Compressive Strength $\quad \ldots \ldots \ldots \ldots \ldots \ldots \ldots \ldots \ldots$

Tensile Strength $\quad \ldots \ldots \ldots \ldots \ldots \ldots \ldots \ldots \ldots \ldots \ldots \ldots \ldots \ldots \ldots$ 


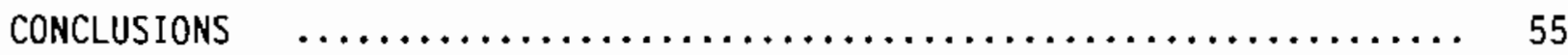

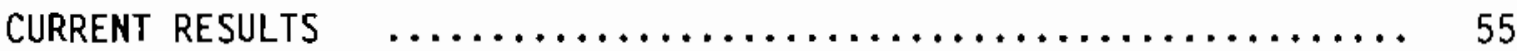

Gradations/Packing Mixtures $\quad \ldots \ldots \ldots \ldots \ldots \ldots \ldots \ldots \ldots \ldots \ldots$

Packing Dry Densities $\quad \ldots \ldots \ldots \ldots \ldots \ldots \ldots \ldots \ldots \ldots \ldots \ldots \ldots \ldots$

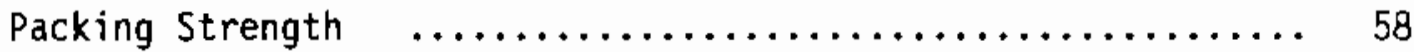

ADDITIONAL LABORATORY SCALE WORK $\ldots \ldots \ldots \ldots \ldots \ldots \ldots \ldots \ldots \ldots \ldots \ldots \ldots \ldots \ldots \ldots \ldots$

Compaction of Mixtures $\quad \ldots \ldots \ldots \ldots \ldots \ldots \ldots \ldots \ldots \ldots \ldots \ldots$

Drying Methods $\quad \ldots \ldots \ldots \ldots \ldots \ldots \ldots \ldots \ldots \ldots \ldots \ldots \ldots \ldots \ldots$

Unconfined Compressive Strength Tests $\ldots \ldots \ldots \ldots \ldots \ldots \ldots . \ldots 4$

Tensile Strength Tests $\quad \ldots \ldots \ldots \ldots \ldots \ldots \ldots \ldots \ldots \ldots \ldots \ldots$

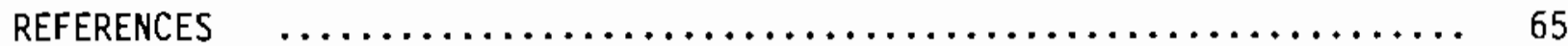

APPENDIX A - PDT-105 STATIC COMPACTION TESTS W/REPEATS $\ldots \ldots \ldots \ldots \ldots \ldots$. 1

APPENDIX B - PRECISION CALCULATION $\ldots \ldots \ldots \ldots \ldots \ldots \ldots \ldots \ldots \ldots \ldots \ldots \ldots \ldots \ldots \ldots \ldots$

APPENDiX $C$ - RANGe PERCENTAge OF MEAN VAlUES MULTI-LAB PRECISION $\ldots \ldots \quad c .1$

APPENDIX D - UNCONFINED COMPRESSIVE TEST RESULTS PROCTOR AND HYDRAULIC STATIC COMPACTION METHODS $\ldots \ldots \ldots \ldots \ldots \ldots \ldots$ D. 1 


\section{FIGURES}

1 Percent Water vs Dry Density for Proctor (Tamping)

Compaction, 1986 ............................... 12

2 Percent Water vs Dry Density Proctor (Tamping) Compaction, 1987

3 Compaction Induced Basalt Particle Breakage, Proctor (Tamping) $\ldots \quad 17$

4 Percent Water vs Dry Density for $75 \%$ Basalt $/ 25 \%$ Bentonite

Mixture Hydraulic Static Compaction, 29,000 Pounds

(2309 psi) Load

5 Percent Water vs Dry Density for $75 \%$ Basalt/25\% Bentonite

Hydraulic Static Compaction, 21,000 Pounds (1672 psi) Load ...... 22

6 Percent Water vs Dry Density for $85 \%$ Basalt/15\% Bentonite, Hydraulic Static Compaction at 29,000 Pounds (2309 psi) Load .... 23

7 Percent Water vs Dry Density for $85 \%$ Basalt/15\% Bentonite, Hydraulic Static Compaction at 21,000 Pounds (1672 psi) Load .... 24

8 Compaction Induced Particle Breakage After Hydraulic Static

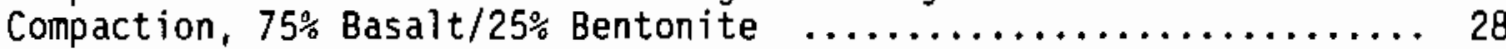

9 Compaction Induced Particle Breakage After Hydraulic Static Compaction (85\% Basa1t/15\% Bentonite)

10 Ultimate Compressive Strength vs Drying Time for Hydraulic Static Compaction Samples at 29,000 1b (2309 psi) Load ......... 34

11 Ultimate Compressive Strength vs Drying Time for Proctor Compaction Samples

12 Stress/Stain Curve (24 hr) Oven Dried Sample, Proctor

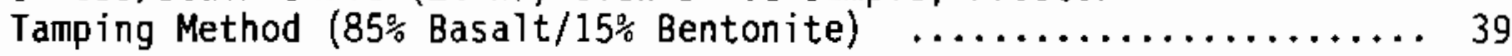

13 Stress/Strain Curve (48 hr) Oven Dried Sample, Proctor Tamping Method ( $85 \%$ Basalt/15\% Bentonite)

14 Stress/Strain Curve Sample (72 hr) Oven Dried Sample, Proctor Tamping Method ( $85 \%$ Basalt $/ 15 \%$ Bentonite) ............ 41

15 Stress/Strain Curve (24 hr) Oven Dried Sample, Hydraulic Static Compaction ( $85 \%$ Basalt/15\% Bentonite)

16 Stress/Strain Curve (48 hr) Oven Dried Sample, Hydraulic Static Compaction ( $85 \%$ Basalt/15\% Bentonite) 
17 Stress/Strain Curve (72 hr) Oven Dried Sample, Hydraulic Static

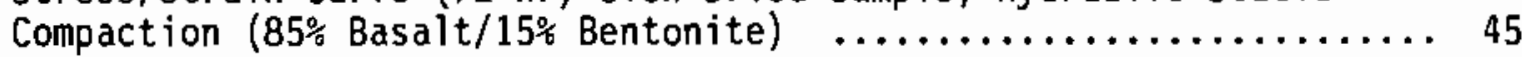

18 Stress/Strain Curve (24 hr) Oven Dried Sample, Hydraulic Static Compaction (75\% Basalt/25\% Bentonite)

19 Stress/Strain Curve (48 hr) Oven Dried Sample, Hydraulic Static Compaction (75\% Basalt/25\% Bentonite) 48

20 Splitting Tensile Strength for $85^{\circ}$ Basalt/15\% Bentonite at $15,920 \mathrm{kPa}$ and $11,530 \mathrm{kPa}$ Compaction Pressures ............ 60 
$\underline{\text { TABLES }}$

1 Typical Sieving Results of Bulk Basalt Material $\ldots \ldots \ldots \ldots \ldots \ldots \ldots$

2 Specific Gravity by Material Size $\ldots \ldots \ldots \ldots \ldots \ldots \ldots \ldots \ldots \ldots$

3 Composite Specific Gravity of Packing Fabrication Mixtures/

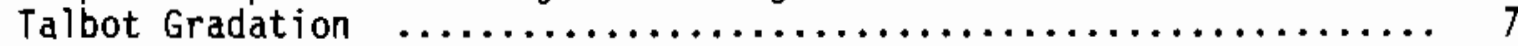

4 Talbot Mix Gradation Percentages $\ldots \ldots \ldots \ldots \ldots \ldots \ldots \ldots \ldots \ldots \ldots$

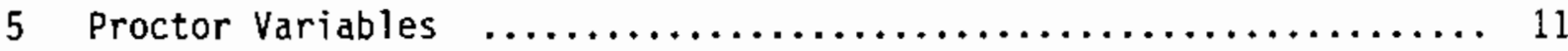

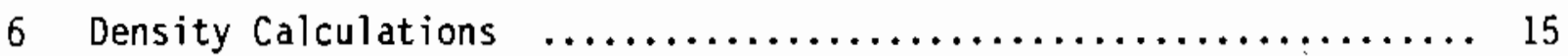

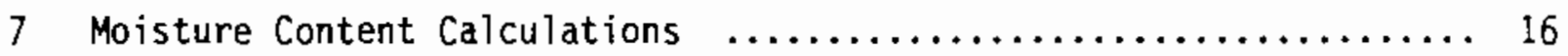

8 Typical Test Matrix for Static Compaction of

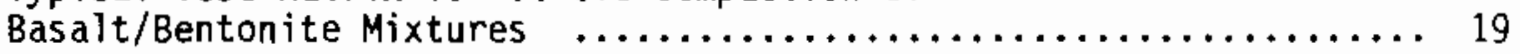

9 Summary of Optimum, Hydraulic Static Compaction Method,

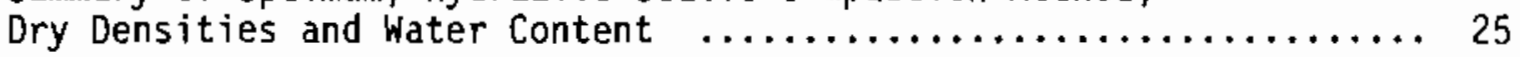

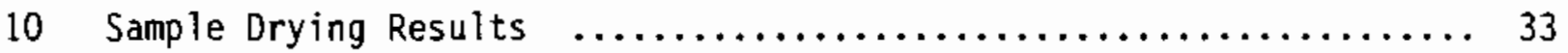

11 Test Matrix for $85 \% / 15 \%$ Mixtures Proctor Method $\ldots \ldots \ldots \ldots \ldots \ldots . \ldots 37$

12 Comparison of Unconfined Compressive Strength

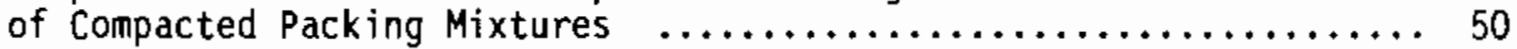

13 Splitting Tensile Strength Test Matrix and Results .......... 61

14 Comparison of Average Splitting Tensile Strength with Compaction Pressure 
FY 87 PACKING FABRICATION TECHNIQUES (COMMERCIAL WASTE FORM) RESULTS

\subsection{INTRODUCTION}

This report encompasses the laboratory-scale investigations of fabrication techniques, using site specific basalt and Wyoming sodium bentonite, to construct a prefabricated packing. The waste package, including the specific packing discussed in this report, is the primary component of the engineered barrier system. As such, the waste package is being developed to satisfy the two major Nuclear Regulatory Commission (NRC) criteria of substantially complete containment for 300 to 1000 years (Technical Issue 1.4, "Substantially Complete Containment") and long-term control of radionuclide release (Technical Issue 1.5, "Gradual Release of Radionuclides from the EBS"). As a major component of the waste package system, the packing is also required to assist in satisfying these two major criteria. The preformed packing or sorbent material currently being considered by the Integrating Contractor (IC), is a Basalt waste Isolation Project (BWIP) waste package subpart which enhances retrievability and encloses the waste container in a diffusion controlled chemical buffer. In addition, the packing system must be durable enough to withstand the manufacturing activities, storage, transportation, and installation with no significant degradation of expected performance. The packing functions may be defined as follows:

1. The waste package packing should minimize container corrosion during the 300 to 1000 years following repository closure, during which substantially complete containment of radionuclides is required. Secondary functions include 1) minimization of groundwater flux past the container, 2) removal of oxygen as a potential corrosive agent, and 3) localization of corrosion products at the packing/container interface.

2. The waste package packing should also prevent transport of radionuclides from the waste package during the 300 to 1000 year containment period in the event of premature container failure. 
3. Following the containment period, the waste package should minimize long-term radionuclide release from the waste package to the host rock. Secondary functions include 1) minimizing mass transport from the waste package to the host rock, 2) establishing and maintaining a waste package groundwater composition that minimizes radionuclide solubility, and 3) maximizing radionuclide sorption.

Thus, the overall purpose of the packing design and development investigation, is to provide specifications for the final waste package components design used for disposal of waste in the repository. This report, herein, discusses the supportive packing information of physical and engineering properties needed to prepare prototypical full-scale prefabricated packing and final specifications.

The major content of this report discusses the principal investigations accomplished during the 1987 fiscal year, however, where appropriate, the FY-86 investigation for reference and background data will be included. These investigations have included preparation of technical procedures and the performance of compaction fabrication tests to evaluate packing dry densities and unconfined compressive strength and the tensile strength of specific basalt/bentonite gradations and mixtures. The Talbot (Talbot 1983) gradation/mix design was the basis and the primary mixture configuration for all the mixtures analyzed. Modifications to the Talbot mix, by the scalp and replace method, were made to provide for mixtures of $85 \%$ basalt $/ 15 \%$ bentonite, $75 \%$ basalt/25\% bentonite and $65 \%$ basalt $/ 35 \%$ bentonite. All of these mixtures were investigated for applicable dry densities, i.e., equal to or greater than $2.0 \mathrm{~g} / \mathrm{cm}^{3}\left(125 \mathrm{lb} / \mathrm{ft}^{3}\right)$. Limited packing/drying techniques and unconfined compressive and tensile strength of the packing were also evaluated.

The intent of this report is to report the technical/laboratory testing findings of the Packing Fabrication Task. For justification of the methods used, the reader(s) should refer to the approved procedures developed for this task (PNL 1987g). 
The principal sections of this report include:

- A description of the packing materials used in this packing development task, i.e., the site specific basalt and the Wyoming bentonite.

- The physical and engineering properties are discussed followed by the results/evaluation of the unconfined compressive strength testing.

- Conclusions are made with regard to the current FY investigations, especially pertinent are the achievement of the minimal dry densities and emergence of the mixture design which produces the highest unconfined compressive and tensile strength.

- Recommendations are made for the follow-on work for the FY 88. 


\subsection{MECHANICAL DEVELOPMENT LABORATORY}

The majority of the laboratory activities including inventory control, sieving, mixing of materials, compaction, physical properties analyses and strength testing, were carried out in Battelle, Pacific Northwest's Mechanical Development Laboratory (MDL) building, 3000 Area, in Richland, Washington. (A minor portion of the physical properties analyses was accomplished in the Battelle Northwest (BNW) Soil Laboratory, Sigma-V Building, Richland, Washington.) 


\subsection{MATERIALS USED FOR TESTING}

\subsection{WHC BASALT/BENTONITE}

\section{1 .1 Basalt}

The basalt material was supplied by the Westinghouse Hanford Company (WHC) from WHC's Maintenance and Transportation waste pile, Gable Mountain Quarry. The Hanford, site specific basalt was supplied in bulk quantities to BNW with applicable aggregate sizes of material meeting U.S. Standard sieve sizes, i.e., minus $3 / 8$ in. and plus $\# 4, \# 8, \# 16, \# 30, \# 50$, \#100, suitable for the Talbot gradation mix design given in Section 4.2.1.

The bulk quantities of basalt were processed and stockpiled into inventories of the required sieve sizes. To assure the quality of the sieving technique and to provide adequate gradation mix inventories, a sieving acceptance criteria (PNL 1987h) was established. An acceptable sieve process, determined by weight, established that a known weight of bulk material must weigh within $2 \%$ of the original weight after passing through the sieves (PNL 1987h). Table 1 shows an example of five random 2000-gram bulk samples using the supplied minus $3 / 8$ basalt mix. The five sieving operations clearly indicate that sieving results do satisfy the acceptance criteria of the sieving procedure (PNL 1987h), i.e., the final net weight of the sieved material is within $2 \%$ of the original weight.

\subsubsection{Bentonite}

The bentonite material was procured offsite by WHC and supplied to PNL in $22.7 \mathrm{~kg}(50 \mathrm{lb})$ or $45.4 \mathrm{~kg}(100 \mathrm{lb})$ sacks. The bentonite is classified as standard sodium bentonite (Baroid National Brand) Wyoming grade, 200 mesh material. 
TABLE 1. Typical Sieving Results of Bulk Basalt Material

\begin{tabular}{|c|c|c|c|c|c|c|}
\hline $\begin{array}{l}\text { Sieve } \\
\text { Size }\end{array}$ & $\begin{array}{l}\text { Weight } \\
\text { Sieve } \\
\text { gram } \\
\end{array}$ & $\begin{array}{l}\text { Weight } \\
\text { Sieve + } \\
\text { Basa]t/g }\end{array}$ & $\begin{array}{l}\text { Weight } \\
\text { Sieve + } \\
\text { Basalt/g }\end{array}$ & $\begin{array}{l}\text { Weight } \\
\text { Sieve }+ \\
\text { Basalt/g }\end{array}$ & $\begin{array}{l}\text { Weight } \\
\text { Sieve + } \\
\text { Basalt/g }\end{array}$ & $\begin{array}{l}\text { Weight } \\
\text { Sieve }+ \\
\text { Basalt/g }\end{array}$ \\
\hline 3/8" & 480.7 & 480.7 & 480.7 & 480.7 & 480.7 & 480.7 \\
\hline 4 & 468.7 & 1502.8 & 1588.1 & 1788.8 & 1371.8 & 1622.1 \\
\hline \# 8 & 371.3 & 948.5 & 925.3 & 822.5 & 965.2 & 834.5 \\
\hline \# 16 & 440.0 & 621.9 & 605.1 & 562.1 & 647.7 & 584.2 \\
\hline \#30 & 312.4 & 381.1 & 369.5 & 351.8 & 401.1 & 381.5 \\
\hline$\# 50$ & 397.3 & 433.1 & 424.3 & 413.1 & 451.5 & 439.3 \\
\hline$\# 100$ & 372.6 & 396.9 & 390.2 & 382.3 & 411.2 & 402.4 \\
\hline$\# 200$ & 299.1 & 321.6 & 314.9 & 308.2 & 308.2 & 326.3 \\
\hline PAN & 285.3 & 339.3 & 327.4 & 316.1 & 364.2 & 354.1 \\
\hline TOTALS & 3427.3 & 5425.9 & 5425.5 & 5425.6 & 5426.2 & 5425.1 \\
\hline \multicolumn{2}{|c|}{ Weight Start } & 2000.0 & 2000.0 & 2000.0 & 2000.0 & 2000.0 \\
\hline \multicolumn{2}{|c|}{ Weight Finish } & 1998.6 & 1998.2 & 1998.3 & 1998.9 & 1997.8 \\
\hline \multicolumn{2}{|c|}{ Required Bias $\leq 2 \%$} & $0.07 \%$ & $0.09 \%$ & $0.09 \%$ & $0.06 \%$ & $0.11 \%$ \\
\hline
\end{tabular}

$1 g=2.205 \times 10^{-3} \mathrm{Jb}$ 


\subsection{PHYSICAL PROPERTIES}

\subsection{SPECIFIC GRAVITY}

Specific gravities (SG) of the packing materials were determined using American Society of Testing Materials Standards, ASTM D-854-83, Standard Test Method for Specific Gravity of Soils. Each sieve size of basalt and the bentonite used in the mixing process was analyzed individually for $S G$ as shown in Table 2 .

TABLE 2. Specific Gravity by Material Size

\begin{tabular}{lc}
\multicolumn{1}{c}{ Material Description } & Specific Gravity \\
Retained \#4 Sieve/Basalt & 2.97 \\
Retained \#8 Sieve/Basalt & 3.00 \\
Retained \#16 Sieve/Basalt & 3.06 \\
Retained \#30 Sieve/Basalt & 3.01 \\
Retained \#50 Sieve/Basalt & 2.98 \\
Retained \#100 Sieve/Basalt & 3.00 \\
Bentonite (all percentages) & 2.66
\end{tabular}

A composite of each packing mixture was calculated (PNL 1987a) using the ASTM D-854-83 weighted average method. Results of calculations are shown in Table 3.

TABLE 3. Composite Specific Gravity of Packing Fabrication Mixtures/Talbot Gradation

\begin{tabular}{l} 
Mixture Description \\
\hline $85 \%$ basalt $/ 15 \%$ bentonite \\
$75 \%$ basalt $/ 25 \%$ bentonite \\
$65 \%$ basalt $/ 35 \%$ bentonite
\end{tabular}
Specific Gravity

2.94

2.91

2.87 


\subsection{AGGREGATE GRADATION}

\subsubsection{The Talbot(2) Mix Design}

The Talbot mix design was used to develop the packing test samples. A basalt only mix, herein called the Talbot mix, is based on Talbot's formula:

$P=(d / D)^{n}$ where: $P=$ percent passing a screen opening of size $d$

$\mathrm{d}=$ sieve opening

$D=$ maximum aggregate size

$\mathrm{n}=0.5$

Calculations (PNL 1986) using the Talbot formula resulted in the aggregate percentages, as shown in Table 4:

TABLE 4. Talbot Mix Gradation Percentages

\begin{tabular}{|c|c|c|}
\hline Sieve Size & Percent Passing & Percent Retained \\
\hline US Sieve $3 / 8$ in. & 100 & 0 \\
\hline US Sieve \#4 & 71 & 29 \\
\hline US Sieve \#8 & 50 & 21 \\
\hline US Sieve $\# 16$ & 35 & 15 \\
\hline US Sieve $\# 30$ & 25 & 10 \\
\hline US Sieve $\# 50$ & 18 & 7 \\
\hline US Sieve $\# 100$ & 13 & 5 \\
\hline US Sieve \#200 & 10 & 3 \\
\hline Pan (retained) & - & 10 \\
\hline Totals & & $100^{\circ}$ \\
\hline
\end{tabular}

\subsection{PACKING MIXTURES}

\subsubsection{Raw Materials Basalt and Bentonite}

Based on the Talbot gradation of Table 4, basalt/bentonite mixtures were developed for use in laboratory tests. The Talbot gradation is used as the base line "idealized" gradation curve. The mixture developed for testing closely approximates the ideal curve when the scalped fines are replaced with 
"equally fine" bentonite. Typically a percentage of the fines, i.e, the smaller sieve size openings and the pan percentage, were scalped and replaced with equal percentages of bentonite. For example a $75 \%$ basalt/25\% bentonite mix would consist of the \#4, \#8, \#16, \#30 percent retained for basalt material, i.e., $29+21+15+10=75 \%$, with the remaining $25 \%$ consisting of bentonite material. The same method was used to generate the other mixtures of $85 \%$ basalt/ $15 \%$ bentonite and $65 \%$ basalt/35\% bentonite. The packing mixture design, described herein, was used in all of the mixture preparation/testing methods, regardless of the compaction method, i.e., Proctor, static plus vibration or the hydraulic static compaction.

\subsubsection{Water Content}

In addition to the raw material (basalt/bentonite) design of the mixtures, the surface water for the basalt and bentonite is required (in percent by weight) to bring the water content to the mixture design level. Samples (taken the day before the actual basalt/bentonite mixing process) were routinely selected from the raw materials for water content analyses. The samples were weighed, oven dried and weighed again to determine the net water by percentage of weight. The basalt normally contained about $1.5 \%$ by weight of water and the bentonite about $6 \%$ to $7 \%$ water by weight. Thus, the total weight of the water already contained in the raw materials could be calculated before mixing the test samples and only the net amount of water needed for the desired mixture was added to the mix material.

\subsubsection{Mellowing of Mixtures}

Mellowing of the mixtures, by definition, is the time interval after initial mixing of the basalt, bentonite and water before compaction. The mellowing time must be of sufficient duration to assure an adequate distribution of the water added to the mixtures, thus assuring minimal dry density variability between samples. Tests were carried out to determine an optimum mellowing time. Mixture analysis tests were conducted at mellowing time intervals 16,24, 32 and 48 hours (PNL 1987c). The 32 hour mellowing time proved to be minimum time required to successfully fulfill the criteria of

water content change, i.e., no change in water content $\pm 2 \%$ from the original 
mix moisture content (ASTM 1987e). Insofar as possible the mixtures (water, bentonite and basalt) were mellowed in sealed containers. The procedure used was to place the mixture in a taped, closed plastic bag. The bag was then placed in a bucket with a gasket lid. Thus evaporation, if any, was minimal. Longer mellowing times such as 40 to 48 hours were also used during test sample preparation; these also provided acceptable test results. 


\subsection{ENGINEERING PROPERTIES}

\subsection{COMPACTION FOR DRY DENSITY}

\subsubsection{Proctor Compaction (Tamping)}

\subsubsection{Proctor Tests}

Proctor tamping/compaction (ASTM 1986c) tests carried out in FY 86 indicate that dry density in excess of $2.0 \mathrm{~g} / \mathrm{cm}^{3}\left(125 \mathrm{lb} / \mathrm{ft}^{3}\right)$ could be achieved. Typical results of 36 tests, 12 each for each mixture, are shown in Figure 1. Optimum curves which indicate that both the $85 \%$ basalt $/ 15 \%$ bentonite and the $75 \%$ basalt/25\% bentonite will produce the required dry density. The tests were performed on samples prepared using the scalping technique noted in Section 4.3.1.

At the start of the work for the fiscal year (1987), additional Proctor tests were carried out to further confirm the 1986 data. The 1987 tests, while producing somewhat different results, indicated a similar pattern. Nine tests were performed. Using mixtures of $85 \%$ basalt $/ 15 \%$ bentonite, $75 \%$ basalt $/ 25 \%$ bentonite and $65 \%$ basalt $/ 35 \%$ bentonite. Three moisture contents were used for each mixture. The following variables shown in Table 5 were used:

TABLE 5. Proctor Variables

\begin{tabular}{c} 
Mixture (ba/be) $\%$ \\
\hline $85 \% / 15 \%$ \\
$75 \% / 25 \%$ \\
$65 \% / 35 \%$
\end{tabular}

Tamping lifts
"Mixed For" Moisture Content

\begin{tabular}{|c|c|c|}
\hline Test \#1 & Test \#2 & Test \#3 \\
\hline $9.0 \%$ & $10.5 \%$ & $13.0 \%$ \\
\hline $9.0 \%$ & $10.5 \%$ & $12.0 \%$ \\
\hline $9.0 \%$ & $10.5 \%$ & $12.0 \%$ \\
\hline 5 & 5 & 5 \\
\hline
\end{tabular}




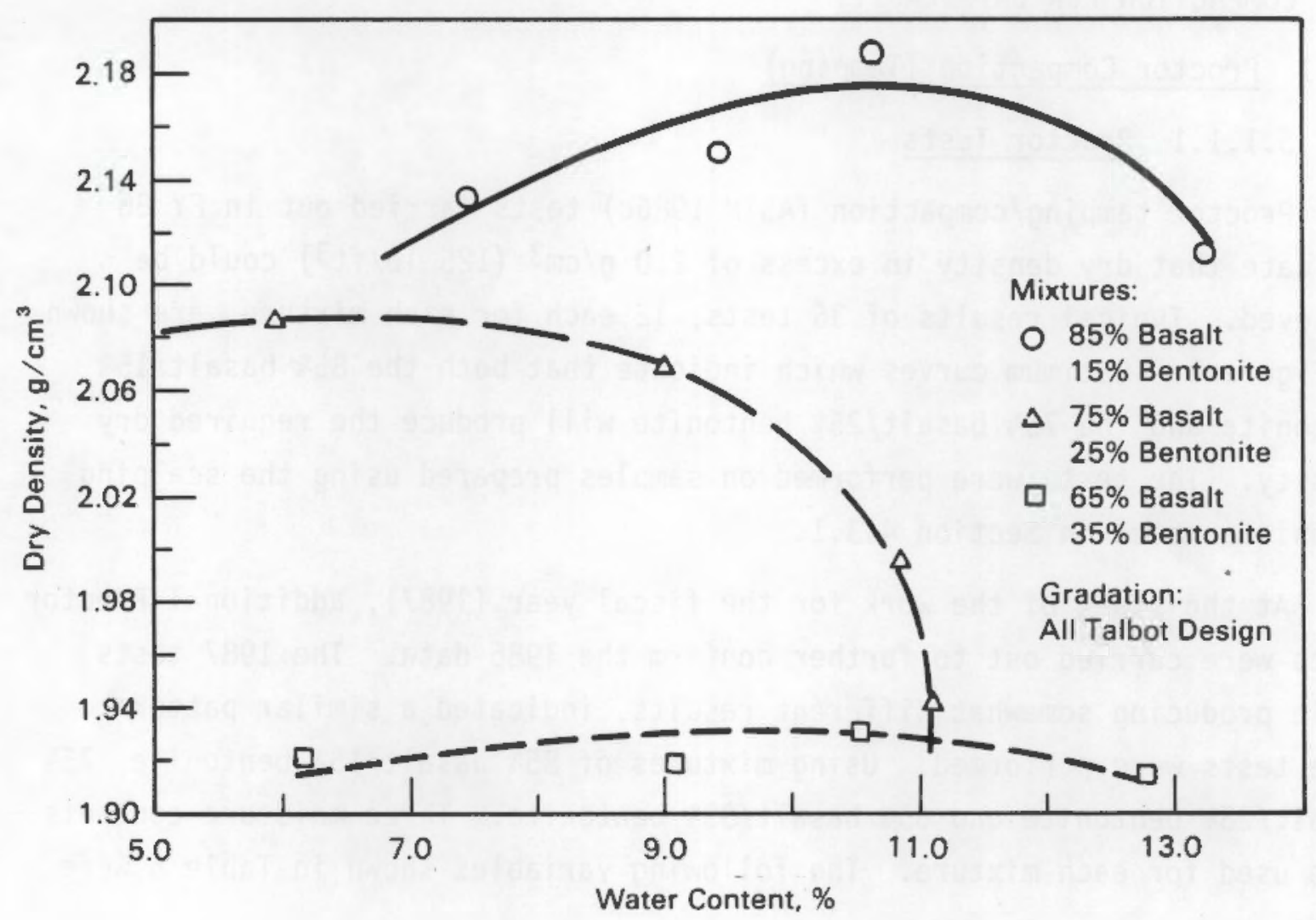

FIGURE 1. Percent Water vs Dry Density for Proctor (Tamping) Compaction, 1986

SI Conversion: $1 \mathrm{~g} / \mathrm{cm}^{3}=62.43 \mathrm{lb} / \mathrm{ft}^{3}$ 
The tests, as shown in Figure 2, show the same general trend of the previous Proctor tamping, i.e., the $85 \%$ basalt/15\% bentonite shows the highest dry density at $2.0 \mathrm{~g} / \mathrm{cm}^{3}\left(125 \mathrm{lb} / \mathrm{ft}^{3}\right)$ to $2.07 \mathrm{~g} / \mathrm{cm}^{3}\left(129 \mathrm{lb} / \mathrm{ft}^{3}\right)$ and that the optimum water content approaches the value of $10.75 \%$. The other mixtures, $75 \%$ basalt $/ 25 \%$ bentonite, also exhibit the same trends as the previous work.

It should be noted that these test samples were mixed for water content without performing a water content analysis of the basalt to determine surface moisture. The rationale at that time was that the basalt would not contain sufficient water to effect the results, especially with the scalping of the basalt fines. Subsequent basalt water content analysis indicated that all particle sizes of the basalt did contain some surface water. Regardless of this the dry density results are consistent. The $10.5 \%$ optimum water is a predictable value for the $85 \%$ basalt $/ 15 \%$ bentonite Proctor tamping tests.

\subsubsection{Analysis of the Samples}

Dry density and water contents of the compacted samples were calculated in accordance with standard ASTM procedures (ASTM 1986c). Calculations tables shown as Table 6 and Table 7 were developed for the Proctor tests. The tables indicate the results of the $85 \%$ basalt $/ 15 \%$ bentonite composite Proctor tamping tests, i.e., as shown in Figure 2. These calculations are typical of all the Proctor compaction results.

\subsubsection{Particle Breakage Induced by Proctor (Tamping)}

Basalt particle breakage was induced by the Proctor compaction process. A composite graphic of the compaction breakage is shown in Figure 3 . The percentages shown for the breakage are the composite of fifteen sievings after tamping. The Talbot mix gradation is shown for comparison. The tamping of the samples indicates about a $7 \%$ to $10 \%$ addition breakage in the larger particles; the smaller particles indicate about a 2 to $3 \%$ additional breakage. (Although not a prime concern for these investigations the additional breakage produced during the compaction process does become a concern in the full-scale packing fabrication. The compaction process chosen 
should not produce a high breakage because the additional breakage will result in changes to the gradation curve, i.e, less dry density and the optimum moisture content point. Future investigations should determine what minimal breakage percentages are acceptable.)

\subsubsection{Vibration Plus Static Load Compaction}

Compaction by vibration is a recognized ASTM method (ASTM 1986a) for determining the density of soils. Therefore, a decision was made to investigate vibration plus static load as a viable compaction method. A vibration table and controlling apparatus was installed and calibrated (Kaufman 1979) and set up to carry out qualification tests to determine a useful vibration compaction test matrix, i.e., a matrix of compaction time, lifts, static load, etc. Results of these tests are discussed below.

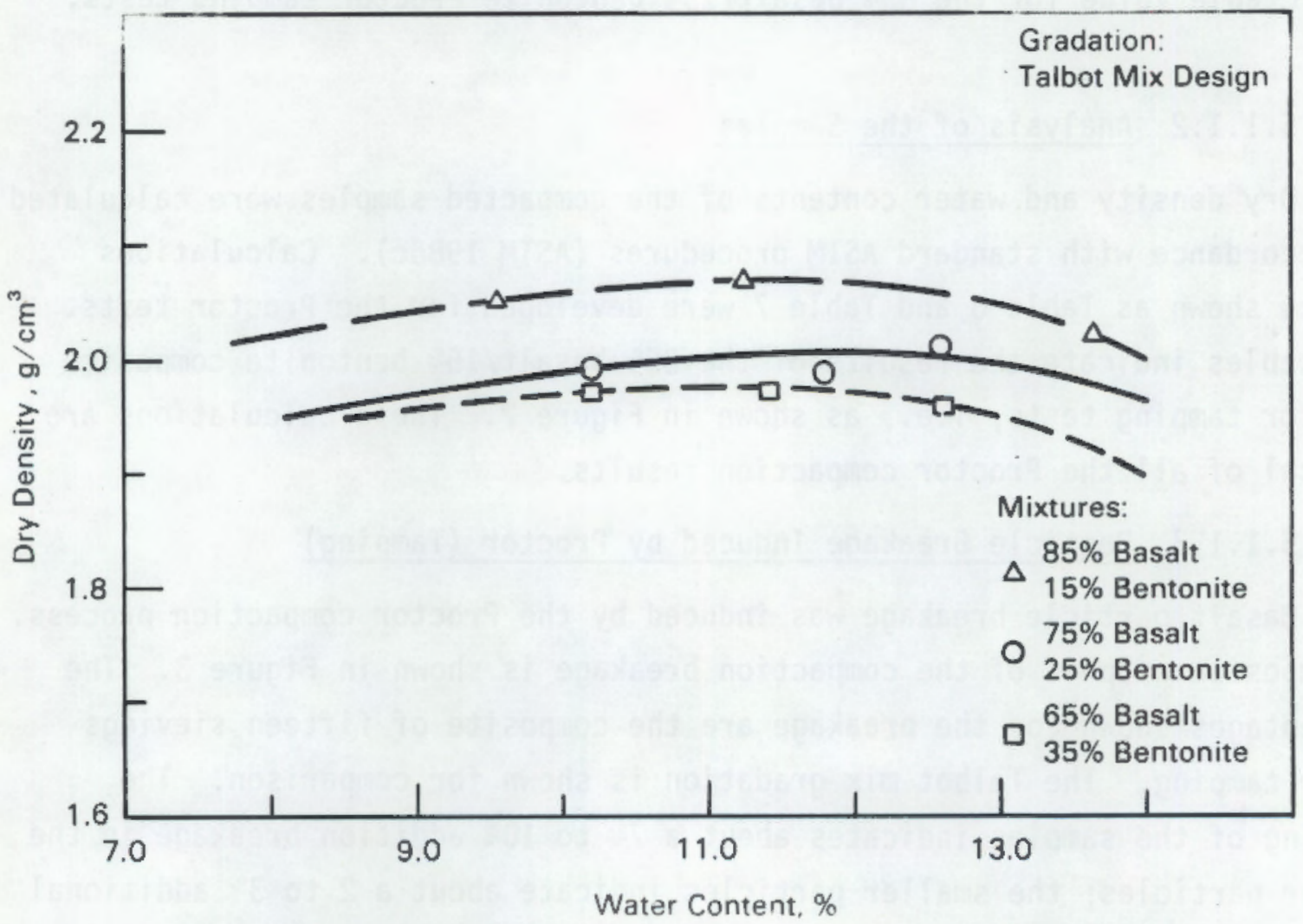

FIGURE 2. Percent Water vs Dry Density for Proctor (Tamping) Compaction, 1987 SI Conversion: $1 \mathrm{~g} / \mathrm{cm}^{3}=62.43 \mathrm{lb} / \mathrm{ft}^{3}$ 
TABLE 6. Typical Dry Density Calculations (ASTM 1987d) COMPACTION TEST

TEST TYPE: PDT-103 TAMPING

SAMPLE MIX RATIO: $85 \% \mathrm{Ba} / 15 \%$ Be TALBOT MIX

SAMPLE NO.: $1 a, b, c$ (ref. Prac \#14 LRB 5 1918)

SPECIFIC GRAVITY: 2.94
TEST NO.: 1

DATE: $\quad 1-30-87$

TEST BY: KSC

MOLD: VOLUME $1 / 30 \mathrm{ft}^{3}$

WEIGHT $9.449 \mathrm{lb}$

MELLOWING TIME: Sample $\mathrm{a}=45$ hours

Sample b $=46$ hours

Sample $c=46$ hours

DENSITY

Sample 1a

$1 \mathrm{~b}$

1c

\begin{tabular}{|c|c|c|c|c|c|c|}
\hline DETERMINATION NO. & 1 & 2 & 3 & 4 & 5 & 6 \\
\hline $\begin{array}{l}\text { WT. MOLD + COM- } \\
\text { PACTED SOIL, Ib }\end{array}$ & 14.11 & 14.24 & 14.23 & & & \\
\hline WT. MOLD, Ib & 9,449 & 9.449 & 9.449 & & & \\
\hline $\begin{array}{l}\text { WT. COMPACTED } \\
\text { SOIL, } 1 \mathrm{~b}\end{array}$ & 4.661 & 4.791 & 4.781 & & & \\
\hline $\begin{array}{l}\text { WET DENSITY, } \gamma_{m} \\
\left(1 \mathrm{~b} / \mathrm{ft}^{3}\right)\end{array}$ & 139.97 & 143.87 & 143.57 & & & \\
\hline $\begin{array}{l}\text { DRY DENSITY, } \gamma d \\
\left(1 \mathrm{~b} / \mathrm{ft}^{3}\right)\end{array}$ & 127.76 & 129.34 & 126.34 & & & \\
\hline $\begin{array}{l}\text { DRY DENSITY, } \gamma d \\
\text { grams } / \mathrm{cm}^{3}\end{array}$ & 2.05 & 2.07 & 2.02 & & & \\
\hline
\end{tabular}


TABLE 7. Typical Moisture Content Calculations

TEST N0. 1 Talbot Mix $85 \%$ basalt $/ 15 \%$ bentonite

MOISTURE CONTENT Sample la la 1c

\begin{tabular}{|l|c|c|c|c|c|c|}
\hline DETERMINATION NO. & 1 & 2 & 3 & 4 & 5 & 6 \\
\hline $\begin{array}{l}\text { CONTAINER NO. } \\
\text { "C" }\end{array}$ & \multicolumn{1}{c|}{ "D" } & "E" & & & \\
\hline $\begin{array}{l}\text { WT. CONTAINER + } \\
\text { WET SOIL, g }\end{array}$ & 201.9 & 248.6 & 250.6 & & & \\
\hline $\begin{array}{l}\text { WT. CONTAINER + } \\
\text { DRY SOIL, g }\end{array}$ & 194.0 & 235.0 & 234.1 & & & \\
\hline WT. WATER Ww, g & 7.9 & 13.6 & 16.5 & & & \\
\hline WT. CONTAINER, g & 111.4 & 113.9 & 113.1 & & & \\
\hline WT. DRY SOIL, WS, g & 82.6 & 121.1 & 121.0 & & & \\
\hline WATER CONTENT, W, \% & 9.56 & 11.23 & 13.64 & & & \\
\hline
\end{tabular}




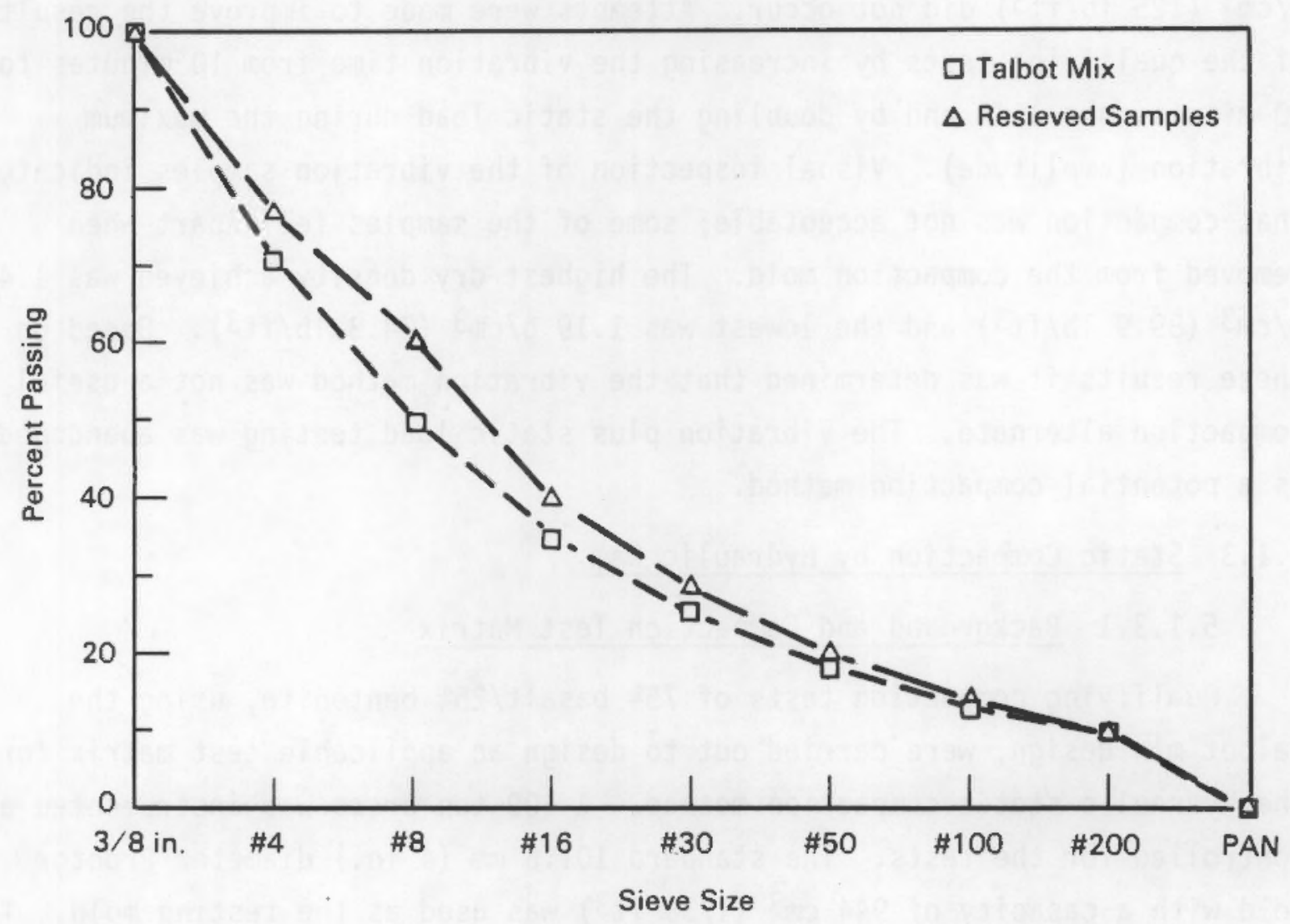

FIGURE 3. Compaction Induced Basalt Particle Breakage After Proctor (Tamping) 


\subsubsection{Vibration Plus Static Load Tests}

A number of vibration tests were carried out, however, none of the tests were successful, i.e., satisfactory compaction of the mixtures to the 2.0 $\mathrm{g} / \mathrm{cm}^{3}\left(125 \mathrm{lb} / \mathrm{ft}^{3}\right)$ did not occur. Attempts were made to improve the results of the qualifying tests by increasing the vibration time from 10 minutes to 30 minutes per lift and by doubling the static load during the maximum vibration (amplitude). Visual inspection of the vibration samples indicated that compaction was not acceptable; some of the samples fell apart when removed from the compaction mold. The highest dry density achieved was 1.44 $\mathrm{g} / \mathrm{cm}^{3}\left(89.9 \mathrm{lb} / \mathrm{ft}^{3}\right)$ and the lowest was $1.19 \mathrm{~g} / \mathrm{cm}^{3}\left(74.3 \mathrm{lb} / \mathrm{ft}^{3}\right)$. Based on these results it was determined that the vibration method was not a useful compaction alternate. The vibration plus static load testing was abandoned as a potential compaction method.

\subsubsection{Static Compaction by Hydraulic Ram}

\subsubsection{Background and Compaction Test Matrix}

Qualifying compaction tests of $75 \%$ basalt $/ 25 \%$ bentonite, using the Talbot mix design, were carried out to design an applicable test matrix for the hydraulic static compaction method. A 100-ton press was instrumented and controlled for the tests. The standard $101.6 \mathrm{~mm}$ (4 in.) diameter Proctor mold with a capacity of $944 \mathrm{~cm}^{3}\left(1 / 30 \mathrm{ft}^{3}\right)$ was used as the testing mold. The tests indicated that the variables of time and lift could be held constant throughout all of the compaction tests. Static pressure loads of $15,920 \mathrm{kPa}$ (2309 psi) maximum, at $13,150 \mathrm{kgs}(29,000 \mathrm{lb})$ force, and $11,530 \mathrm{kPa}(1672$ psi) minimum, at $9524 \mathrm{kgs}(21,000 \mathrm{lb})$ force, on the 4 -in. mold area, proved to be sufficient to compact the material to the required $2.0 \mathrm{~g} / \mathrm{cm}^{3}(125$ $\left.\mathrm{lb} / \mathrm{ft}^{3}\right)$ density, i.e., densities of $2.05\left(128 \mathrm{lb} / \mathrm{ft}^{3}\right)$ to $2.14 \mathrm{~g} / \mathrm{cm}^{3}(134$ $\mathrm{lb} / \mathrm{ft}^{3}$ ) were achieved in the qualifying tests.

After the qualification tests were completed, a detailed test matrix was developed for the static compaction tests. Four variables of water content 
were chosen for the compaction tests. These were, $8.5 \%, 10.0 \%, 11.5 \%$, and $13.0 \%$. For clarification, a portion of the test matrix (PNL 1987i) is shown in Table 8.

TABLE 8. Typical Test Matrix for Static Compaction of Basalt/Bentonite Mixtures

Constant load tests (maximum load)

$\begin{array}{llllll}\text { Load } & 29,000 \mathrm{lb} & 29,000 \mathrm{lb} & 29,000 \mathrm{lb} & 29,000 \mathrm{lb} \\ \text { Lifts } & 2 & 2 & 2 & 2 \\ \text { Water } & 8.5 \% & 10 \% & 11.5 \% & 13.0 \% \\ \text { Time } & 5 \text { minutes } & 5 \text { minutes } & 5 \text { minutes } & 5 \text { minutes } \\ \text { No. Tests } & 3 & 3 & 3 & 3\end{array}$

Constant load tests (minimum load)

$\begin{array}{llllll}\text { Load } & 21,000 \mathrm{lb} & 21,000 \mathrm{lb} & 21,000 \mathrm{lb} & 21,000 \mathrm{lb} \\ \text { Lifts } & 2 & 2 & 2 & 2 \\ \text { Water } & 8.5 \% & 10 \% & 11.5 \% & 13.0 \% \\ \text { Time } & 5 \text { minutes } & 5 \text { minutes } & 5 \text { minutes } & 5 \text { minutes } \\ \text { No. Tests } & 3 & 3 & 3 & 3\end{array}$

Test matrix for $15 \%$ bentonite $/ 85 \%$ basalt mixture

\begin{tabular}{|c|c|c|c|c|c|c|}
\hline Load & $29,000 \mathrm{lb}$ & $29,000 \mathrm{lb}$ & $29,000 \mathrm{lb}$ & 21,000 & $21,000 \quad 1 b$ & $21,000 \mathrm{Ib}$ \\
\hline Lifts & 2 & 2 & 2 & 2 & 2 & 2 \\
\hline Water & $8.5 \%$ & $9.5 \%$ & $13.0 \%$ & $8.5 \%$ & $10.8 \%$ & $13.0 \%$ \\
\hline Time & $5 \mathrm{~min}$ & $5 \mathrm{~min}$ & $5 \mathrm{~min}$ & $5 \mathrm{~min}$ & $5 \mathrm{~min}$ & $5 \mathrm{~min}$ \\
\hline No. Tests & s 3 & 3 & 3 & 3 & 3 & 3 Total 18 \\
\hline
\end{tabular}

\subsubsection{Hydraulic Static Compaction Testing for Moisture/Density Relationships}

Sixty hydraulic load, static, compaction tests were carried out using the basalt/bentonite material. The mixing and mellowing techniques and 
Talbot gradations, that were used in the Proctor tests were repeated for the hydraulic compaction tests. The results of the compaction tests are shown in Appendix $A$ of this report. The readers' attention is called to the column entitled Density Dry $\left(\mathrm{g} / \mathrm{cm}^{3}\right)$ of Appendix $A_{i}$ significantly all of the densities noted are above the minimum required, i.e., $2.0 \mathrm{~g} / \mathrm{cm}^{3}\left(125 \mathrm{lb} / \mathrm{ft}^{3}\right)$. The lowest density $2.04 \mathrm{~g} / \mathrm{cm}^{3}\left(127 \mathrm{lb} / \mathrm{ft}^{3}\right)$ was achieved with the hydraulic compaction method of $65 \%$ basalt/35\% bentonite at $11,530 \mathrm{kPa}(1672 \mathrm{psi}$ ) and the highest $2.20 \mathrm{~g} / \mathrm{cm}^{3}\left(137 \mathrm{lb} / \mathrm{ft}^{3}\right)$ occurred in compaction of the $85 \%$ basalt/15\% bentonite at $13,725 \mathrm{kPa}(1990 \mathrm{psi})$. The latter high density was achieved using 4 lifts with a compaction time of 30 minutes for each lift. This was a "random" test for middle load and long compaction time and run for control purposes. It is not considered an indication of an acceptable high production packing technique. Yet, the $85 \%$ basalt/15\% bentonite mixture for the static compaction method does appear to be a promising design/method of achieving acceptable densities. The design/method also indicates a trend that mixture designs with less bentonite and less water tend to develop higher dry densities.

\subsubsection{Dry Density vs Water Content}

Curves were prepared for the hydraulic static compaction tests. Figures $4,5,6$ and 7 were developed from the tests as shown in the matrix of Table-8. The curves were generated using the recommended methods of the ASTM Standards (ASTM 1986b) and as described in BNW procedures (PNL 1987e).

The graphics shown in Figure 4 indicate an optimum dry density of 2.18 $\mathrm{g} / \mathrm{cm}^{3}\left(136 \mathrm{lb} / \mathrm{ft}^{3}\right)$ may be achieved using an optimum water content of $10.0 \%$. Figures 5, 6 and 7 are analogous graphics indicating optimum dry densities and water content for the mixtures tested. Table 9, Summary of Optimum, Hydraulic Static Compaction Method, Dry Densities and Water Content, 1ists the highest to the lowest results shown in Figures 4 through 7. 


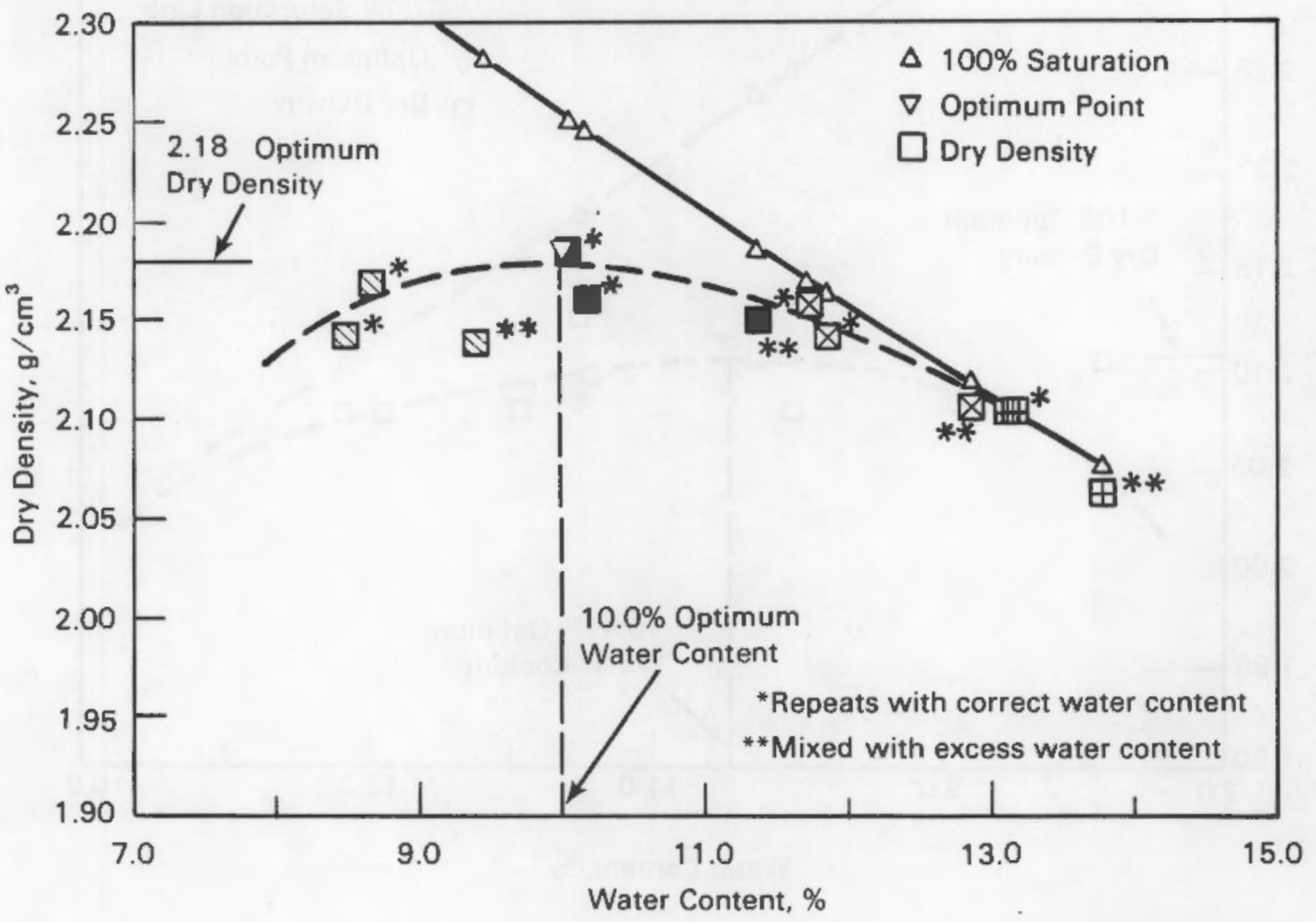

FIGURE 4. Percent Water vs Dry Density for $75 \%$ Basalt/ $25 \%$ Bentonite Mixture, Hydraulic Static Compaction at 29,000 lbs (2309 psi) Load

SI Conversion $1 \mathrm{~g} / \mathrm{cm}^{3}=62.43 \mathrm{lb} / \mathrm{ft}^{3}$ 


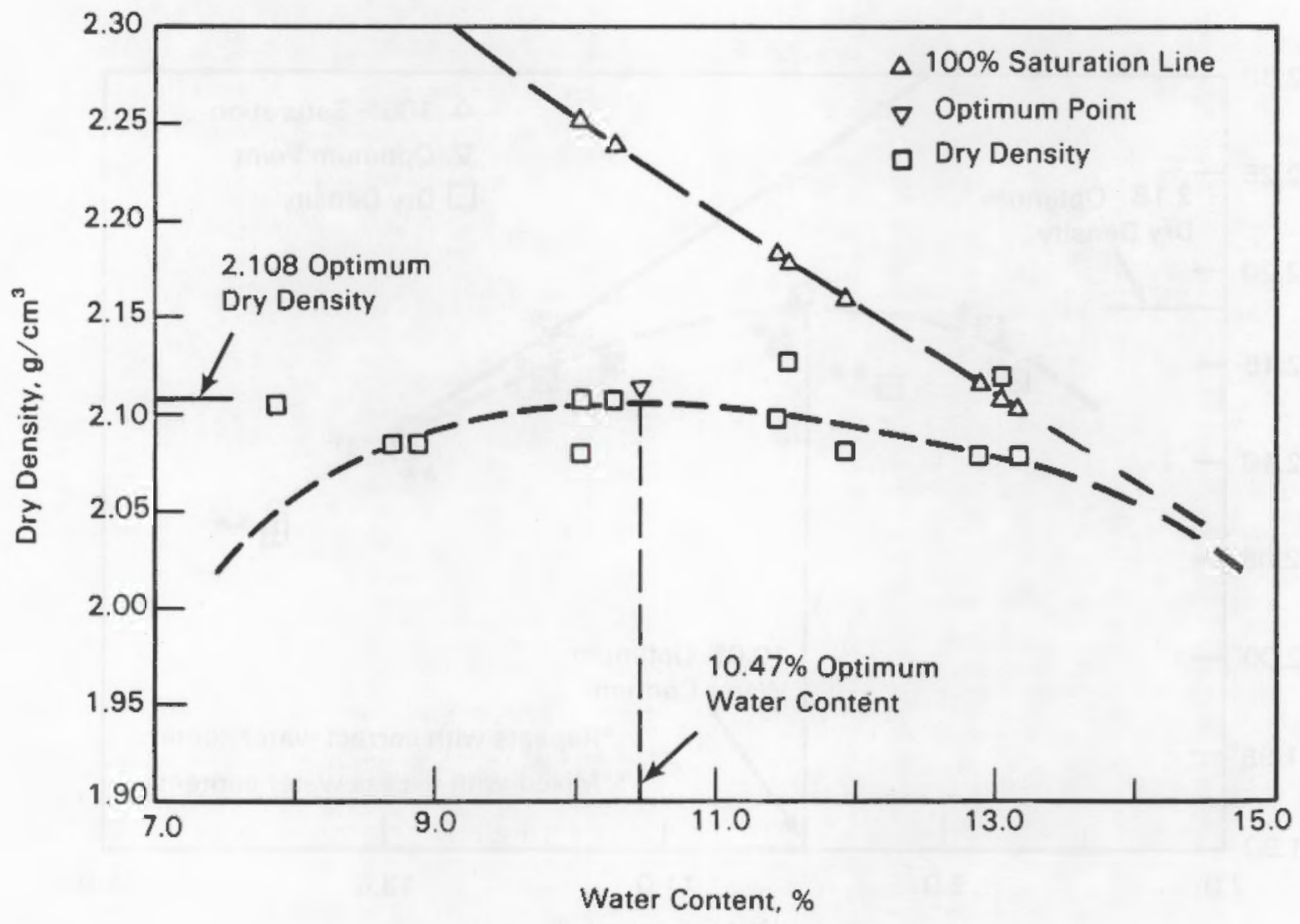

FIGURE 5. Percent Water vs Dry Density for $75 \%$ Basalt/ Bentonite Mixture, Hydraulic Static Compaction, 21,000 lbs (1672 psi) Load

SI Conversion: $1 \mathrm{~g} / \mathrm{cm}^{3}=62.43 \mathrm{lb} / \mathrm{ft}^{3}$ 


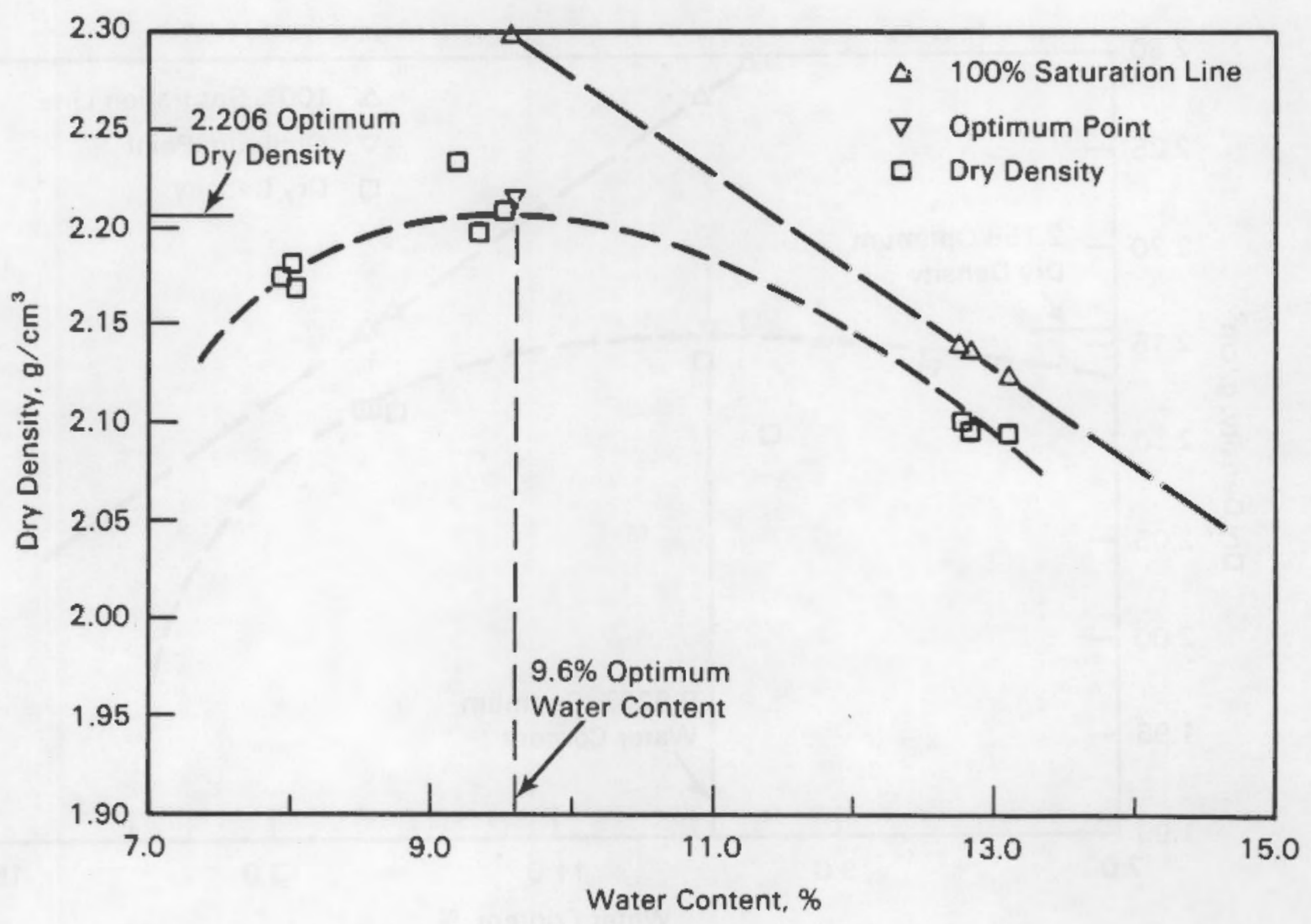

FIGURE 6. Percent Water vs Dry Density for $85 \%$ Basalt/ $15 \%$ Bentonite Mixture, Hydraulic Static Compaction 29,000 lbs (2309 psi) Load

SI Conversion: $1 \mathrm{~g} / \mathrm{cm}^{3}=62.43 \mathrm{lb} / \mathrm{ft}^{3}$ 


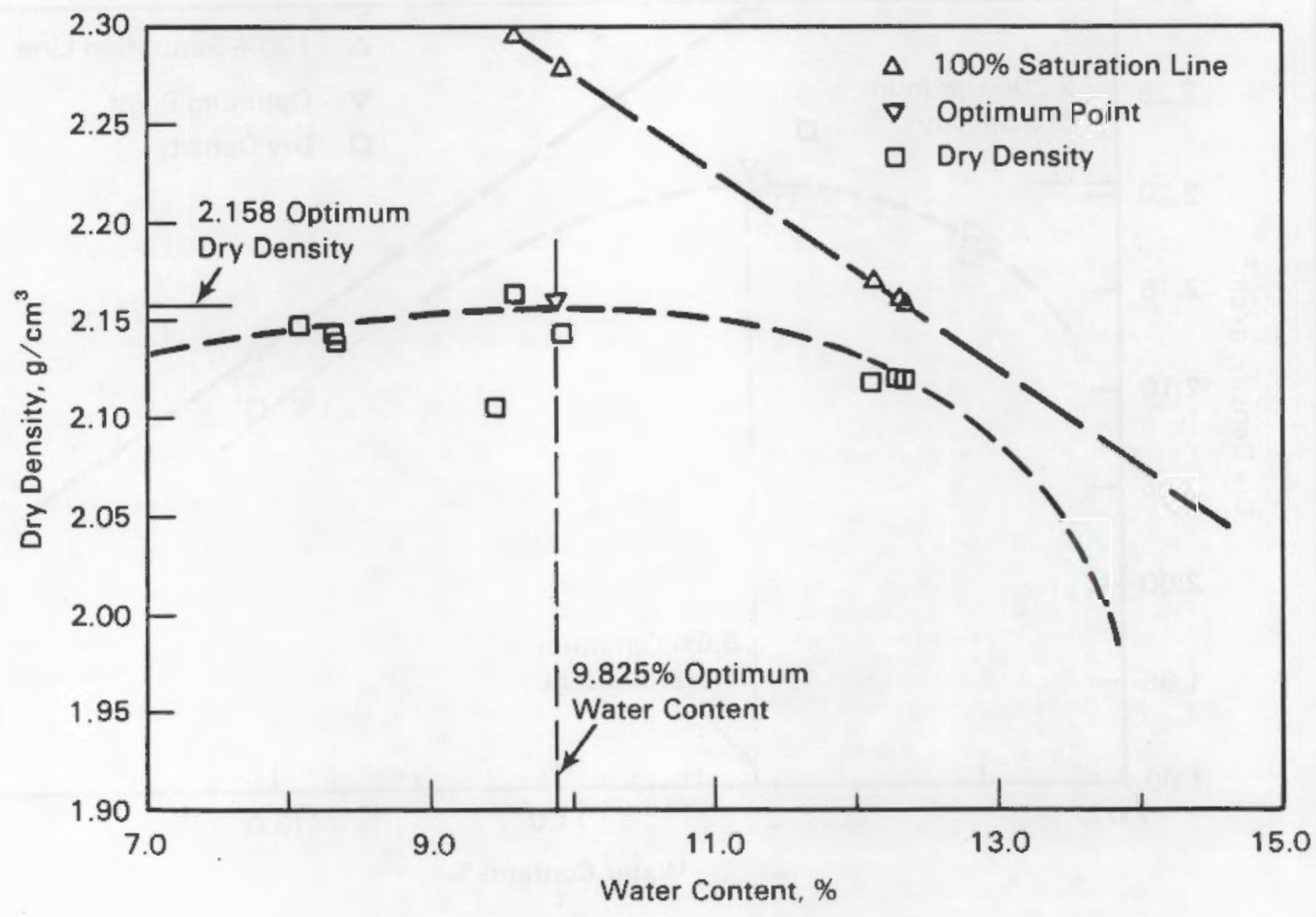

FIGURE 7. Percent Water vs Dry Density for $85 \%$ Basalt/ $15 \%$ Bentonite Mixture, Hydraulic Static Compaction at 21,000 (1672 psi) Load

SI Conversion: $1 \mathrm{~g} / \mathrm{cm}^{3}=62.43 \mathrm{lb} / \mathrm{ft}^{3}$ 
TABLE 9. Summary of Optimum, Hydraulic Static Compaction Method, Dry Densities and Water Content

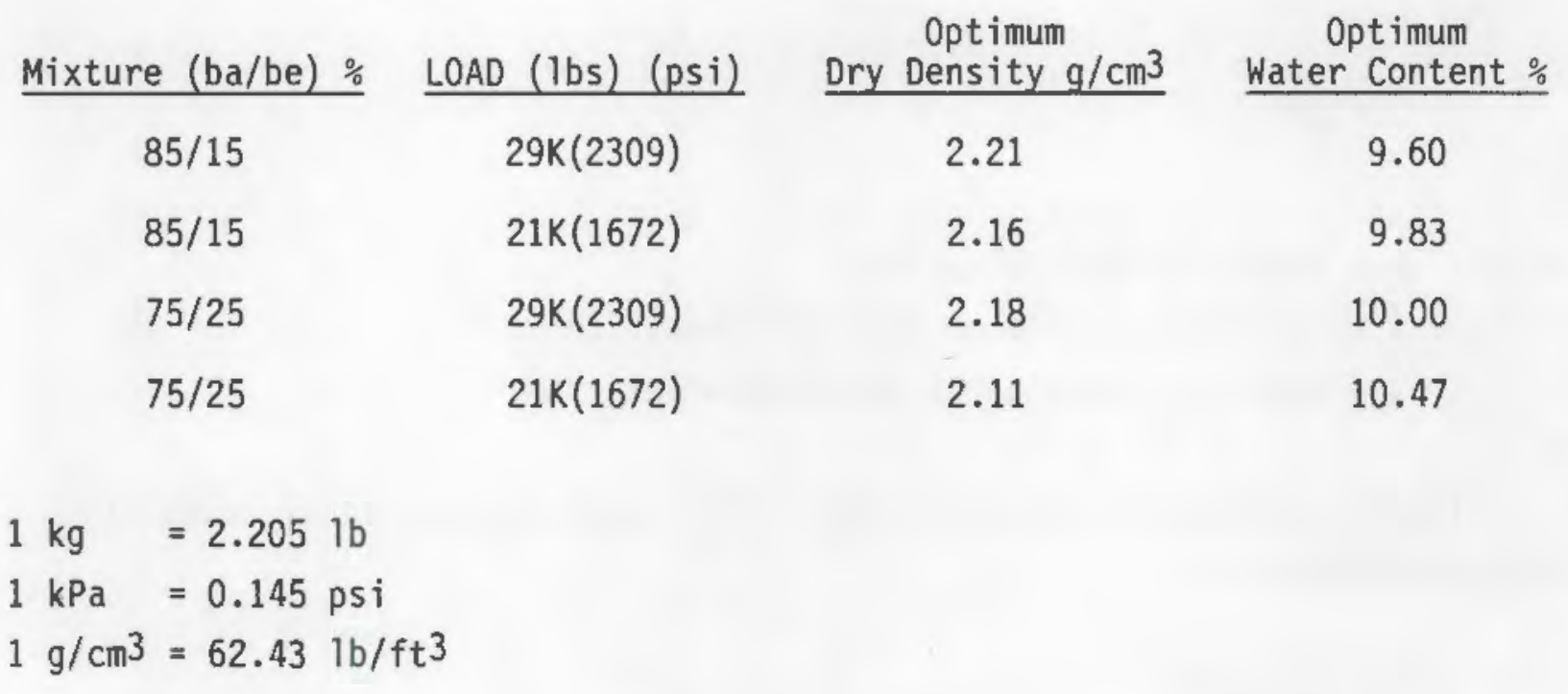

\subsubsection{Precision of Compaction Results.}

Appendix $\mathrm{B}$ and $\mathrm{C}$ contain precision calculations for all the compaction tests. Calculations (PNL 1987b) were performed to determine the acceptability and correlation with ASTM Standards (ASTM 1986b) for the compaction results. The precision requirements of the ASTM Standard (ASTM 1986b) establishes a criteria for judging the acceptability of the dry density and moisture content test results. The criteria are value limits with respect to the standard deviation and percentages of the test mean values. The referenced ASTM Standard (ASTM 1986b) does not establish a criteria for the "single-operator precision" for the Standard Deviation, i.e., assigned values are not available at the present time for this Standard. Rather than ignore the Standard Deviation precision evaluation for this report, BNW chose to use the "multilaboratory precision" as presented in the referenced Standard (ASTM 1986b).(a) Thus, the following discussions

(a) In addition, the work performed by BNW during FY 86 (by a different technical team than used in the FY 87 investigation) may be considered as a separate laboratory result, i.e., a multilab investigation exists. 
are based on the multilaboratory precision values of the referenced Standard (ASTM 1986b). The standard deviation for the test was calculated from the formula (PNL 1987c):

$$
s^{2}=\frac{1}{n-1} \sum_{1}^{n}(x-\bar{x})^{2}
$$

where: $\mathbf{n}=$ number of determinations

$x=$ individual value of each determination

$\bar{x}=$ numerical average of the determinations

The percentages of the mean value limits were determined by calculating a percent based on:

$\% d / W=\frac{\left(T_{l}-T_{s}\right)(100)}{M V}$ (either dry density or water content)

where: $T_{\ell}=$ largest test result

MV = mean value (water or density)

$\mathrm{T}_{\mathbf{s}} \quad$ = smallest test result

$\% d / w=$ Percent of mean value

Results in Appendix $B$ indicate that, for each series of hydraulic static compaction tests, an acceptable repeatability may be achieved for similar or like tests, i.e., those of the same Talbot material/water mix and compacted at the same time, lift and load.

The standard deviation is shown for each test as SQ.RT. SUM/2. For example, see test "Precision Calc. 205-B1 at the upper left corner of Page 8.2. The SQ.RT. SUM/2 is the standard deviation for the Dry Density and Moisture Content. The allowable Precision (ASTM 1986b) limits for the standard deviation is \pm 1.66 for Maximum Density and \pm 0.86 for Optimum Moisture Content. Note that in the 205-81 test the precision values shown 
are well within the allowable limits. All of the standard deviation values shown for all tests are within these limits.

Reference ASTM (1986b) also defines the allowable limits of testing results as expressed in "acceptable range of two results, expressed as a percent of mean value." The tests were examined/analyzed for acceptability of the percentage criteria. Results of these calculations are shown in Appendix C. Again using 205-B1 as an example, see Page C.1, left column, third down for the precision results of this test. The average for all three tests, the largest (range) difference between any two results and the magnitude of the difference, is shown for the tests with respect to dry density and moisture content. For the referenced test the average of the dry density is 2.091766 (a) $\mathrm{g} / \mathrm{cm}^{3}\left(131 \mathrm{lb} / \mathrm{ft}^{3}\right)$; the largest difference between any two dry densities is $0.0208 \mathrm{~g} / \mathrm{cm}^{3}$. The difference expressed as a percentage is shown below:

$$
\frac{0.0208(100)}{2.091766}=0.9944 \% \text { Allowable } \text { (ASTM 1986b) }^{\text {A }}=4 \%
$$

A similar expression may be shown for the moisture content:

$$
\frac{1.01(100)}{8.479033}=11.91 \% \text { Allowable }{ }^{\text {(ASTM 1986b) }}=15 \%
$$

All of the percentages shown in Appendix $C$ indicate percentages, $<4 \%$ for dry density and $<15 \%$ for moisture content.

\subsubsection{Particle Breakage Induced by Hydraulic Compaction Methods}

Particle breakage was also induced by the hydraulic static compaction process. The graphics of Figures 8 and 9 show the particle breakage.

Figure 8 shows a comparison of particle breakage between the loads of $13,150 \mathrm{kgs}(29,000 \mathrm{lbs})$ and $9524 \mathrm{kgs}(21,000 \mathrm{lbs})$ for $75 \%$ basalt $/ 25 \%$ bentonite mixtures. The percent passing after compaction is plotted against

(a) The 6 decimal accuracy as shown is produced by Lotus spread sheet calculations. For consistency, the examples are shown as reported in the appendix(es). 


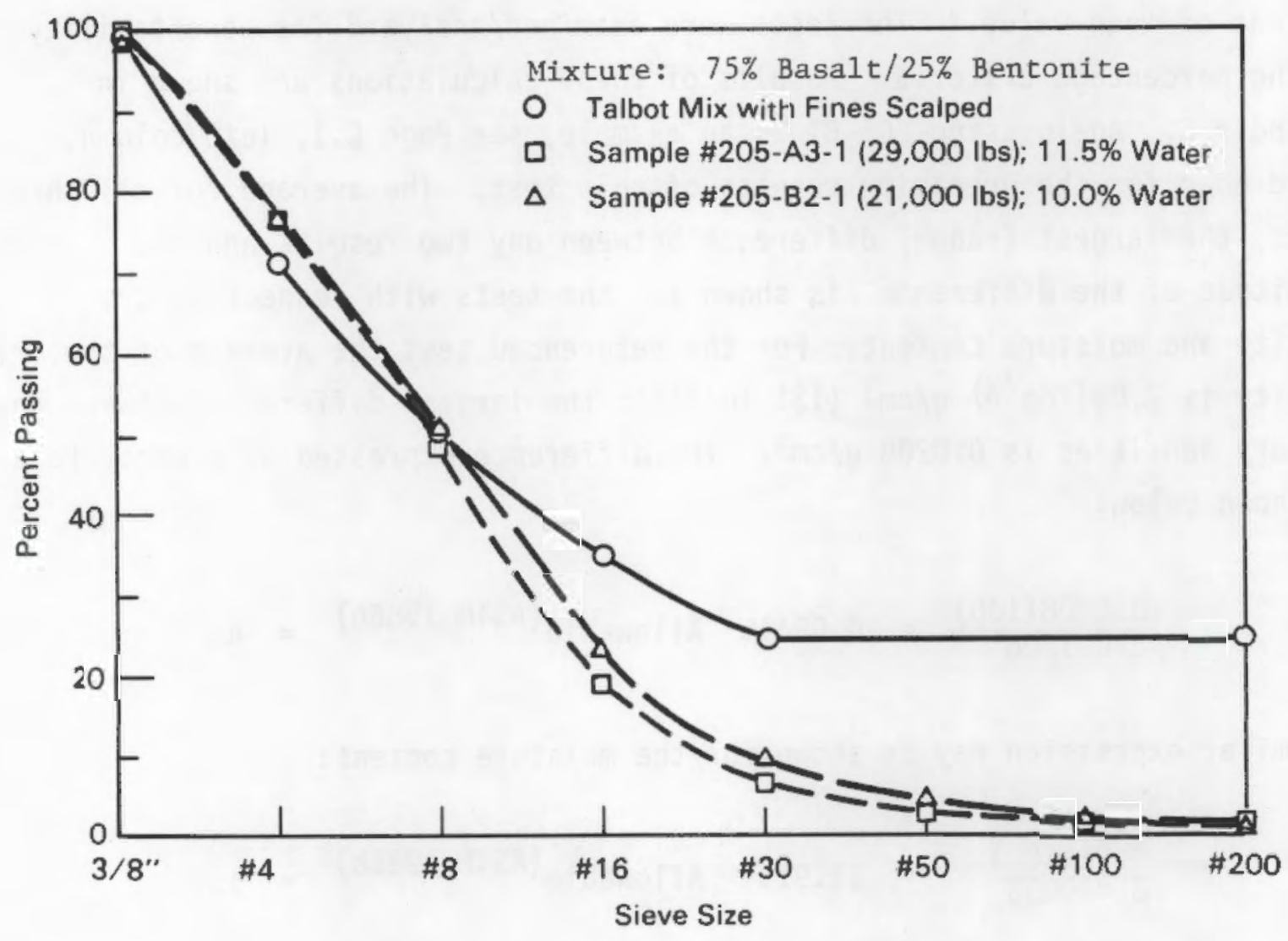

FIGURE 8. Compaction Induced Particle Breakage After Hydraulic Static Compaction, $75 \%$ Basalt/ $25 \%$ Bentonite Mixture

SI Conversion $2.2 \mathrm{kgs}-1 \mathrm{lb}$ 


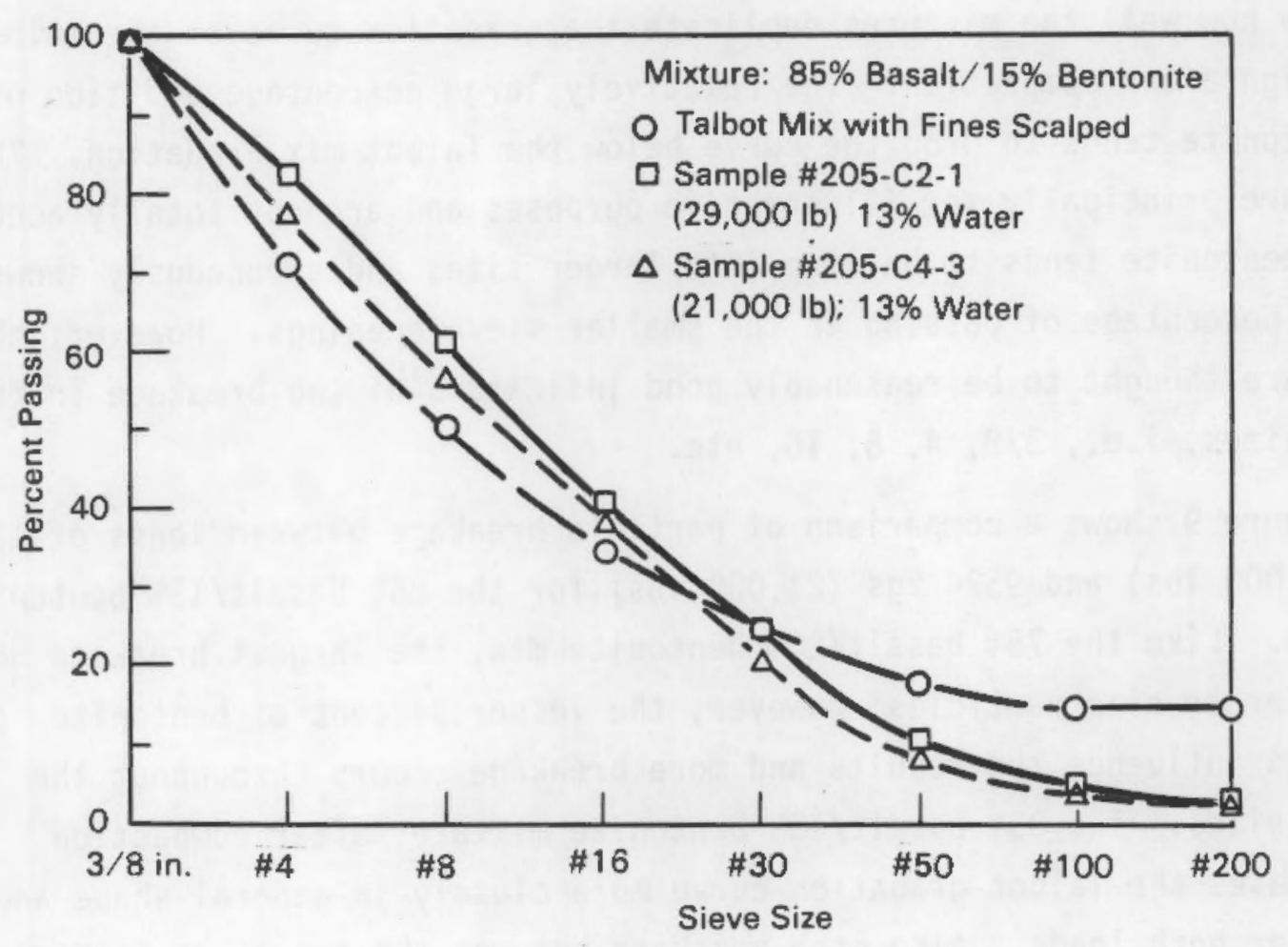

FIGURE 9. Compaction Induced Particle Breakage After Hydraulic Static Compaction $85 \%$ Basalt/15\% Bentonite Mixture

SI Conversion: $2.2 \mathrm{kgs}=1 \mathrm{lb}$ 
the Talbot gradation. For the $75 \%$ basalt $/ 25 \%$ bentonite, the curves for breakage are essentially the same for both compaction loads. The consistence of the curve's slope(s) may be attributed to the similarity of the mixtures. As expected, the greatest breakage occurs in the larger size, i.e., 5 to $6 \%$ in the \#4 size sieve and 1 or $2 \%$ in the \#8 size sieve. The curves also indicate how well the mixtures duplicate the gradation curve of the Talbot mix design after compaction. The relatively large percentage addition of the $25 \%$ bentonite tends to drop the curve below the Talbot mix gradation. The curves are principally for illustrative purposes and are not totally accurate as the bentonite tends to ball up into larger sizes and erroneously shows a smaller percentage of passing in the smaller sieve openings. However, the curves are thought to be reasonably good indicators of the breakage in the larger sizes, i.e., $3 / 8,4,8,16$, etc.

Figure 9 shows a comparison of particle breakage between loads of 13,150 kgs $(29,000 \mathrm{lbs})$ and $9524 \mathrm{kgs}(21,000 \mathrm{lbs})$ for the $85 \%$ basalt $/ 15 \%$ bentonite mixtures. Like the $75 \%$ basalt $/ 25 \%$ bentonite mix, the largest breakage occurs in the larger size particles; however, the lesser percent of bentonite, at $15 \%$, does influence the results and more breakage occurs throughout the various sizes. The $85 \%$ basalt $/ 15 \%$ bentonite mixture, after compaction, approximates the Talbot gradation curve more closely in general shape and design for both loads. Also, the breakage between the two loads is more consistent with respect to expected results, i.e., the highest load resulted in the highest percent of breakage. Good correlation to the shape and design of the Talbot gradation is more apparent in the $85 \%$ basalt $/ 15 \%$ bentonite vs the $75 \%$ basalt $/ 25 \%$ bentonite mix. [NOTE: For comparisons between the Proctor compaction and the Hydraulic Static compaction the reader is referred to Figure 3, Page 17, Compaction Induced Basalt Particle Breakage after Proctor (Tamping.)] 


\subsection{STRENGTH OF COMPACTED PACKING MATERIALS MIXTURES}

\subsubsection{Sample Drying Techniques}

Sample drying techniques were developed to establish a relationship of unconfined compressive strength of the compaction samples with respect to their water content. Qualifying tests to establish the unconfined compressive strength test matrix (see the typical test matrix of Table 11) were performed on both wet and dried samples. The qualification test information clearly indicated that drying would affect the ultimate strength of samples, i.e., the drier samples were observed to exhibit higher ultimate strength at failure. Both "controlled" oven drying and "uncontrolled" atmospheric drying times were chosen for the test matrix. Drying times of 24, 48, and 72 hours were chosen for the test matrix and for comparative purposes, the same times were used for evaluation of the Proctor and hydraulic static compaction methods. An outside drying station was built. The "outside" drying station was a simple wood support structure with a top to protect the samples from the direct sunlight, i.e., to provide shade. The "inside" drying station consisted of standard metal storage cabinets ( $\sim 7$ ' $x$ $\left.4^{\prime} \times 1.5^{\prime}\right)$ located within the laboratory. Drying times of 24,48 , and 72 hours were arbitrarily chosen. These values were thought to be long enough to dry the samples outside/inside and oven drying for the sample size. In addition, an extremely long time would extend the testing period beyond the allotted time to complete the tests, i.e., FY constraints. Unfortunately, even with the availability of extremely hot weather, the 24,48 , and 72 hour times outside did not produce significant drying to increase the compressive strength of the samples. The oven drying did provide ample time for comparative results. It also supported the research effort by providing good "control" samples. The drying was performed in a thermostatically controlled oven at a temperature of $110^{\circ} \mathrm{C}={ }^{\circ} 5$ in accordance with ASTM Standards (ASTM 1987d).

Because of time constraints, the use of the outside and inside station drying was abandoned as a useful approach for the purpose of this report. The atmospheric drying could be a strong candidate for the full-scale packing 
fabrication if drying time is not a constraint to production. Or a combination of oven drying/atmospheric drying could be employed.

Table 10 is a summary of the effectiveness of both the atmospheric and

oven drying. The results are intended to show typical numbers for the drying techniques. As shown in the Table 10, the inside/outside drying was not effective; samples remained in an essentially as-compacted wet condition. Figure 10 shows a composite result of the two drying methods, oven and air.

\subsubsection{Unconfined Compressive Strength}

Unconfined compressive strength tests were carried out to compare the compaction methods for strength properties in a compression load environment. Samples were subjected to compressive loads in the wet condition, i.e., right after compaction and in various stages of drying. The tests were modeled after the ASTM Standards unconfined compressive strength tests (ASTM 1987d) and with the exception of the size of the test sample, i.e., length vs diameter ratio, the materials used and method of analyses correlated with the referenced standard (ASTM 1987d). The principle validity and importance of these unconfined compression tests is the comparison (ASTM 1987d) of the compaction method and post-compaction drying techniques, i.e., Proctor tamping vs hydraulic static compaction for similar Talbot mix designs with specific drying boundaries of time and drying location.

The following sections discuss the unconfined compressive strength tests for most the $75 \%$ basalt $/ 25 \%$ bentonite and $85 \%$ basalt/15\% bentonite mixtures. (Because of the limited experimental time available, the less promising $65 \%$ basalt $/ 35 \%$ bentonite was not included in the unconfined compressive strength test for FY 87.) Drying times were also an element in the analysis. Oven drying significantly affects the unconfined compressive strength. This is especially true of those samples hydraulically compacted.

\subsubsection{Proctor Compaction (Tamping) Methods}

Proctor samples were prepared using the methods developed for the dry density analysis (ASTM 1986c). However, for these tests the water content was chosen to optimize the results. Table 11 was developed for the first series of Proctor tests. The matrix was developed from a limited number of 
TABLE 10. Sample Orying Results

Proctor (Tamping)

$85 \%$ ba $15 \%$ be

Type of Drying Oven Dry, Hours Inside Hours Outside Hours

\begin{tabular}{|c|c|c|c|c|c|c|c|c|c|}
\hline & 24 & 48 & 72 & 24 & 48 & 72 & 24 & 48 & 72 \\
\hline $\begin{array}{l}\text { Moisture in } \% \\
\text { Before Drying }\end{array}$ & 10.8 & 10.8 & 10.8 & 10.8 & 10.8 & 10.8 & 10.8 & 10.8 & 10.8 \\
\hline $\begin{array}{l}\text { Moisture in } \% \\
\text { After Drying }\end{array}$ & $\begin{array}{l}1.36^{\star} \\
0.8639\end{array}$ & $\begin{array}{l}0.1696^{\star} \\
0.0169\end{array}$ & $\begin{array}{l}0.0302^{\star} \\
0.1099\end{array}$ & 9.76 & & & 9.85 & & \\
\hline
\end{tabular}

$85 \%$ ba $/ 15 \%$ be (d 29,000 lbs (2309 psi)

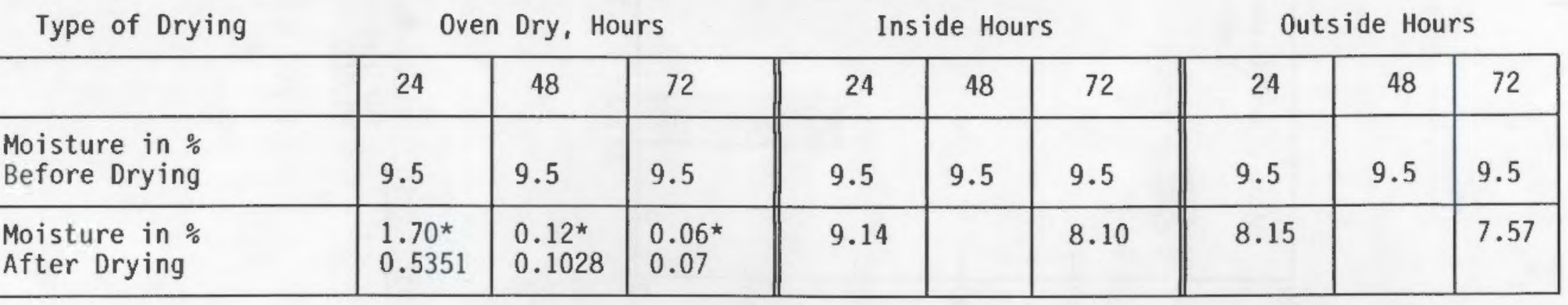

* High and Low Rates

** All results are for individual samples; each sample dried for 24,48 or 72 hours, loaded to failure and analyzed for water content. 


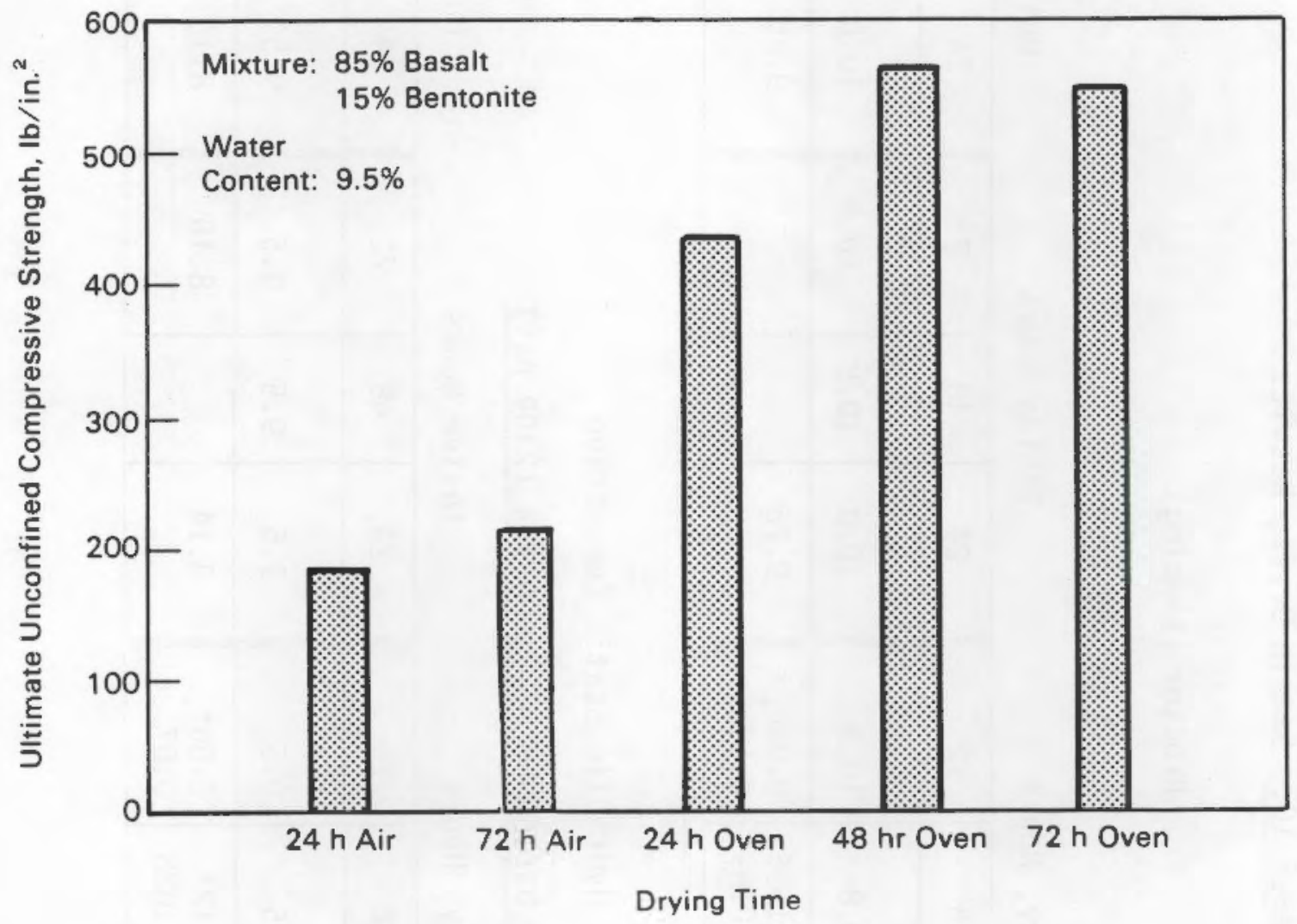

FIGURE 10. Ultimate Compressive Strength vs Drying Time for Hydraulic Static Compaction Samples at 29,000 lbs (2309 psi) Load

1 psi $=6.89 \mathrm{kPa}$ 
qualifying unconfined compressive tests on both wet and dry samples. The load rate shown in Table 11 was used throughout all of the unconfined compression tests. The estimated time, 5 to 7 minutes, proved to be, generally, too short for the dried samples; testing times of 10 to 12 minutes were recorded for the oven dried samples.

Results of the unconfined compressive strength are shown in Appendix $D$. During testing the advantages of oven drying became increasingly conspicuous as compared to the inside/outside method. The inside/outside atmospheric drying was simply not effective on the short time interval chosen. The results of the 24-hour inside and outside tests (Appendix D), 206-P85-8 \& 12, top of left column, Page 1, indicate that little drying was accomplished and that little difference exists between the drying locations. These samples failed at approximately $765 \mathrm{kPa}$ (111 psi) of load.

Oven drying for the prescribed 24- and 48-hour time periods resulted in greatly improved unconfined compressive strengths. The difference in ult imate strength between 48 and 72 was not significant. (This was also true for the hydraulic static compaction method.) Figure 11 shows the correlation between the drying times. The figure indicates that for this size of sample, a 48-hour drying period is ample time; very little ultimate strength improvement is shown for the 72-hour vs the 48-hour drying times. However, the 72-hour dried samples do exhibit less strain and more strength at the intermediate loads. 


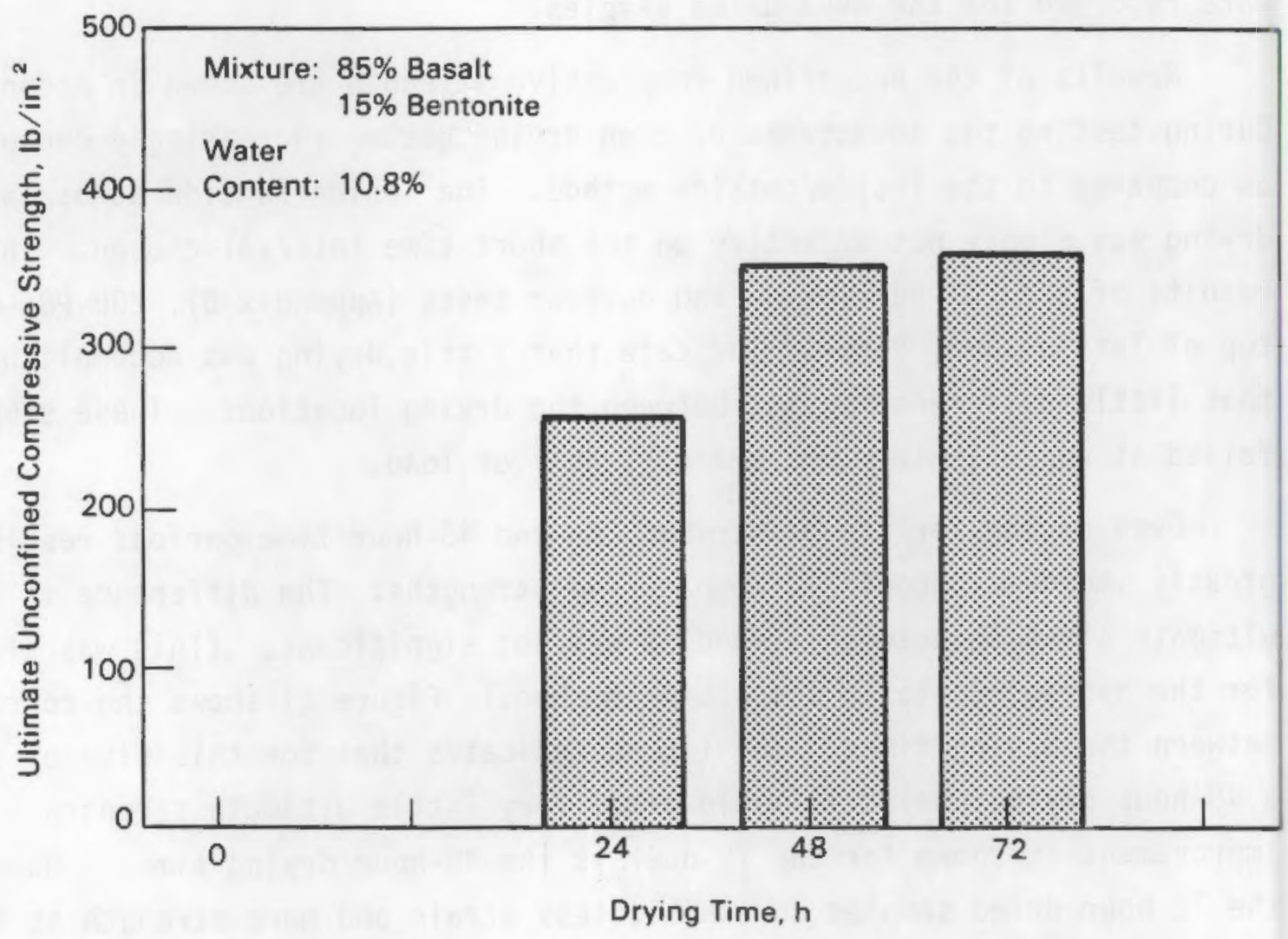

FIGURE 11. Ultimate Compressive Strength ys Drying Time for Proctor Tamping Compaction Samples

$1 \mathrm{psi}=6.89 \mathrm{kPa}$ 
TABLE 11. Test Matrix for $85 \%$ ba $/ 15 \%$ be Mixtures Proctor Method

$\begin{array}{ll}\text { Water } & 10.8 \% \\ \text { Load Rate } & 400 \mathrm{lb} \text { in } 15 \text { seconds } \\ \text { Load-constant } & 45 \text { seconds } \\ \text { Total Expected Time } & 5 \text { to } 7 \text { minutes }\end{array}$

DRYING TECHNIQUES FOR THE 13 SAMPLES

\begin{tabular}{|c|c|c|}
\hline & Sample & Hours \\
\hline \multirow[t]{3}{*}{ Oven dry } & 3 & 24 \\
\hline & 3 & 48 \\
\hline & 3 & 72 \\
\hline \multicolumn{3}{|l|}{ Air dry } \\
\hline \multirow[t]{2}{*}{ Outside MDL } & 1 & 24 \\
\hline & 1 & 72 \\
\hline \multirow[t]{2}{*}{ Inside MDL } & 1 & 24 \\
\hline & 1 & 72 \\
\hline Total tests: & 13 & \\
\hline
\end{tabular}

For the Proctor compaction method, the upper limit for unconfined compressive strength occurred in testing with sample test 206-P-85-5, 48-hour oven dry at $2526 \mathrm{kPa}(366.28 \mathrm{psi})$. Sample 206-P-85-10, 72-hour oven dry, was essentially the same at unconfined compressive strength of $2496 \mathrm{kPa}(362.33$ psi). Sample \#5 displayed a smaller axial strain $0.0672 \mathrm{~mm} / \mathrm{mm}$ (in./in.) vs $0.0746 \mathrm{~mm} / \mathrm{mm}$ (in./in.) hence the larger strength even though the sample failed with a smaller load. Again, for the total drying times used, the ultimate sample strength for both samples is essentially the same. The additional drying time for sample $\# 10$ had little effect on the ultimate strength results.

Stress/strain curves were developed for the unconfined compressive strength tests. For the Proctor compaction method, these are shown in Figures 12, 13, and 14. The strain is plotted as the abscissa and the strength as the ordinate. Figure 12 shows excellent repeatability between 
test 206-P-85-2 and 4; this is also the case for Figure 13, test 206SC8529-5 and 7, the 48-hour dried sample. The curves of Figure 14 (the 72-hour dried sample) show the most compatible curves of any of the Proctor samples; all three tests indicate the same general shape and slope. Although, inconclusive at this time, the consistency of the 72-hour dry curves coupled with the higher intermediate strength values may be a reason for a longer drying period of compacted samples, i.e., additional curing time may enhance the overall strength of the material.

Ory densities of the test samples were obtained for each sample after testing to failure. All the densities regardless of the mixture design were very consistent with the previous results reported, i.e., for the $85 \%$ basalt/15\% bentonite with $10.8 \%$ water, densities of $2.07 \mathrm{~g} / \mathrm{cm}^{3}\left(129 \mathrm{lb} / \mathrm{ft}^{3}\right)$ may be routinely achieved with the Proctor compaction method.

\subsubsection{Static Hydraulic Compaction Methods}

Unconfined compressive strength tests were carried out on several different mixtures of basalt and bentonite that were compacted using the Hydraulic Static Compaction method. The results of these tests are shown in Appendix $D$. The tests as noted in the introductory section, 5.2.2, were principally performed for comparative purposes, i.e., static compaction vs Proctor compaction. The sections shown below (a., b., and c.) discuss the results of these compaction tests.

\section{a. $85 \%$ Basalt $/ 15 \%$ Bentonite Compacted at $15,920 \mathrm{kPa}$ (2309 psi)}

Unconfined compressive strength tests were performed on samples compacted for the $85 \%$ basalt $/ 15 \%$ bentonite mixture with the optimum water content of $9.5 \%$ (Figure 6 ). The results of these tests are shown in Appendix D, Tests 2065C8529-4 through 16 . The results shown for the 48-hour and 72-hour oven dried samples indicate failure strengths as high as $4398 \mathrm{kPa}$ (638 psi) for the 72 -hour oven dry and $4008 \mathrm{kPa}$ (581 psi) for the 48 -hour dry. In general, the 72-hour dried samples out-performed the 48-hour samples. The 24-hour oven dried samples also exhibited good strength with failure values between $2942 \mathrm{kPa}(427 \mathrm{psi})$ and $3073 \mathrm{kPa}$ (446 psi). The 


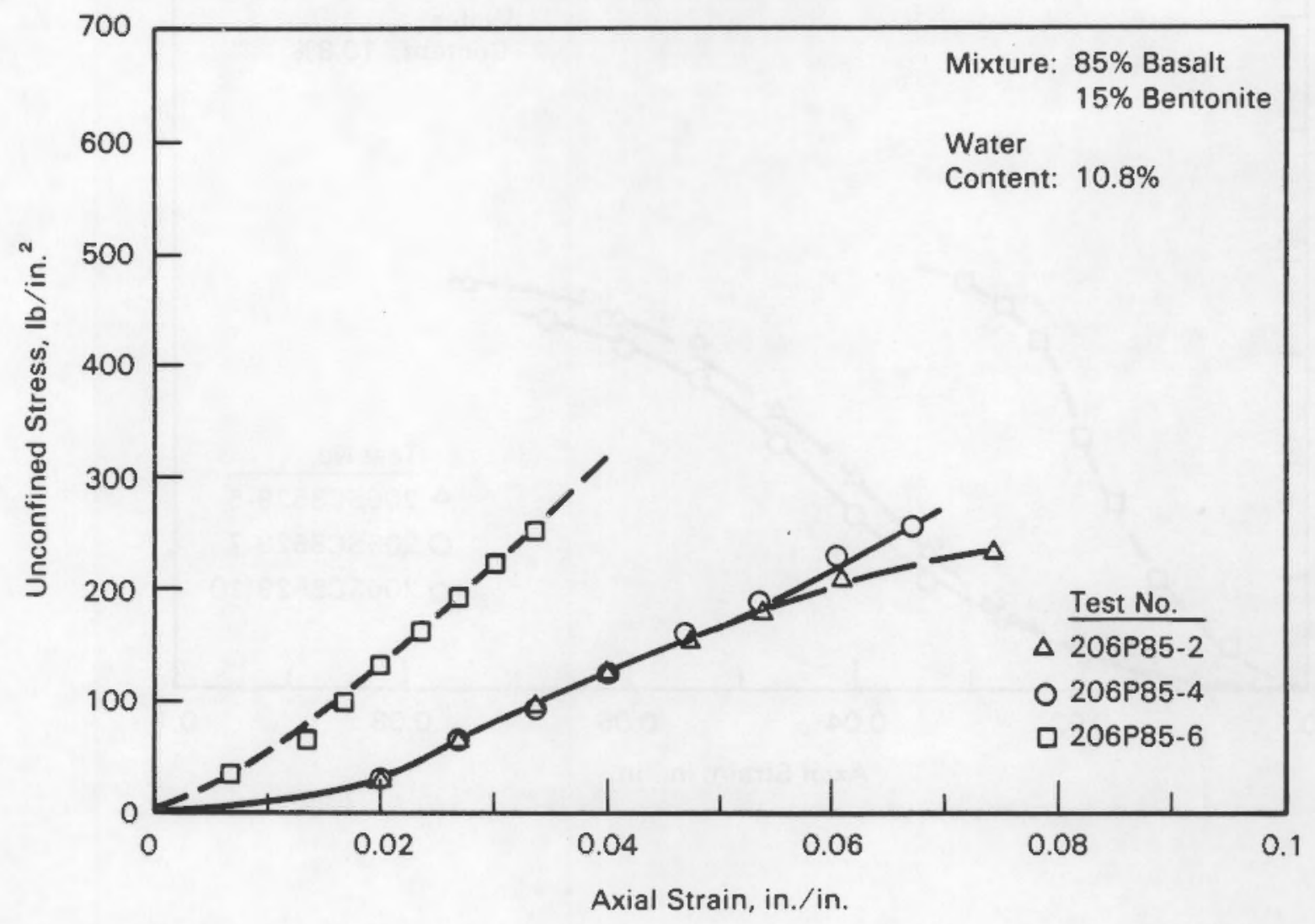

FIGURE 12. Stress/Strain Curve (24 hr) Oven Dried Samples, Proctor Tamping Method

SI Conversion: $1 \mathrm{psi}=6.89 \mathrm{kPa}$ 


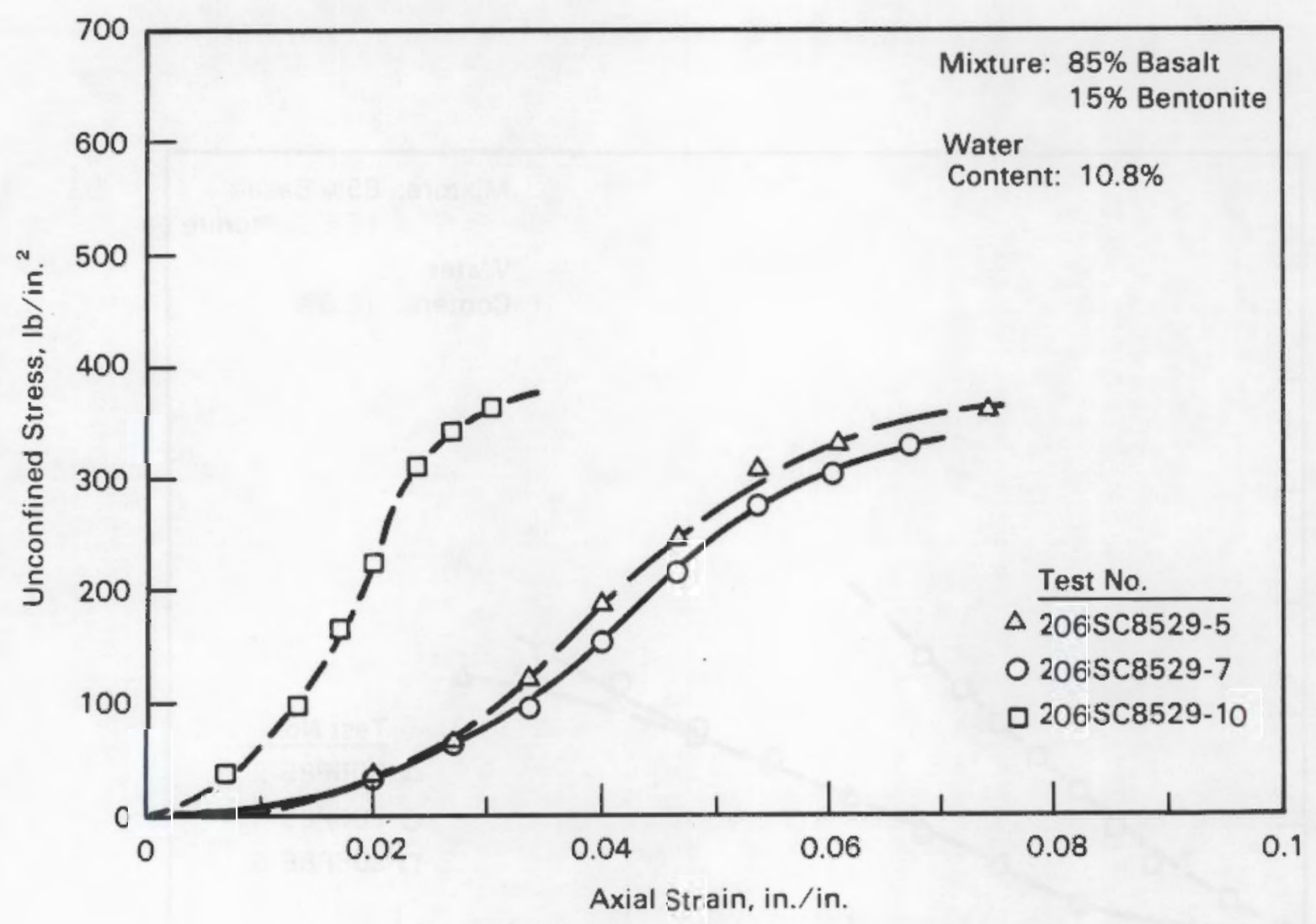

FIGURE 13: Stress/Strain Curve ( $48 \mathrm{hr}$ ) Oven Dried Samples, Proctor Tamping Method

SI Conversion: $1 \mathrm{psi}=6.89 \mathrm{kPa}$ 


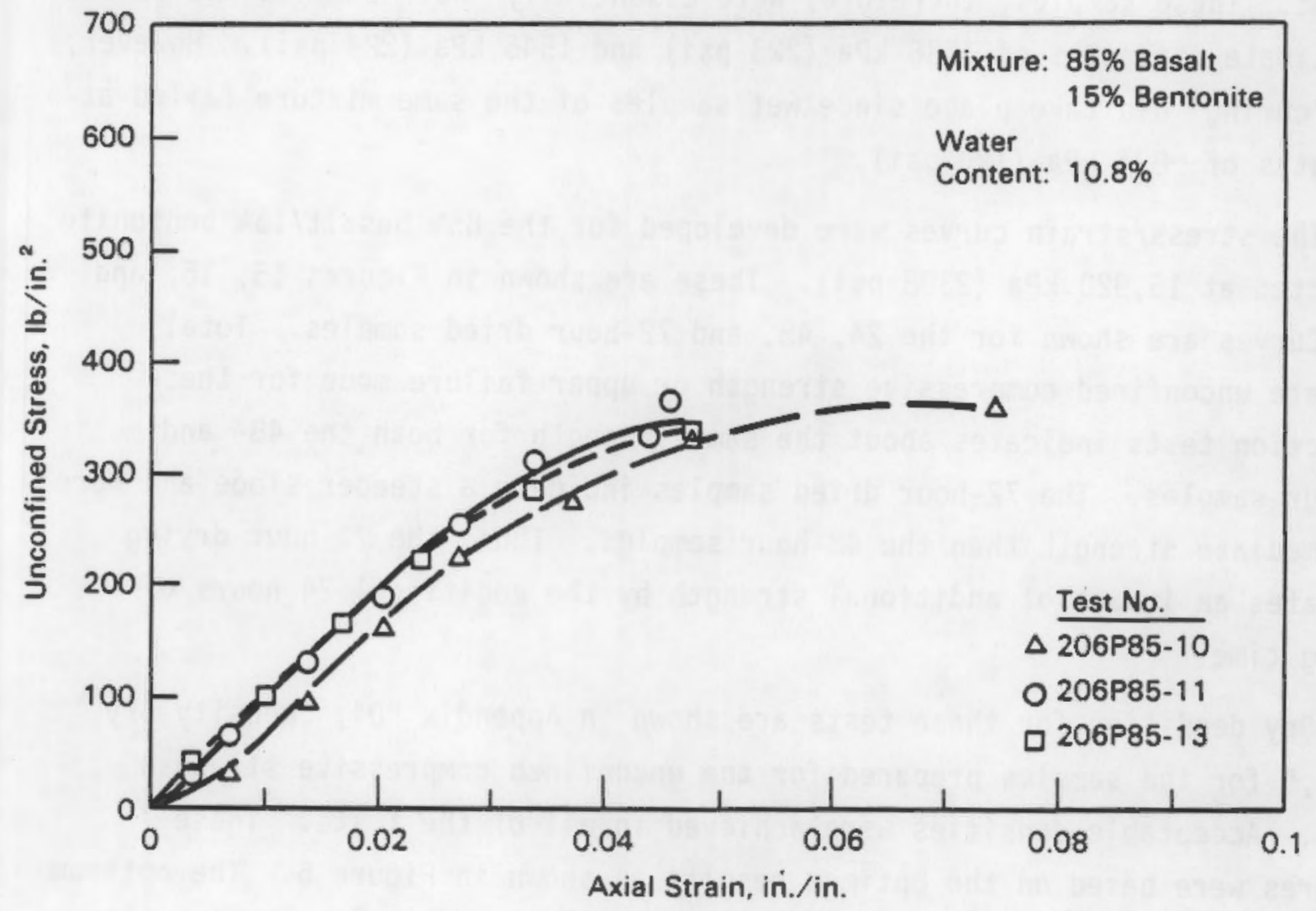

FIGURE 14: Stress/Strain Curve ( $72 \mathrm{hr}$ ) Oven Dried Samples, Proctor (Tamping) Method

SI Conversion: 1 psi $=6.89 \mathrm{kPa}$ 
24-hour inside and outside dried samples performed poorly in comparison to the oven dried samples. This was also true for the 72-hour inside dried sample. Water content for the atmospheric dried samples, even after the 72 hours remained high, i.e., samples 206SC8529-11 and 12 at 8.1 and $7.6 \%$ water content. These samples, therefore, were essentially "wet" samples and failed at ultimate strengths of $1536 \mathrm{kPa}(223 \mathrm{psi})$ and $1545 \mathrm{kPa}$ (224 psi). However, some "curing" did take place since wet samples of the same mixture failed at strengths of $\sim 824 \mathrm{kPa}$ (120 psi).

The stress/strain curves were developed for the $85 \%$ basalt $/ 15 \%$ bentonite compacted at $15,920 \mathrm{kPa}(2308 \mathrm{psi})$. These are shown in Figures 15, 16, and 17. Curves are shown for the 24, 48, and 72-hour dried samples. Total ultimate unconfined compressive strength or upper failure mode for these compaction tests indicates about the same strength for both the 48- and 72-hour samples. The 72-hour dried samples indicate a steeper slope and more intermediate strength than the 48-hour samples. Thus, the 72 hour drying indicates an impact of additional strength by the additional 24 hours of curing time.

Dry densities for these tests are shown in Appendix "O", "Density Dry $\mathrm{g} / \mathrm{cm}^{3}$, " for the samples prepared for the unconfined compressive strength tests. Acceptable densities were achieved in all of the tests. These mixtures were based on the optimum results as shown in Figure 6 . The optimum density from the curve was plotted at $2.20 \mathrm{~g} / \mathrm{cm}^{3}\left(137 \mathrm{lb} / \mathrm{ft}^{3}\right)$. The results as shown in Appendix D, tests 206SC8529-4 through 16, indicated that the optimum numbers were achieved in five of the 13 tests; futhermore, the majority of the densities was very close to optimum, i.e., except for one at $2.16 \mathrm{~g} / \mathrm{cm}^{3}\left(135 \mathrm{lb} / \mathrm{ft}^{3}\right)$, all the others were $\geq 2.18 \mathrm{~g} / \mathrm{cm}^{3}$ (136 psi).

b. $75 \%$ Basalt $/ 15 \%$ Bentonite Compacted at $15,920 \mathrm{kPa}$ (2309 psi)

Compressive strength tests for the $75 \%$ basalt/ $25 \%$ bentonite mixtures at the optimum water, Figure 4, were carried out to establish the relationship between the $15 \%$ bentonite vs the $25 \%$ bentonite mixtures. However, these test were not as extensive principally because the air drying was abandoned as a 


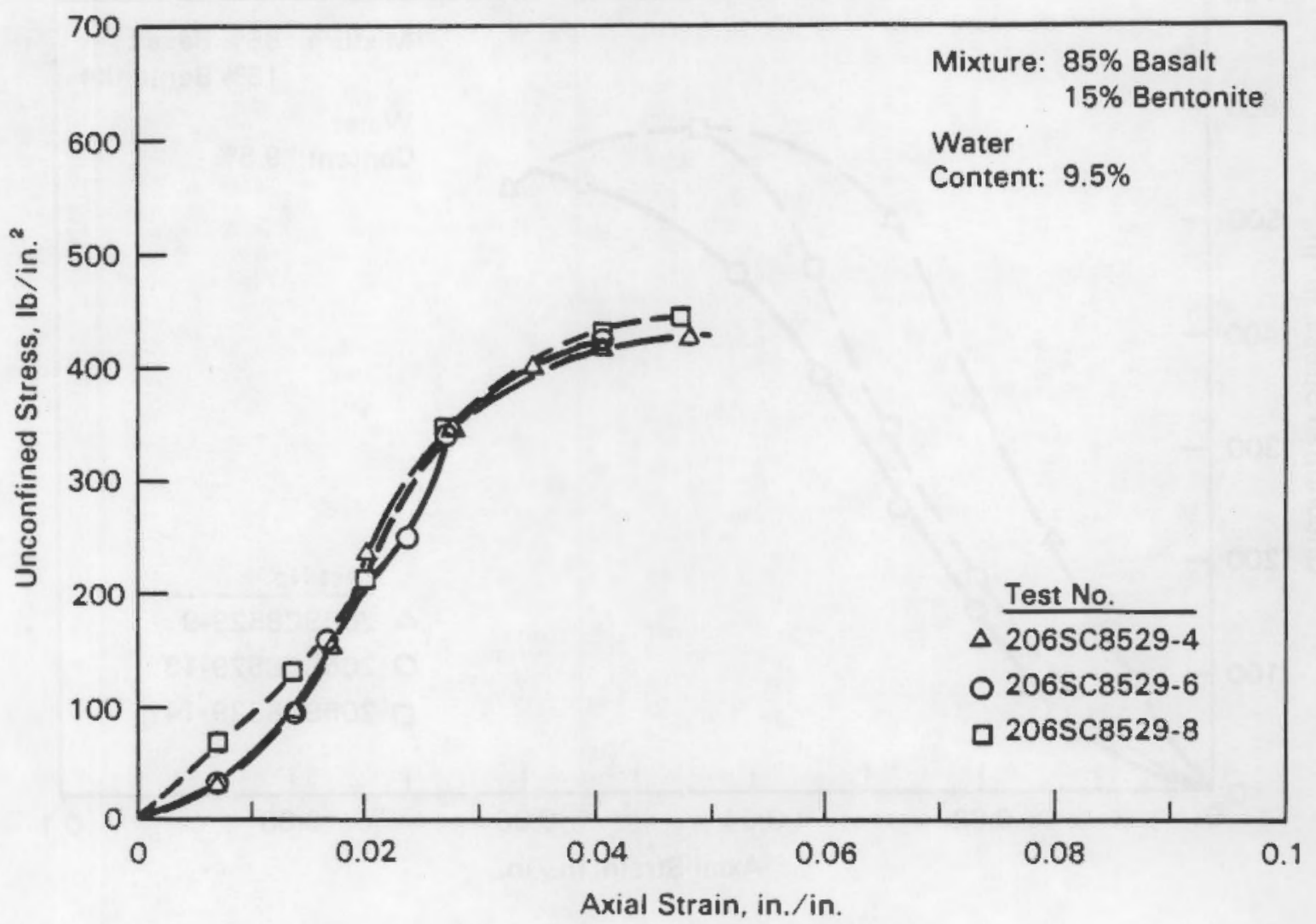

FIGURE 15. Stress/Strain Curve $(24 \mathrm{hr}$ ) Oven Dried Samples, Hydraulic Static Compaction at 29,000 1bs

(2309 psi) Load

SI Conversion: $1 \mathrm{psi}=6.89 \mathrm{kPa}$ 


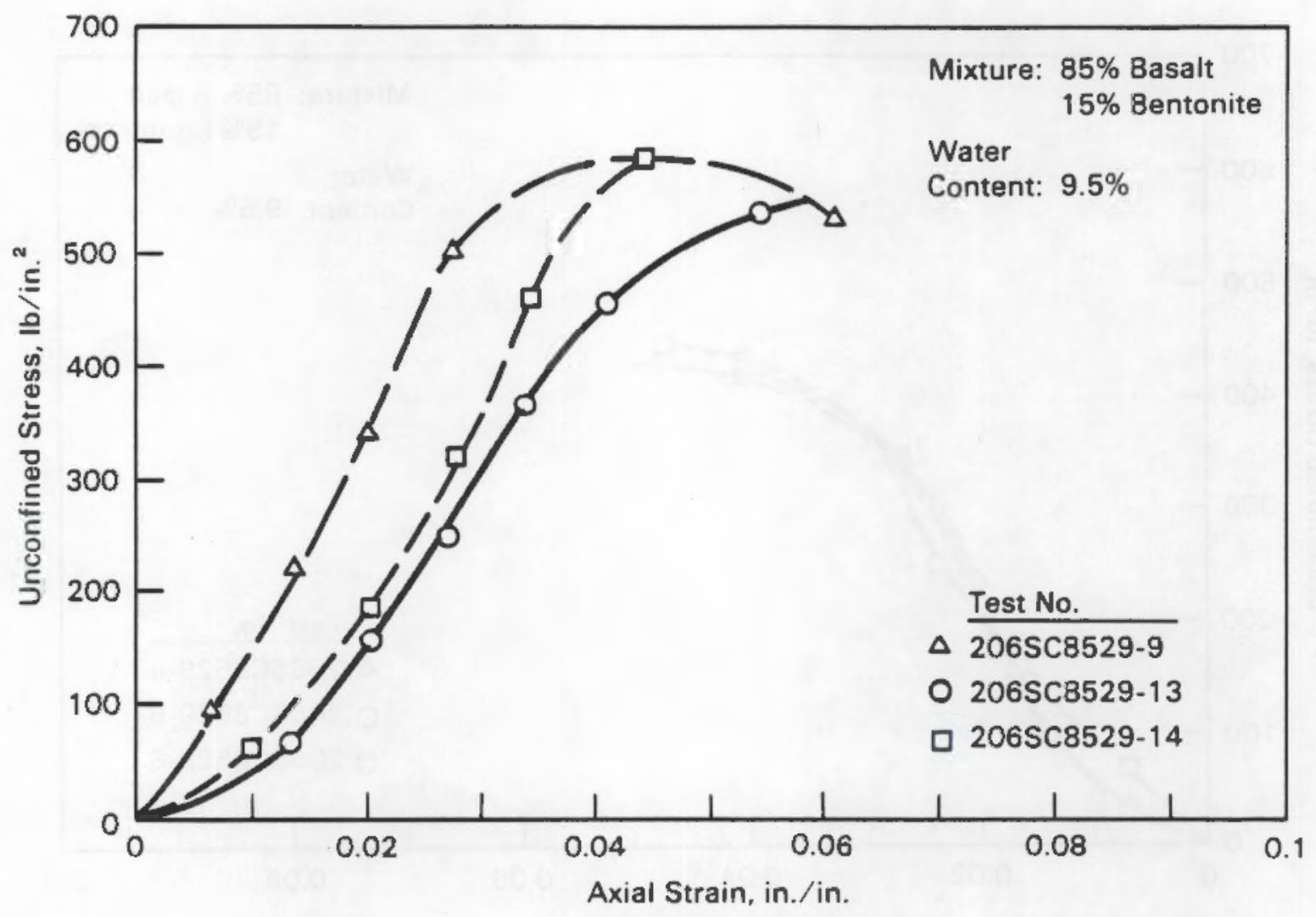

FIGURE 16. Stress/Strain Curve (48 hr) Oven Dried Samples, Hydraulic Static Compaction at 29,000 lbs (2309 psi) Load

SI Conversion: $1 \mathrm{psi}=6.89 \mathrm{kPa}$ 


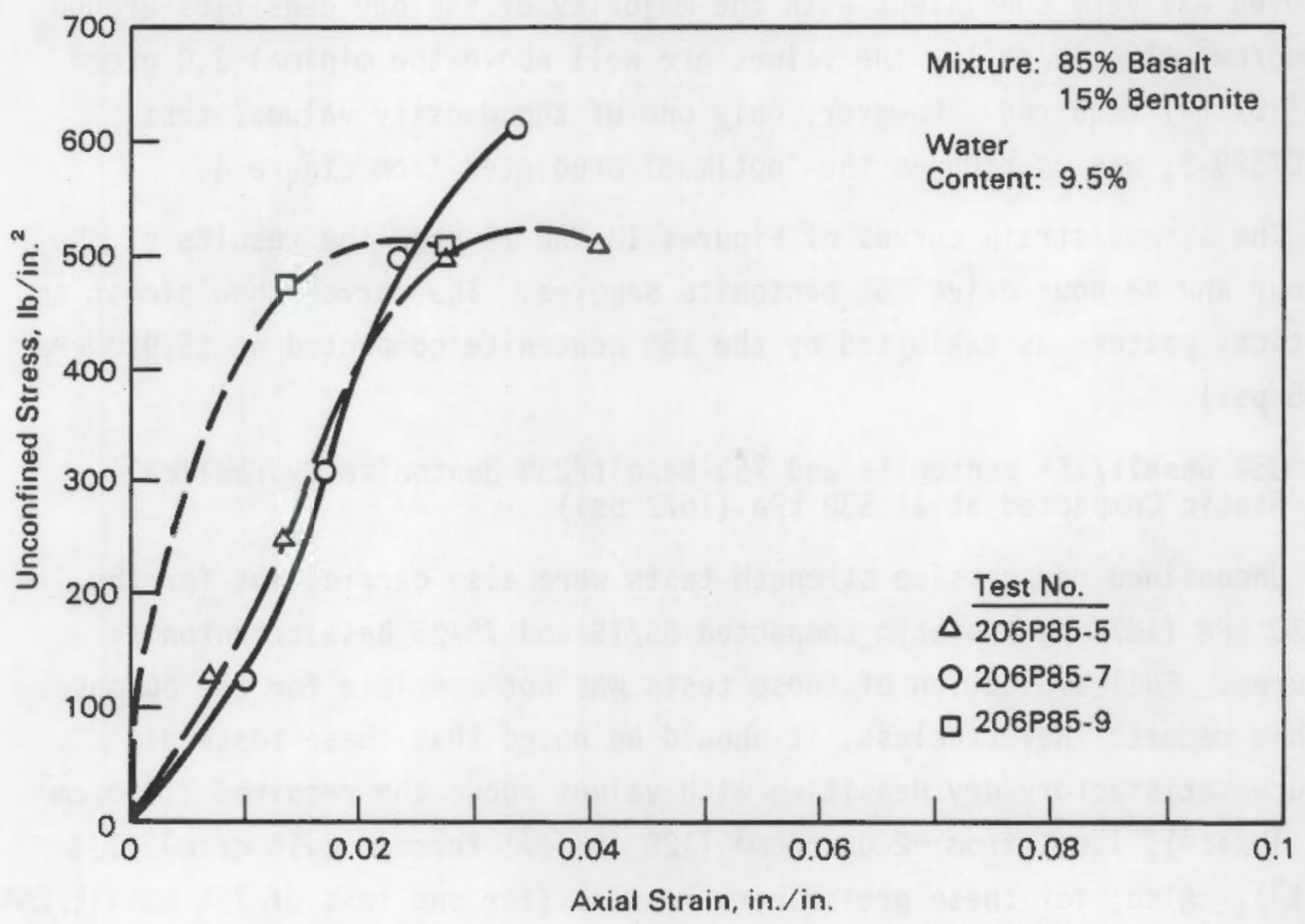

FIGURE 17. Stress/Strain Curve (72 hr) Oven Dried Samples, Hydraulic Static Compaction at 29,000 lbs (2309 psi) Load

SI Conversion: $1 \mathrm{psi}=6.89 \mathrm{kPa}$ 
test variable. In addition, the 72-hour long oven drying time was not used. The data obtained is shown in Appendix D, tests 206SC7529-1 through 6. The highest ultimate unconfined compressive strength values were $3640 \mathrm{kPa}$ (527 psi) and $3835 \mathrm{kPa}(556 \mathrm{psi})$ for the 48 -hour dried samples. These values compare favorably with the $85 \%$ basalt/ $15 \%$ bentonite mixtures. The density achieved was very consistent with the majority of the dry densities around $2.14 \mathrm{~g} / \mathrm{cm}^{3}\left(134 \mathrm{lb} / \mathrm{ft}^{3}\right)$. The values are well above the minimal $2.0 \mathrm{~g} / \mathrm{cm}^{3}$ $\left(125 \mathrm{lb} / \mathrm{ft}^{3}\right.$ ) required. However, only one of the density values, test 2065C7529-3, was as high as the "optimum" predicted from Figure 4.

The stress/strain curves of Figures 18 and 19 show the results of the 24-hour and 48 -hour dried $25 \%$ bentonite samples. The curves show almost an identical pattern as exhibited by the $15 \%$ bentonite compacted at $15,920 \mathrm{kPa}$ (2308 psi).

c. $85 \%$ Basalt $/ 15 \%$ Bentonite and $75 \%$ Basalt $/ 25 \%$ Bentonite Hydraulically Static Compacted at $11,530 \mathrm{kPa}$ (1672 psi)

Unconfined compressive strength tests were also carried out for the $11,530 \mathrm{kPa}$ (1672 psi) static compacted $85 / 15$ and $75 / 25$ basalt/bentonite mixtures. Full evaluation of these tests was not complete for the purposes of this report. Nevertheless, it should be noted that these tests did produce satisfactory dry densities with values above the required $2.0 \mathrm{~g} / \mathrm{cm}^{3}$ $\left(125 \mathrm{lb} / \mathrm{ft}^{3}\right)$, i.e., from $\sim 2.05 \mathrm{~g} / \mathrm{cm}^{3}\left(128 \mathrm{lb} / \mathrm{ft}^{3}\right)$ through $2.14 \mathrm{~g} / \mathrm{cm}^{3}(134$ $\mathrm{lb} / \mathrm{ft}^{3}$ ). Also, for these preliminary results (for one test of $75 \%$ basalt $/ 25 \%$ bentonite compacted at $11,530 \mathrm{kPa}--1672$ psi) a very acceptable and comparable compressive strength of $4190 \mathrm{kPa}$ (607 psi) was achieved for a 48 -hour dried sample. Further tests will be necessary to determine the real worth of the lower static force. Compaction in the $10,980 \mathrm{kPa}$ (1590 psi) range could be an important cost factor, i.e., energy cost associated with the $16,470 \mathrm{kPa}$ (2388 psi) compaction vs the energy cost of the $10,980 \mathrm{kPa}$ (1590 psi) range.

\subsubsection{Comparisons of Unconfined Compressive Strength of Proctor vs Hydraulic Static Compaction Methods}

Unconfined Compressive Strength analys is of the compaction methods explicitly shows that the Hydraulic Static Compaction is the superior method for achieving higher strength values when compared to similar samples 


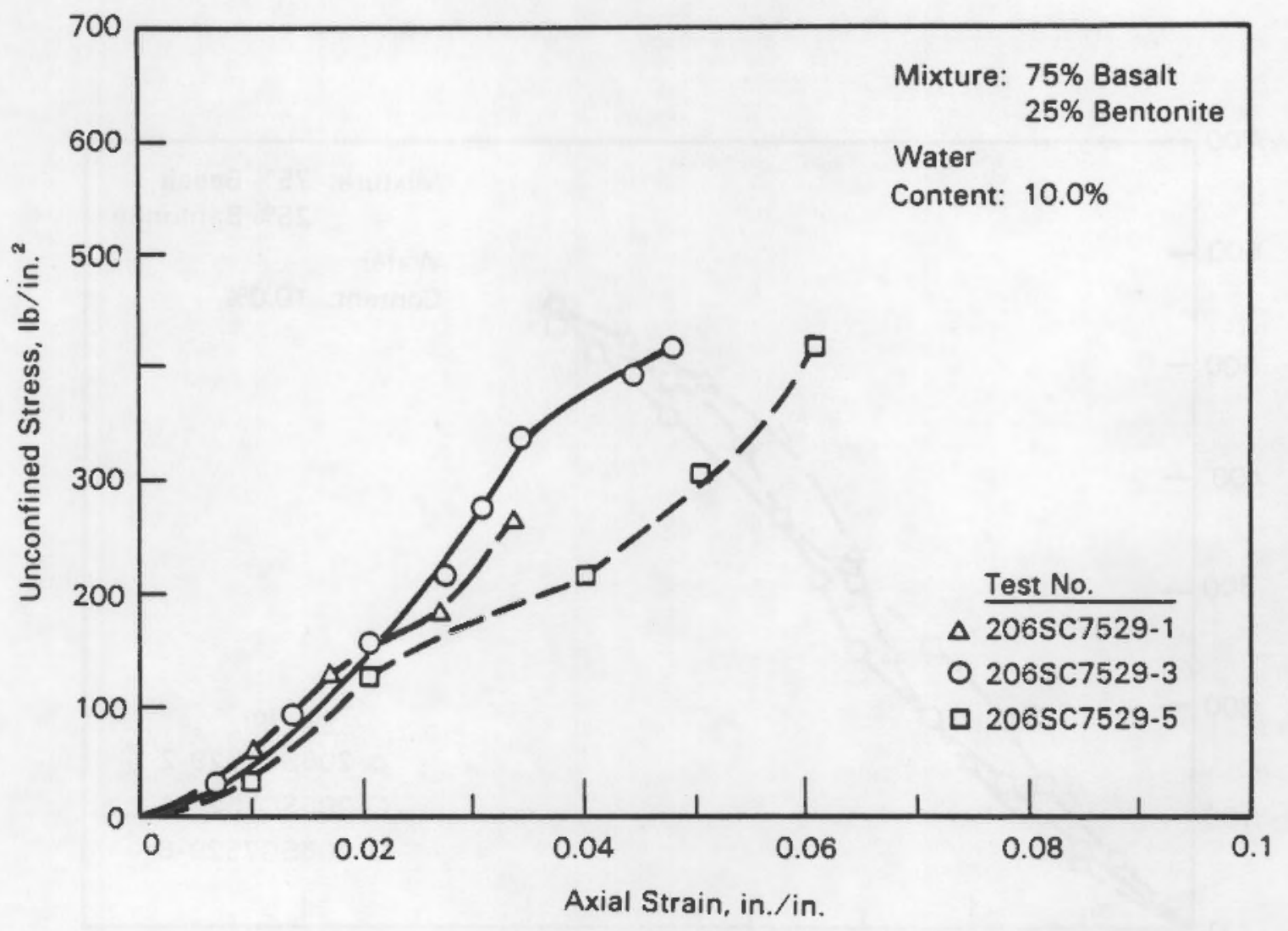

FIGURE 18. Stress/Strain Curve (24 hr) Oven Dried Samples, Hydraulic Static Compaction at 29,000 1bs (2309 psi) Load

SI Conversion: 1 psi $=6.89 \mathrm{kPa}$ 


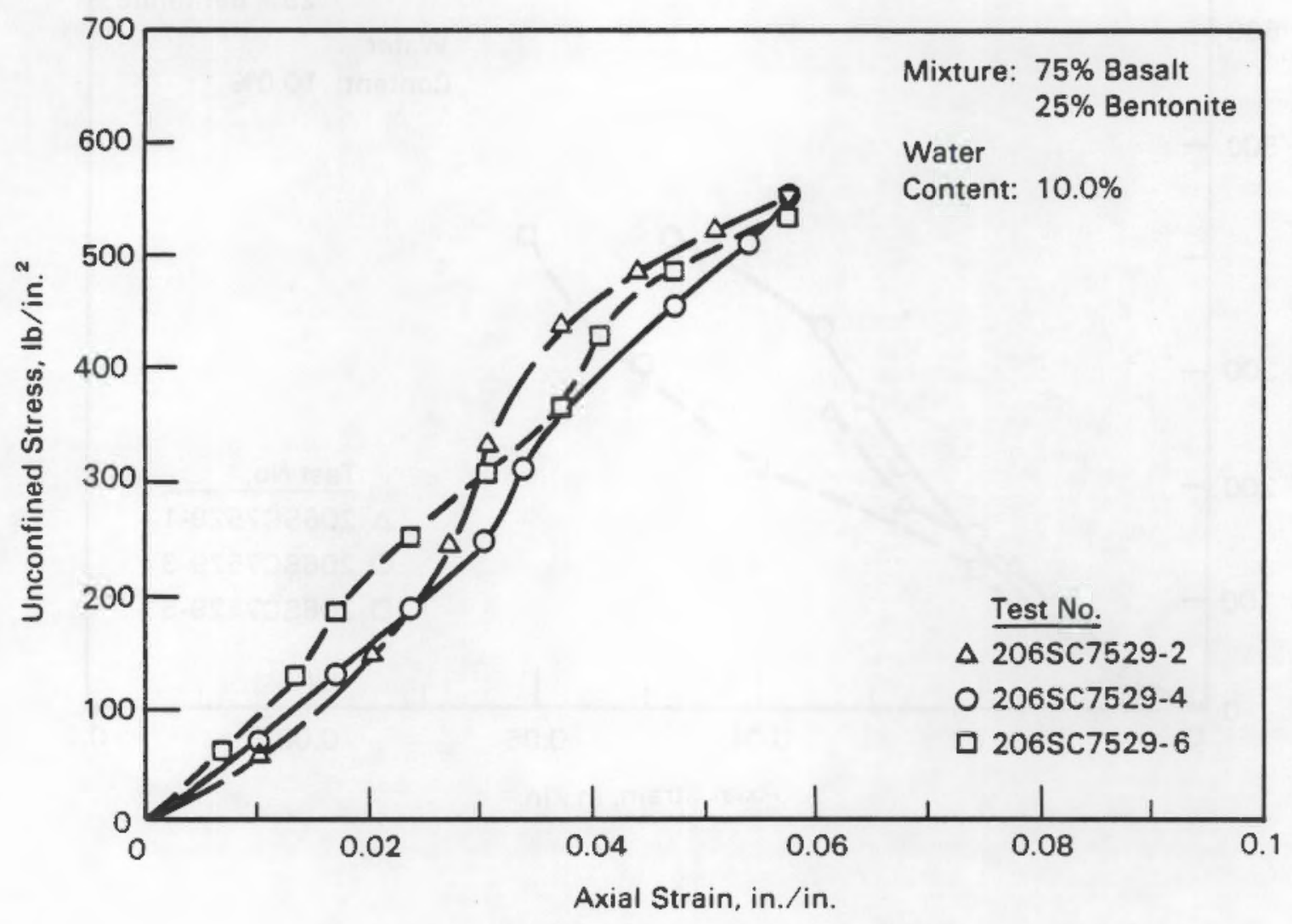

FIGURE 19. Stress/Strain Curve (48 hr) Oven Dried Samples, Hydraulic Static Compaction at 29,000 lbs

(2309 psi) Load

SI Conversion: 1 psi $=6.89 \mathrm{kPa}$ 
compacted by using the Proctor method. A comparative relationship was also investigated for similar mixtures compacted and tested at 15,920 kPa (2309 psi) vs $11,530 \mathrm{kPa}$ (1672 psi). The tests were performed insofar as possible to the ASTM Standards (ASTM 1987d); however, the samples, were compacted in a nominal standard Proctor 4-inch diameter mold that did not provide the "classic," acceptable, 2 to 2.5 height-to-diameter ratio (ASTM 1987d). Because of the nonconformance to the height to diameter ratio, the results were not interpreted for acceptable values, i.e., is $3450 \mathrm{kPa}$ (500 psi) unconfined compressive strength satisfactory or is a value of $3450 \mathrm{kPa}$ (500 psi) reasonable? The results for the purposes of this report are to consider the comparative values of the two methods. Table 12 gives a comparative tabulation of the strength values. The table indicates the high range values of unconfined compressive strength of similar compacted mixtures.

In all cases, the Hydraulic Static Compaction method produced higher unconfined compressive strength values vs the Proctor method by a factor of approximately 1.6 times. The highest results are shown for the $85 \%$ basalt/ $15 \%$ bentonite mix. The amount of compaction load is still in question, however, the data would indicate that acceptable strength may be achieved at values less than the $15,920 \mathrm{kPa}$ (2309 psi) compaction pressure. 
TABLE 12. Comparison of Unconfined Compressive Strength of Compacted Packing Mixtures

\begin{tabular}{llr}
\multicolumn{1}{c}{ Mixture } & \multicolumn{1}{c}{ Compaction Method } & Compressive Strength \\
$85 \% \mathrm{ba} / 15 \%$ be & Proctor & 360 to $366 \mathrm{psi}$ \\
$85 \% \mathrm{ba} / 15 \%$ be & Hydraulic Static (2309 psi) & 607 to $612 \mathrm{psi}$ \\
$75 \% \mathrm{ba} / 25 \%$ be & Hydraulic Static (2309 psi) & 539 to $556 \mathrm{ps} i$ \\
$75 \% \mathrm{ba} / 25 \% \mathrm{be}$ & Hydraulic Static (1672 psi) & 486 to $607 \mathrm{psi}$ \\
& &
\end{tabular}

\subsubsection{Tensile Strength}

An investigation was initiated to determine the tensile strength of the basalt/bentonite packing material. The tensile strength data is necessary, in combination with other mechanical properties such as compressive and shear strength, to not only verify the feasibility of handling prefabricated packing rings, but to actually develop packing handling methods for the full range of packing element manipulation from fabrication to emplacement. The packing material must have sufficient mechanical strength for handling if it is to be used in the presently conceived waste package system. Therefore, an effort has been undertaken-in concert with the other packing development tasks to determine the tensile strength of the packing material.

\subsubsection{Procedure Development}

A preliminary investigation was conducted to determine an appropriate method(s) to conduct tensile strength testing of the proposed basalt/ bentonite packing material. Given the material's apparent dissimilar physical properties to other materials for which there are standard ASTM tensile testing procedures, a search was made for a procedure which would be applicable to the packing material. Both an indirect method and a direct method were identified. 
The first general method investigated used splitting tensile strength techniques found in both ASTM D-3967-81, "Splitting Tensile Strength of Intact Rock Core Specimens," (ASTM 1987b) and ASTM C-496-86, "Splitting Tensile Strength of Cylindrical Concrete Specimens." (ASTM 1987a.) This method is classified as indirect, meaning that a method other than a uniaxial tensile testing is used to test the specimen and the tensile strength is derived from the results. In this case, a cylindrical specimen with sufficiently high compressive and shear strength (like a hard rock core or cured concrete) is loaded compressively between two plates, each approximately parallel to the axis of the cylinder and to each other. When the applied load is high enough, the specimen will split apart approximately along a rectangular plane through the center of the specimen along its full length parallel to its axis and perpendicular to the plates. Theory holds that the tensile strength at which the cylinder splits or pulls apart can be calculated as follows:

$$
\sigma_{t}=2 P / \pi L D
$$

where

$$
\begin{aligned}
\sigma_{t} & =\text { splitting tensile strength, psi (Pa) } \\
P & =\text { applied squeezing load, lbf }(N) \\
L & =\text { length of cylindrical specimen, in. (m) } \\
D & =\text { diameter of the cylinder, in. (m) }
\end{aligned}
$$

The advantages of this test are its simplicity and low cost application. In addition, application of this technique has importance due to its unique similarity to the postulated types of loading to which the packing elements may be exposed in the field. This is so, because the handling of packing rings will generate reasonably complicated stress fields, including various combinations of compressive and tensile stress fields. By obtaining tensile strengths in the presence of compressive stresses, the test results will be more representative of the actual field conditions. Also, for our tensile testing application, the results from the use of this method may be more comparable to the results obtained from the other packing development tests 
since compressive tests and similar sized cylindrical specimens are used for both types of tests.

A potential problem with using this procedure for determining the splitting tensile strength of the packing material is the permanent deformation evident at the point of load applications unlike the absence of permanent deformation evident with harder materials. Depending on the extent of surface deformation, it may no longer present line load contact and, therefore, reduce the accuracy of the derived tensile strength values.

Two trial tests were performed with this splitting tensile strength method to determine its feasibility and to aid in subsequent procedure development. The tests were run according to ASTM D-3967-81, "Splitting Tensile Strength of Intact Rock Core Specimens," except that compacted cylinders of basalt/bentonite mix were used instead of rock core. Enough $75 \%$ basalt/25\% bentonite material was mixed with a moisture content of $10 \%$ to form two 4-inch basalt/bentonite cylindrical specimens. A Talbot mix design was used with the gradations and percentages being the same as detailed in Chapter 4.D. Physical Properties, of this report. The cylindrical specimens were compacted at $\sim 15900 \mathrm{kPa}(2300 \mathrm{psi})$ in two lifts. Splitting tensile strength tests were performed on these specimens--one specimen in its moist compacted state and the other oven dried. The failure cracks of the two specimens appeared approximately vertical through the diametral plane of loading, with some deformation occurring at the top and bottom of the specimens where the load was applied through bearing strips of cardboard. Preliminary results showed a splitting tensile strength of about $276 \mathrm{kPa}$ and $152 \mathrm{kPa}$ (40 psi and $22 \mathrm{psi}$ ), respectively, for the moist and dried specimens. Although these strength values appeared to be reasonable, no conclusive deductions were made because of the limited number of tests (only two) for this mix design ( $75 \%$ basalt $/ 25 \%$ bentonite). In addition, questions arose about the permanent deformation which occurred along the paths of load application. This prompted a search for another testing method.

ASTM C-196, "Tensile Strength of Hydraulic Cement Mortars." (ASTM 1987c was also investigated.) This direct method is one where "dogbone-shaped" briquet specimens are formed from the material to be tested. The large 
opposing ends of the briquet are placed in special fixtures for loading the specimen in uniaxial tension until the ultimate strength is exceeded and the briquet breaks at its midpoint/smallest cross section. By knowing the breaking load and the cross-sectional area of the briquet at the break, the ultimate strength of the material can be calculated.

A total of eight briquets was hydraulically static compacted in the standard briquet mold. The mixture used was the Talbot $85 \%$ basalt/15\% bentonite specification mixed to yield an $8.5 \%$ moisture content. Five of the specimens were tested at the moist condition and the remaining three were first oven dried and then tested.

The methodology yielded mixed results. Three of the five moist briquets broke at the point of gripment by the fixtures, probably due to the resultant combined tensile and compressive stresses at that point. The dried briquets all failed at the narrow cross section as was intended, probably because the higher relative compressive strength of the dried material mitigated the stress concentration within the dried specimen at the point of fixture gripment. This allowed adequate breaking load to be transmitted to a narrower cross section at the specimen midpoint. The calculated ultimate strengths of the dried specimens ranged from $123 \mathrm{kPa}$ to $157 \mathrm{kPa}(17.8 \mathrm{psi}$ to $22.8 \mathrm{psi}$ ), and from $92 \mathrm{kPa}$ to $186 \mathrm{kPa}(13.4 \mathrm{psi}$ to $26.9 \mathrm{psi}$ ) for the moist specimens. These strengths were calculated by using the breaking load and the area from the narrowest cross section, even though the sample may not have broken at the point. The properly broken saturated specimens yieided results at the high end of the range.

Two areas of concern prevented the use of this method at this time for determining the tensile strength of the packing material. The first (and probably the most important) was the specimens breaking unpredictably at the point of fixture gripment and not at the narrowest cross section at the center of the briquet. This could probably be mitigated by designing fixtures which apply the tensile load over larger areas at the ends of the specimens to eliminate the concentrated pinch point. The other problem was that the standard briquet mold forms a specimen with approximately 1 in.2 area at the intended midpoint breaking section. The area projected by the 
sized aggregate used in the packing mixtures being investigated would be a large percentage of the breakage area and would possibly affect the strength results. This problem could be surmounted by designing a mold which would form larger briquets with larger breaking sections. This would also require designing pulling fixtures for testing the larger briquet.

Although the direct tensile method appeared to be the most promising method for testing, given the need for test equipment development, it was decided to conduct a series of tests this fiscal year (1987) using the splitting tensile method. The strength data thus derived from this testing could be used for preliminary engineering work if used conservatively and subject to verification.

\subsubsection{Splitting Tensile Tests}

Test procedure, PDT-107, "Determining Splitting Tensile Strength of Compacted Basalt/Bentonite Mixtures" (PNL 1987j), was written to conduct a matrix of splitting tensile tests. The procedure required 12 4-in. diameter, cylindrical specimens to be prepared and tested from each of the $85 \%$ basalt/ $15 \%$ bentonite and $75 \%$ basalt/25\% bentonite mixes. Each group of 12 was to be broken into two subgroups of six to be statically compacted at pressures $11,530 \mathrm{kPa}$ and $15920 \mathrm{kPa}(1672 * 33 \mathrm{psi}$ and $2308 * 46)$ psi, respectively. Also each static compaction pressure was to have an optimum moisture content associated with it: $10.8 \%$ for the lower static compaction pressure and $9.6 \%$ for the higher static compaction pressure. Then half of each group of six were to be oven dried for 48 hours at $105^{\circ} \mathrm{C}$. The specified static compaction pressures and related optimum target moisture contents were obtained from the earlier static compaction testing. This compaction pressure/ moisture content relationship is well illustrated in Figures 4 and 5 . It should also be noted that the $65 \%$ basalt/35\% bentonite mixture was not dealt with in this test matrix because of the limited task resources and because the $85 \%$ basalt/15\% bentonite and $75 \%$ basalt/25\% bentonite mixtures appeared to be the best candidates for higher strength based on earlier testing. This mix should be included in the test matrix at a later date. Note that at the writing of this report, only the $85 \% / 15 \%$ specimens had been prepared and tested. The activities on the $75 \% / 25 \%$ specimens are continuing. 


\subsection{CONCLUSIONS}

\subsection{CURRENT RESULTS}

\subsubsection{Gradations/Packing Mixtures}

\subsubsection{The Talbot Gradation}

Use of the Talbot gradation design has proven to be an effective foundation for the packing fabrication investigations. Scalping of the basalt fines and replacement with the equal amounts of bentonite also proved to be a satisfactory practice. At laboratory scale the preparation of the mixtures was not complicated by the scalping technique. Correct measurements of material weights and water percentages were easily achieved. Achievement of "as mixed for" water content including the mellowing mixtures procedures was successful. Thus far, these investigations have not discovered complications that would preclude the large-scale (full-size) packing fabrication using Talbot gradation basalt/bentonite mixtures. However, full-scale production batching needs to be considered.

\subsubsection{The Optimum Mixture}

The most optimum mixture, based on unconfined compressive and tensile strength testing is the $85 \%$ basalt/15\% bentonite, with $9.5 \%$ water content, and compacted with a hydraulic press at static pressure of $15,920 \mathrm{kPa}$ (2309 psi). Significantly, the $85 \%$ basalt $/ 15 \%$ bentonite mixture showed less dependency upon water content to achieve good results. Static hydraulic compaction of $75 \%$ basalt $/ 25 \%$ bentonite, with $10.0 \%$ water content at 15,920 kPa (2309 psi) also exhibited good results. However, the $85 \%$ basalt $/ 15 \%$ bentonite mixture consistently indicated better results at lower compaction loads, (see Appendix A for the compaction pressures). The lower compaction pressures have an added advantage of less energy consumption and the increased life expectancy of machinery. 


\subsubsection{Comparisons of Compaction Methods}

The Proctor Method, while effective in producing adequate results is, not as promising as the hydraulic static compaction method in the results achieved (dry densities), in ease of material placement and in the number of lifts required. In addition, the laboratory-scale hydraulic compaction method is less complicated than the Proctor method and is less prone to produce operator errors. In these investigations the Proctor method used five lifts; the static hydraulic compaction used only two and achieved higher results. Another feature of the hydraulic static compaction method is the ability to accurately control the load and the load rate. This feature will allow an optimum load that will produce the required dry density, yet, have the advantage of controlling particle breakage by choosing a lower compaction load, i.e., 11,530 kPa (1672 psi) vs $15,920 \mathrm{kPa}$ (2309 psi). As discussed in section 5.1.1.3, particle breakage does produce less dry density and changes the optimum water content. The reduction in compaction load, therefore, will also be a contributing factor in choosing the full-scale packing fabrication load. It is expected that the hydraulic compaction machine design of a fullscale operation would provide better production control than a design based on potential energy of dropped mass, i.e., a design based on a Proctor concept. Although the energy cost associated with full-scale packing will be a factor in choosing a compaction method, the principal criteria will be production control and product reliability. Other factors such as the cost of production or the production rate using either method (Proctor or hydraulic) are difficult to predict at this time. All of these factors, i.e., design cost, procurement costs, operational cost/production costs, labor, etc., will require careful analysis and justification before the final decision is made. It is expected that the full-scale prototypical packing ring testing/production will provide the answers to these prototypic questions. 


\subsubsection{Packing Dry Densities}

\subsubsection{Achievement of Minimal Densities}

Compaction testing and development activities, using established ASTM methods, i.e., Proctor and alternate compaction methods (hydraulic static compaction) were successfully achieved on a laboratory scale basis. The mixing and preparation of the mixtures was not a difficult task and, in general, the results indicate good repeatability. Adaptation of these methods to a large full-scale operation, although difficult, is not insurmountable.

The target dry density of $2.0 \mathrm{~g} / \mathrm{cm}^{3}\left(125 \mathrm{lb} / \mathrm{ft}^{3}\right)$ was achieved in all of the compaction tests with one exception. The exception was the $65 \%$ basalt/ $35 \%$ bentonite mixture compacted using the Proctor method. The Proctor results for both FY 86 and FY 87 indicated dry densities less than $2.0 \mathrm{~g} / \mathrm{cm}^{3}$ $\left(125 \mathrm{lb} / \mathrm{ft}^{3}\right.$ ) (see Figures 1 and 2). Although the compaction results of the $65 \%$ basalt $/ 35 \%$ bentonite mixture are not attractive (perhaps more investigation is needed, see Section 6.2. Additional Laboratory Scale Work), the preponderance of the evidence indicates that this mixture should not be pursued as a viable alternative unless driven by other factors such as the degradation of the basalt over time or necessity to obtain an adequate swelling pressure.

The compaction testing accomplished thus far demonstrates that the $85 \%$ basalt/15\% bentonite mixture is the most versatile and best performing design for the unconfined compressive and tensile strength tests. This mixture repeatedly produced the highest in dry density. In addition, the testing of this mixture indicates a trend of less dependency upon water content to achieve the acceptable dry density. This factor would allow some margin of error in the mix preparation process and could be less influenced by the atmospheric conditions during large-scale fabrications. 


\subsubsection{Packing Strength}

6.1.3.1 Unconfined Compressive Strength

Values of the unconfined compressive strength for the packing mixtures were equal to or exceeded initial expectations. Values of $2760 \mathrm{kPa}$ (400 psi) $3100 \mathrm{kPa}$ (450 psi) were thought to be a reasonable strength value when the testing investigation began. The upper values of $4140 \mathrm{kPa}(600 \mathrm{psi}$ ) (see Appendix D) for the $85 \%$ basalt/15\% bentonite, hydraulic static compacted samples, are commendable values that will add credibility to the establishment of a viable packing method. The $75 \%$ basalt $/ 25 \%$ bentonite mixture, hydraulic static compacted samples, also exhibited excellent strength values.

The unconfined compressive strength values of the $3790 \mathrm{kPa}(550 \mathrm{psi})$ to $4140 \mathrm{kPa}$ (600 psi) range are based on short-term oven drying, 48 to 72 hours, and not on long-term curing. Historically, evaluation of materials such as clay and clay/aggregate mixtures are analyzed for compressive strength in time of 0 to 30 days (Gates 1982). The current tests show that the intermediate strength (not ultimate strength) is improved by the extra 24 hours between the 48- and 72-hour oven drying times. Therefore, final analyses of the strength of these mixtures is thought to be contingent upon investigations of longer curing times. Nevertheless, the existing known values are encouraging and they support the basalt/bentonite packing fabrication hypothesis.

\subsubsection{Tensile Strength}

a. Comparison of Tensile Strength Testing Methods

As described in Section 5.2.2.1, Procedure Development, the calculated splitting tensile strength for the two trial specimens was about $276 \mathrm{kPa}$ and $152 \mathrm{kPa}$ (40 psi and $22 \mathrm{psi}$ ), respectively, for the moist and dried specimens. The ultimate strengths attained from the briquet tests ranged from $123 \mathrm{kPa}$ to $157 \mathrm{kPa}(17.8 \mathrm{psi}$ to $22.8 \mathrm{psi})$ for the dried specimens, and $92 \mathrm{kPa}$ to $186 \mathrm{kPa}$ (13.4 psi to $26.9 \mathrm{psi}$ ) for the moist specimens. It is difficult to draw firm conclusions from comparing the results from both test methods, especially because of the limited number of splitting tensile tests performed. However, the strengths do fall into the same general range. 
While the primary advantage of the indirect, splitting tensile strength method is its simplicity and low cost, it must be verified by further testing for use to determine the tensile strength of the basalt/bentonite packing material. This is indicated by several observations noted during the testing thus far. One is that considerable deformation of the cylinder surfaces occurs along the paths of load application by the loading plates, even with the use of softer bearing strips to help distribute the load axially. The deformation averaged $1.07 \mathrm{~mm}(0.042 \mathrm{in.})$, on a side, for the moist specimens, and $0.178 \mathrm{~mm}(0.007 \mathrm{in.})$, on a side, for the dry specimens. This deformation implies that the applied compressive load is being distributed laterally more than is desirable and thus will affect the splitting tensile stress results. Another observation is that the compressed material along the two opposing deformed paths may act as splitting wedges to some extent as they are pushed into the cylinder by the bearing strips. This may affect the splitting stress. Yet another related observation is that the visual evidence of splitting/cracking does not occur spontaneously which makes it difficult to determine when the specimen has actually split. This is especially so since the testing indicated that the applied load on the specimen will increase even after splitting has taken place (due apparently to the relatively higher compressive strength of the material) which makes rapid drop-off of the applied load a poor indicator of splitting as is normally used in the ASTM splitting tensile tests.

On the other hand, not enough experience was gained with the trial direct tensile tests using the briquets to know for sure if this method is directly applicable to testing the basalt/bentonite material for tensile strength, but a high probability of success may exist for using this method. It would require, however, a design effort to develop a larger briquet mold than is available for the standard ASTM test. Also this test method could hold promise as a means of verifying the splitting tensile test methodology for this material. 


\section{b. Splitting Tensile Test Results}

The test matrix and test results for the splitting tensile strength tests are shown in Table 13. Table 14 gives a condensed listing of the average splitting tensile strength values for the associated compaction pressures. Figure 20 illustrates the average splitting tensile strength vs compaction pressure with relationship to the various drying times.

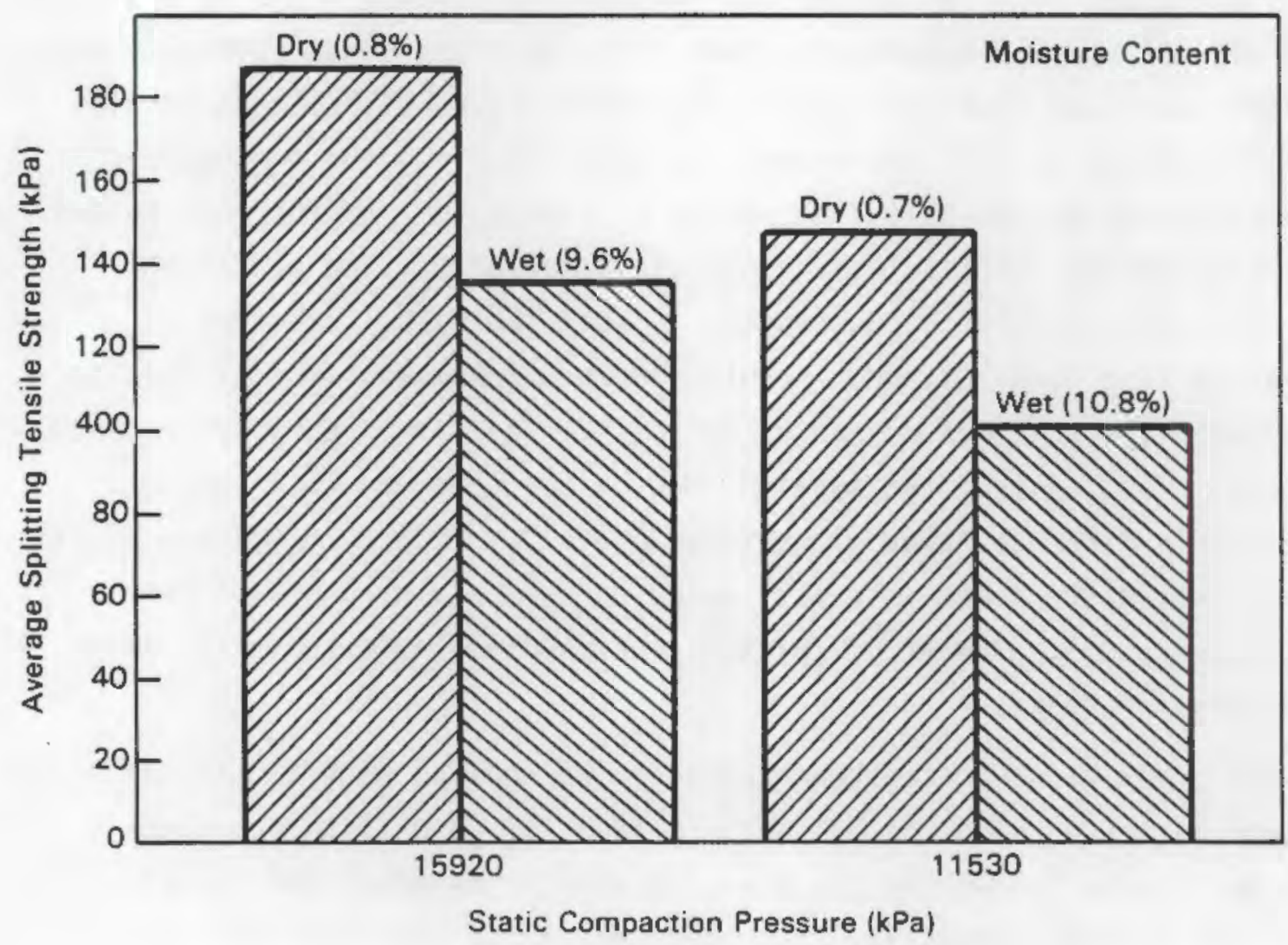

FIGURE 20. Splitting Tensile Strengths for $85 \%$ Basalt/ $15 \%$ Bentonite at $15,920 \mathrm{kPa}$ and $11,530 \mathrm{kPa}$ Compaction Pressures

SI onversion: $1 \mathrm{kPa}=6.89 \mathrm{psi}$ 
IABLE 13. Splitting Tensile Strength Test Matrix and Results

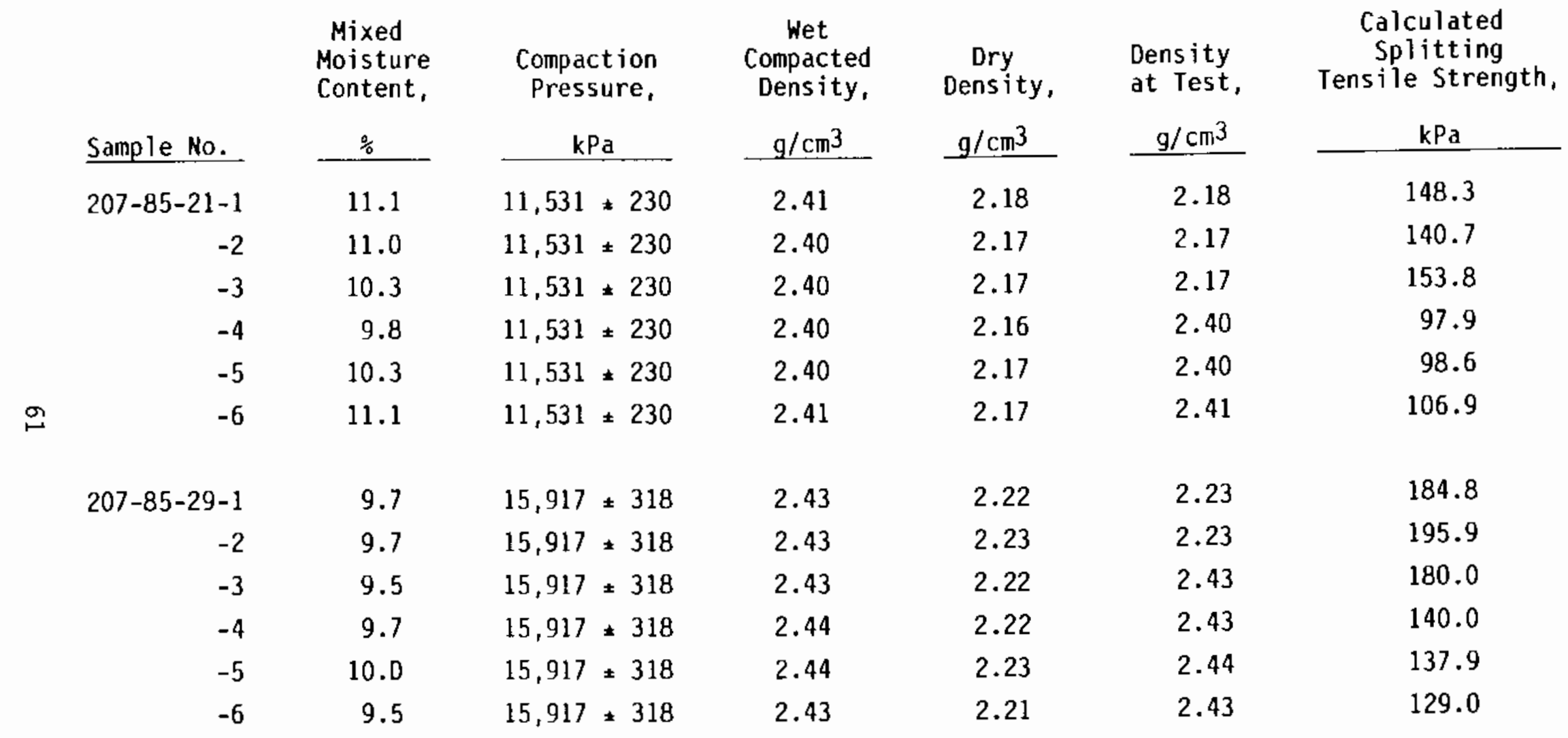

SI Conversion: $6.89 \mathrm{kPa}=1 \mathrm{psi} \quad 1 \mathrm{~g} / \mathrm{cm}^{3}=62.431 \mathrm{~b} / \mathrm{ft}^{3}$ 


\section{TABLE 14 Comparison of Average Splitting Tensile}

Strength with Compaction Pressure

\begin{tabular}{|c|c|c|c|}
\hline $\begin{array}{l}\text { Specimen } \\
\text { No. }\end{array}$ & $\begin{array}{c}\text { Compaction } \\
\text { Pressure } \\
\end{array}$ & $\begin{array}{l}\text { Average Compaction } \\
\text { Density } \\
\end{array}$ & $\begin{array}{l}\text { Average Splitting } \\
\text { Tensile Strength }\end{array}$ \\
\hline $\begin{array}{c}29-1-29-3 \\
\text { dry }\end{array}$ & $15,920 \mathrm{kPa}$ & $2.42 \mathrm{~g} / \mathrm{cm}^{3}$ & $187 \mathrm{kPa}$ \\
\hline $\begin{array}{c}29-4--29-6 \\
\text { moist }\end{array}$ & $15,920 \mathrm{kPa}$ & $2.44 \mathrm{~g} / \mathrm{cm}^{3}$ & $136 \mathrm{kPa}$ \\
\hline 21-1 $\underset{\text { dry }}{-21-3}$ & $11,530 \mathrm{kPa}$ & $2.40 \mathrm{~g} / \mathrm{cm}^{3}$ & $148 \mathrm{kPa}$ \\
\hline $\begin{array}{c}21-4--21-6 \\
\text { moist }\end{array}$ & $11,530 \mathrm{kPa}$ & $2.40 \mathrm{~g} / \mathrm{cm}^{3}$ & $101 \mathrm{kPa}$ \\
\hline
\end{tabular}

SI Conversion: $1 \mathrm{kPa}=6.89 \mathrm{psi} \quad 1 \mathrm{~g} / \mathrm{cm}^{3}=62.43 \mathrm{lb} / \mathrm{ft}^{3}$

For each set of six specimens, the three dried specimens yielded higher splitting tensile strengths than the three moist samples yielded. Interestingly, the achieved difference in densities between the two compacted lots was only $2.3 \%$ for the dried specimens and $1.1 \%$ for the moist specimens, yet yielded a much larger difference in strength. Therefore, high compaction pressures appear to be necessary for high tensile strength even though the relative densities may not increase proportionately. This also indicates that, unlike compressive strength, achieved density alone may not be a good indicator of tensile strength. 


\subsection{ADDITIONAL LABORATORY SCALE WORK}

Additional laboratory investigations are recommended to fully confirm the findings of the investigation thus far and to continue the laboratory scale efforts in the determination of the packing fabrication technique.

\subsubsection{Compaction of mixtures}

Compaction tests using the Proctor and hydraulic compaction should be continued.

- Mechanical mixing and batching techniques (stirring, kneading, time sequences, etc.) of the mixtures (basalt, bentonite and water) in larger batch sizes should be investigated. Methods of handling the large scale mixing process will be necessary for the full production of the packing.

- Additional Proctor tests are needed to establish a relationship of this method for possible use in the prototypical large packing rings handing and compaction machinery.

- Although hydraulic compaction appears to be the most promising method, it has not been conclusively shown to be the best method. Additional tests of mixtures at reduced loads are needed to fully confirm the merits of the hydraulic, static compaction method.

- A number of compaction tests have been carried out, however, this data is still limited in number. More data is required to fully evaluate the results.

\subsubsection{Drying methods}

- Affects of long-term curing, oven drying and atmospheric drying, should be investigated, especially in regard to large samples or the prototypic packing rings.

- Drying of the mixtures should be evaluated by application of drying method which are to a "constant mass." 


\subsubsection{Unconfined compressive strength tests}

- Additional tests are needed for all mixtures at lower static loads to establish design guides for compaction machinery and handling equipment.

- Additional tests are needed for the samples dried using the "constant mass" drying methods.

- Additional evaluation of particle breakage is needed to fully evaluate the performance of the packing with regard to gradation, changes in density and effect on water content.

\subsubsection{Tensile strength tests.}

- Fully develop a test matrix for preliminary load frame tensile testing of compacted samples.

- Investigate samples at dry and saturated conditions.

- Further investigate the packing for tensile strength as a function of its mixture. 


\section{REFERENCES}

ASTM 1986a, ASTM D4253-83, "Standard Test Methods for Maximum Index Density of Soils Using A Vibratory Table." 1986 Book of ASTM Standards Section 4, Volume 04.08. American Society of Testing and Materials.

ASTM 1986b, ASTM D-698-78, "Standard Test Methods for Moisture-Density Relations of Soils and Soil-Aggregate Mixture Using 5.5-1b (2.49-Kg) Rammer and 12-in. (305-mm) Drop." 1986 Book of ASTM Standards, Section 4, Volume 04.08. American Society for Testing and Materials.

ASTM 1986c, ASTM D1557-78, "Standard Test Methods for Moisture-Density Relations of Soils and Soil-Aggregate Mixture Using 10-1b (4.45 kg) Rammer and 18-in. (457 mm) Drop." 1986 Annual Book of ASTM Standards, Section 4, Vol. 04.08. American Society for Testing and Materials.

ASTM 1987a, ASTM C-496-86, "Standard Test Methods for Splitting Tensile Strength of Cylindrical Concrete Specimens," 1987 Book of ASTM Standards, Section 4, Volume 04.08. American Society For Testing and Materials.

ASTM 1987b, ASTM 03967-81, "Standard Test Methods for Splitting Tensile Strength of Intact Rock Core Specimens," 1987 Book of ASTM Standards, Section 4. Volume 04.02. American Society for Testing and Materials.

ASTM 1987C, ASTM C-190-85, "Standard Test Methods for Tensile Strength of Hydraulic Cement Mortar," 1987 Book of ASTM Standards, Section 4, Volume 04.01. American Society for Testing and Materials.

ASTM 1987d, ASTM D2166-85, "Standard Test Methods for Unconfined Compressive Strength of Cohesive Soil." 1987 Book of ASTM Standards, Section 4, Volume 04.08. American Society for Testing and Materials.

ASTM 1987e, ASTM D 2216-80, "Standard Test Methods for Laboratory Detemination of Water (Moisture) Content of Soil, Rock and Soil-Aggregate Mixtures", 1987 Book of ASTM Standards, Section 4. Volume 04.08. American Society for Testing and Materials.

PNL 1986, TAL-1. 1986. "Calculation Work Sheet, Talbot Basalt Only Gradation." EPD-200 BWIP Packing Development Testing, Pacific Northwest Laboratory, Richland, Washington.

PNL 1987a, DSG-1, "Calibration Work Sheet, Detemination of Specific Gravity," 1987, L2E2DP, BWIP, Packing Fabrication Task, Pacific Northwest Laboratory, Richland, Washington.

PNL 1987b, DPC-1. 1987. "Calculation Work Sheet, Acceptability of Precision Calculations." Packing Calibration Task, L2E2DP, Pacific Northwest Laboratory, Richland, Washington. 
PNL 1987c Technical Procedure PDT-104, Rev. 0, ICN. \#P0T-104-1. 1987. "Conducting Mixing and Mellowing Tests of Bentonite and Basalt Bentonite Mixtures." Pacific Northwest Laboratory, Richland, Washington.

PNL 1987e, Technical Procedure PDT-105, Rev. 0, ICN, PDT-105-1. 1987. "Determining the Density and Moisture Content of Basalt/Bentonite Mixtures Compacted by Alternate Methods." Pacific Northwest Laboratory, Richland, Washington.

PNL 1987f, Technical Procedure PDT-106, Rev. 0, ICN. \#PDT-106-1. 1987. "Determining the Unconfined Compressive Strength of Compacted Basalt/Bentonite Mixtures." Pacific Northwest Laboratory, Richland, Washington.

PNL 1987g, "Packing Development Testing Procedure Assignments," May 1987, Project L2E2DP, Packing Development Testing, Pacific Northwest Laboratory, Richland, Washington.

PNL 1987h, Technical Procedures PDT-101, Rev. 1, ICN. \#PDT-101-1. 1987. "Sieving of Soils and Aggregates." Pacific Northwest Laboratory, Richland, Washington.

PNL 1987i, Technical Test Instruction, PDT-205-1. 1987. "Tests of Basalt/Bentonite Mixtures Using an Alternate Static Press Compaction Method." Pacific Northwest Laboratory, Richland, Washington.

PNL 1987j, Technical Procedure PDT-107, Rev. 0, "Determining the Splitting Tensile Strength of Compacted Basalt/Bentonite Mixtures." Pacific Northwest Laboratory, Richland, Washington.

Gates, T. E., 1982, "Geotechnical Properties of Paraho Spent Shale," Pacific Northwest Laboratory, Richland, Washington, PNL-4357.

Kaufman, L.P., et al., 1979, "Suggested Method for the Calibration of Vibrating Tables for Maximum Index Density Testing," Geotechnical Testing Journal, GTJODJ, Vol.2, No.2, September 1979, pp. 152-157.

Talbot, R. N. 1983. The Strength of Concrete: Its Relation to Cement, Aggregate, and Water. Bulletin No. 137, University of Illinois. 
APPENDIX A

STATIC COMPACTION TESTS

A. 1 
APPENDIX A

8WIP5.WK1

PDT -105

STATIC COMPACTION TESTS W/REPEATS

R=REPEAT

SAMPLE :MOIST. \%MOIST. DENSITY DENS1TY DENS1TY WEIGHT PERCENT \#FORCE NUMBER MIXED FOR OBTA1NED DRY(PFC) DRY $(\mathrm{g} / \mathrm{cm} 3)$ WET(PCF) COM.SOIL BE/BA COMPACTED

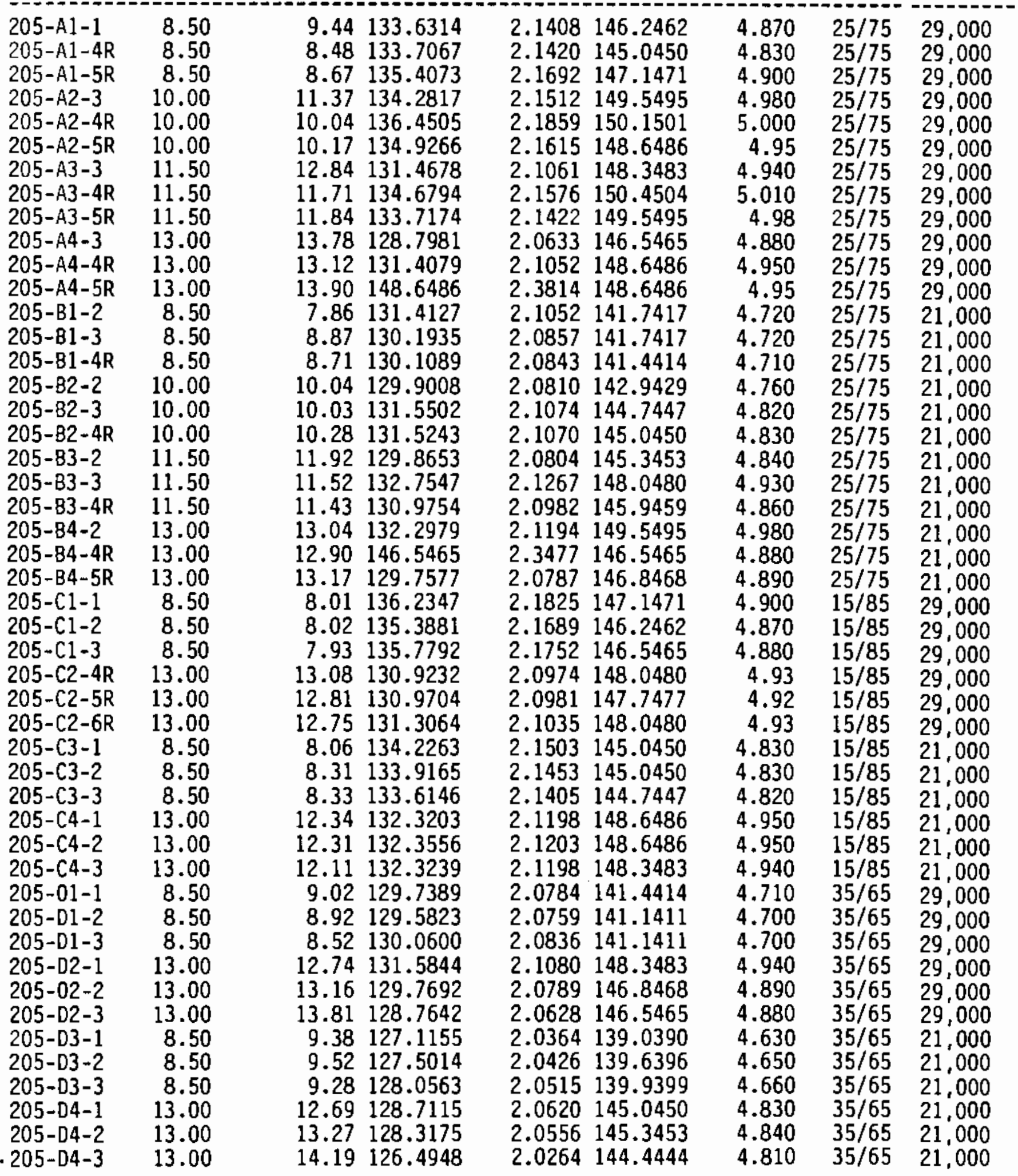




$\begin{array}{lrrllllll}205-E 1-1 & 8.50 & 9.29 & 129.1436 & 2.0689 & 141.1411 & 4.700 & 25 / 7525,000 \\ 205-E 2-1 & 13.00 & 13.29130 .4155 & 2.0893147 .7477 & 4.920 & 25 / 7525,000 \\ 205-E 2-2 & 13.00 & 12.93 & 128.9698 & 2.0661 & 145.6456 & 4.850 & 25 / 7525,000 \\ 205-E 3-1 & 8.50 & 8.33137 .4955 & 2.2027 & 148.9489 & 4.960 & 15 / 8525,000 \\ 205-E 3-2 & 8.50 & 8.89 & 137.3400 & 2.2002 & 149.5495 & 4.980 & 15 / 8525,000 \\ 205-E 4-1 & 13.00 & 11.83 & 134.8034 & 2.1596 & 150.7507 & 5.020 & 15 / 8525,000 \\ 205-E 5-1 & 11.50 & 11.80142 .6426 & 2.2851142 .6426 & 4.750 & 35 / 6525,000\end{array}$

\section{Legend for Sample Nunber}

EXAMPLE: $205-\mathrm{Al}-1$

$205=$ The first three numbers stand for test instruction PDT-205.

$A 1=$ The middle letter/number refers to the various mix ratios and moisture contents the test matrix of POT-205, where:

$A=75 / 25 \quad B=75 / 25 \quad C=85 / 15 \quad D=65 / 35 \quad E=$ RANDOM TESTS;

$1=$ through 4 were for the spectfics of each test test read left to right to identify the $\mathrm{mix}$ water content. See Table 8 , page 19. matrix in PDT-205 3.3.2, from left to right.

$l=$ The last number refers to the individual sample number

$R=$ Indicates that the test is a repeat test. 
APPENDIX B

PRECISION CALCULATIONS

$O F$

STATIC COMPACTION RESULTS

B. 1 
APPENDIX B

PRECISION CALC. 205-A1

$\begin{array}{ccc} & \text { DRY } & \text { MOISTURE } \\ & \text { DENSITY CONTENT } \\ & -1408 & 9.4400 \\ 205-A 1-1 & 2.1408 \\ 205-A 1-4 R & 2.1402 & 8.4800 \\ 205-A 1-5 R & 2.1692 & 8.6724\end{array}$

\begin{tabular}{ccc}
$Y=$ AVG. & 2.150066 & 8.864133 \\
\hline$(X-Y)$ & 0.000085 & 0.331622 \\
squared & 0.000097 & 0.147558 \\
& 0.000366 & 0.036761
\end{tabular}

\begin{tabular}{ccc} 
SUM & 0.000549 & 0.515942 \\
\hline SUm/2 & 0.000274 & 0.257971 \\
\hdashline SQ.RT.SUm $/ 2$ & 0.016572 & 0.507908
\end{tabular}

$X=$ INDIVIDUAL VALUE OF EACH DETERMINATION $Y=N U M E R I C A L$ AVG. OF THE DETERMINATIONS

PRECISION CALC. 205-A3

\begin{tabular}{|c|c|c|}
\hline & $\begin{array}{c}\text { DRY } \\
\text { DENSITY }\end{array}$ & $\begin{array}{l}\text { MOISTURE } \\
\text { CONTENT }\end{array}$ \\
\hline $\begin{array}{l}205-A 3-3 \\
205-A 3-4 R \\
205-A 3-5 R\end{array}$ & $\begin{array}{l}2.1061 \\
2.1576 \\
2.1421\end{array}$ & $\begin{array}{l}12.8400 \\
11.7100 \\
11.8441\end{array}$ \\
\hline$Y=A V G$. & 2.135266 & 12.13136 \\
\hline $\begin{array}{c}(X-Y) \\
\text { squared }\end{array}$ & $\begin{array}{l}0.000850 \\
0.000498 \\
0.000046\end{array}$ & $\begin{array}{l}0.502161 \\
0.177549 \\
0.082522\end{array}$ \\
\hline SUM & 0.001396 & 0.762233 \\
\hline Sum/2 & 0.000698 & 0.381116 \\
\hline RT Sum & 0.026421 & \\
\hline
\end{tabular}

PRECISION CALC. 205-A2

$\begin{array}{rcc} & \text { DRY } & \text { MOISTURE } \\ & \text { DENSITY CONTENT } \\ & -1.1512 & 11.3700 \\ 205-A 2-3 & 2.150 \\ 205-A 2-4 R & 2.1859 & 10.0400 \\ 205-A 2-5 R & 2.1615 & 10.1689\end{array}$

\begin{tabular}{ccc} 
SUM & 0.000635 & 1.076052 \\
\hline Sum/2 & 0.000317 & 0.538026 \\
\hline SQ.RT.SUm/2 & 0.017821 & 0.733502
\end{tabular}

PRECISION CALC. 205-A4

\begin{tabular}{ccc} 
& DRY & MOISTURE \\
& DENSITY CONTENT \\
205-A4-3 & 2.0633 & 13.7800 \\
$205-A 4-4 R$ & 2.1052 & 13.1200 \\
$205-A 4-5 R$ & 2.1056 & 13.0939 \\
& & \\
Y AVG. & 2.091366 & 13.3313 \\
\hline X-Y) & 0.000787 & 0.201331 \\
Squared & 0.000191 & 0.044647 \\
& 0.000202 & 0.056358 \\
& & \\
\hline SUM & 0.001181 & 0.302338 \\
\hline Sum $/ 2$ & 0.000590 & 0.151169 \\
\hline SQ.RT.Sum/2 & 0.024307 & 0.388804
\end{tabular}

B.'2 
PRECISION CALC. 205-B1

$\begin{array}{lcc} & \text { DRY } & \text { MOISTURE } \\ & \text { DENSITY } & \text { CONTENT } \\ & -1052 & 7.8600 \\ 205-B 1-2 & 2.1052 & 8.8700 \\ 205-B 1-3 & 2.0857 & 8.7071\end{array}$

PRECISION CALC, 205-B3

\begin{tabular}{ccc} 
& DRY & MOISTURE \\
& DENSITY & CONTENT \\
$205-B 3-2$ & 2.0804 & 11.9200 \\
$205-B 3-3$ & 2.1267 & 11.5200 \\
$205-B 3-4 R$ & 2.0982 & 11.4320 \\
& & \\
Y AVG. & 2.101766 & 11.624 \\
\hline (X-Y) & 0.000456 & 0.087616 \\
squared & 0.000621 & 0.010816 \\
& 0.000012 & 0.036864
\end{tabular}

\begin{tabular}{ccc} 
SUM & 0.001090 & 0.135296 \\
Sum/2 & 0.000545 & 0.067648 \\
\hline SQ.RT.Sum $/ 2$ & 0.023355 & 0.260092
\end{tabular}

PRECISION CALC. 205-B2

\begin{tabular}{|c|c|c|}
\hline & $\begin{array}{c}\text { DRY } \\
\text { DENSITY }\end{array}$ & $\begin{array}{l}\text { MOISTURE } \\
\text { CONTENT }\end{array}$ \\
\hline $\begin{array}{r}205-B 2-2 \\
205-B 2-3 \\
205-B 2-4 R\end{array}$ & $\begin{array}{l}2.0810 \\
2.1074 \\
2.1070\end{array}$ & $\begin{array}{l}10.0400 \\
10.0300 \\
10.2795\end{array}$ \\
\hline$Y=A V G$. & 2.098466 & 10.1165 \\
\hline $\begin{array}{c}(X-Y) \\
\text { squared }\end{array}$ & $\begin{array}{l}0.000305 \\
0.000079 \\
0.000072\end{array}$ & $\begin{array}{l}0.005852 \\
0.007482 \\
0.026569\end{array}$ \\
\hline SUM & 0.000457 & 0.039903 \\
\hline Sum/2 & 0.000228 & 0.019951 \\
\hline . RT.Sun & & \\
\hline
\end{tabular}

PRECISION CALC. 205-B4

\begin{tabular}{|c|c|c|}
\hline & $\begin{array}{c}\text { DRY } \\
\text { DENSITY }\end{array}$ & $\begin{array}{l}\text { MOISTURE } \\
\text { CONTENT }\end{array}$ \\
\hline $\begin{array}{r}205-B 4-2 \\
205-B 4-4 R \\
205-B 4-5 R\end{array}$ & $\begin{array}{l}2.1194 \\
2.0795 \\
2.0787\end{array}$ & $\begin{array}{l}13.0400 \\
12.8954 \\
13.1691\end{array}$ \\
\hline$Y=A V G$. & 2.092533 & 13.03483 \\
\hline $\begin{array}{c}(X-Y) \\
\text { squared }\end{array}$ & $\begin{array}{l}0.000721 \\
0.000169 \\
0.000191\end{array}$ & $\begin{array}{l}0.000026 \\
0.019441 \\
0.018027\end{array}$ \\
\hline SUM & 0.001083 & 0.037495 \\
\hline Sum $/ 2$ & 0.000541 & 0.018747 \\
\hline $10 \mathrm{QT} \quad 5 \mathrm{O}$ & 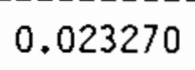 & 11 \\
\hline
\end{tabular}


PRECISION CALC. 205-C1

\begin{tabular}{|c|c|c|}
\hline & $\begin{array}{c}\text { DRY } \\
\text { DENSITY }\end{array}$ & $\begin{array}{l}\text { MOISTURE } \\
\text { CONTENT }\end{array}$ \\
\hline $\begin{array}{l}205-C 1-1 \\
205-C 1-2 \\
205-C 1-3\end{array}$ & $\begin{array}{l}2.1825 \\
2.1689 \\
2.1753\end{array}$ & $\begin{array}{l}8.0113 \\
8.0208 \\
7.9257\end{array}$ \\
\hline$Y=A V G$. & 2.175566 & 7.985933 \\
\hline $\begin{array}{c}(X-Y) \\
\text { squared }\end{array}$ & $\begin{array}{l}0.000048 \\
0.000044 \\
0.000000\end{array}$ & $\begin{array}{l}0.000643 \\
0.001215 \\
0.003628\end{array}$ \\
\hline SUM & 0.000092 & 0.005487 \\
\hline Sum $/ 2$ & 0.000046 & 0.002743 \\
\hline SQ.RT.SU & 0.0 & 0 \\
\hline
\end{tabular}

PRECISION CALC. 205-C3

\begin{tabular}{|c|c|c|}
\hline & $\begin{array}{c}\text { DRY } \\
\text { DENSITY }\end{array}$ & $\begin{array}{l}\text { MOISTURE } \\
\text { CONTENT }\end{array}$ \\
\hline $\begin{array}{l}205-C 3-1 \\
205-C 3-2 \\
205-C 3-3\end{array}$ & $\begin{array}{l}2.1502 \\
2.1454 \\
2.1404\end{array}$ & $\begin{array}{l}8.0647 \\
8.3062 \\
8.3331\end{array}$ \\
\hline$Y=A V G$. & 2.145333 & 8.234666 \\
\hline $\begin{array}{c}(X-Y) \\
\text { squared }\end{array}$ & $\begin{array}{l}0.000023 \\
0.000000 \\
0.000024\end{array}$ & $\begin{array}{l}0.028888 \\
0.005117 \\
0.009689\end{array}$ \\
\hline SUM & 0.000048 & 0.043694 \\
\hline Sum $/ 2$ & 0.000024 & 0.021847 \\
\hline SQ.RT. Sum/ & 0.004900 & 0.147808 \\
\hline
\end{tabular}

PRECISION CALC. 205-C2

\begin{tabular}{|c|c|c|}
\hline & $\begin{array}{c}\text { DRY } \\
\text { DENSITY }\end{array}$ & $\begin{array}{l}\text { MOISTURE } \\
\text { CONTENT }\end{array}$ \\
\hline $\begin{array}{l}205-C 2-4 R \\
205-C 2-5 R \\
205-C 2-6 R\end{array}$ & $\begin{array}{r}2.0973 \\
2.0981 \\
2.1035\end{array}$ & $\begin{array}{l}13.0832 \\
12.8140 \\
12.7500\end{array}$ \\
\hline$Y=A V G$. & 2.099633 & 12.8824 \\
\hline $\begin{array}{c}(X-Y) \\
\text { squared }\end{array}$ & $\begin{array}{l}0.000005 \\
0.000002 \\
0.000014\end{array}$ & $\begin{array}{l}0.040320 \\
0.004678 \\
0.017529\end{array}$ \\
\hline SUM & 0.000022 & 0.062528 \\
\hline Sum/2 & 0.000011 & 0.031264 \\
\hline
\end{tabular}

PRECISION CALC. 205-C4

\begin{tabular}{|c|c|c|}
\hline & $\begin{array}{c}\text { DRY } \\
\text { DENSITY }\end{array}$ & $\begin{array}{l}\text { MOISTURE } \\
\text { CONTENT }\end{array}$ \\
\hline $\begin{array}{l}205-C 4-1 \\
205-C 4-2 \\
205-C 4-3\end{array}$ & $\begin{array}{l}2.1198 \\
2.1204 \\
2.1199\end{array}$ & $\begin{array}{l}12.3380 \\
12.3060 \\
12.1071\end{array}$ \\
\hline$Y=A V G$. & 2.120033 & 12.25036 \\
\hline $\begin{array}{c}(X-Y) \\
\text { squared }\end{array}$ & $\begin{array}{l}0.000000 \\
0.000000 \\
0.000000\end{array}$ & $\begin{array}{l}0.007679 \\
0.003095 \\
0.020525\end{array}$ \\
\hline SUM & 0.000000 & 0.031300 \\
\hline Sum/2 & 0.000000 & 0.015650 \\
\hline
\end{tabular}


APPENDIX B

PRECISION CALC. 205-D1

\begin{tabular}{ccc} 
& DRY & MOISTURE \\
& DENSITY CONTENT \\
$205-D 1-1$ & 2.0784 & 9.0184 \\
$205-D 1-2$ & 2.0760 & 8.9178 \\
$205-D 1-3$ & 2.0835 & 8.5245 \\
& & \\
Y AVG. & 2.0793 & 8.820233 \\
\hline X-Y) & 0.000000 & 0.039270 \\
squared & 0.000010 & 0.009519 \\
& 0.000017 & 0.087458 \\
& & \\
\hline SUM & 0.000029 & 0.136247 \\
\hline Sum $/ 2$ & 0.000014 & 0.068123 \\
\hline SQ.RT.SUm/2 & 0.003830 & 0.261005
\end{tabular}

PRECISION CALC. 205-D3

\begin{tabular}{|c|c|c|}
\hline & $\begin{array}{c}\text { DRY } \\
\text { DENSITY }\end{array}$ & $\begin{array}{l}\text { MOISTURE } \\
\text { CONTENT }\end{array}$ \\
\hline $\begin{array}{l}205-D 3-1 \\
205-D 3-2 \\
205-D 3-3\end{array}$ & $\begin{array}{l}2.0365 \\
2.0426 \\
2.0515\end{array}$ & $\begin{array}{l}9.3760 \\
9.5163 \\
9.2767\end{array}$ \\
\hline$Y=A V G$. & 2.043533 & 9.389666 \\
\hline $\begin{array}{c}(X-Y) \\
\text { squared }\end{array}$ & $\begin{array}{l}0.000049 \\
0.000000 \\
0.000063\end{array}$ & $\begin{array}{l}0.000186 \\
0.016036 \\
0.012761\end{array}$ \\
\hline
\end{tabular}

\begin{tabular}{ccc} 
SUM & 0.000113 & 0.028984 \\
\hline Sum/2 & 0.000056 & 0.014492 \\
\hline SQ.RT . Sum $/ 2$ & 0.007543 & 0.120383
\end{tabular}

PRECISION CALC. 205-D2

\begin{tabular}{|c|c|c|}
\hline & $\begin{array}{c}\text { DRY } \\
\text { DENSITY }\end{array}$ & $\begin{array}{l}\text { MOISTURE } \\
\text { CONTENT }\end{array}$ \\
\hline $\begin{array}{l}205-D 2-1 \\
205-D 2-2 \\
205-D 2-3\end{array}$ & $\begin{array}{l}2.1080 \\
2.0789 \\
2.0629\end{array}$ & $\begin{array}{l}12.7373 \\
13.1587 \\
13.8067\end{array}$ \\
\hline$Y=A V G$. & 2.083266 & 13.23423 \\
\hline $\begin{array}{c}(X-Y) \\
\text { squared }\end{array}$ & $\begin{array}{l}0.000611 \\
0.000019 \\
0.000414\end{array}$ & $\begin{array}{l}0.246942 \\
0.005705 \\
0.327718\end{array}$ \\
\hline SUM & 0.001045 & 0.580366 \\
\hline Sum $/ 2$ & 0.000522 & 0.290183 \\
\hline RT.SU & & \\
\hline
\end{tabular}

PRECISION CALC. 205-D4

\begin{tabular}{|c|c|c|}
\hline & $\begin{array}{c}\text { DRY } \\
\text { DENSITY }\end{array}$ & $\begin{array}{l}\text { MOISTURE } \\
\text { CONTENT }\end{array}$ \\
\hline $\begin{array}{l}205-D 4-1 \\
205-D 4-2 \\
205-D 4-3\end{array}$ & $\begin{array}{l}2.0620 \\
2.0556 \\
2.0265\end{array}$ & $\begin{array}{l}12.6897 \\
13.2743 \\
14.1855\end{array}$ \\
\hline$Y=A V G$. & 2.048033 & 13.38316 \\
\hline $\begin{array}{l}(X-Y) \\
\text { squared }\end{array}$ & $\begin{array}{l}0.000195 \\
0.000057 \\
0.000463\end{array}$ & $\begin{array}{l}0.480896 \\
0.011851 \\
0.643738\end{array}$ \\
\hline SUM & 0.000716 & 1.136486 \\
\hline Sum/2 & 0.000358 & 0.568243 \\
\hline RT.Su & & \\
\hline
\end{tabular}


APPENDIX $B$

PRECISION CALC. $2065 C 8529$

\begin{tabular}{lcc} 
& DRY & MOISTURE \\
& DENSITY & CONTENT \\
\hline $206 S C 85291$ & 2.2344 & 9.1585 \\
$2065 C 85292$ & 2.1981 & 9.3236 \\
$2065 C 85293$ & 2.2095 & 9.5221
\end{tabular}

$\begin{array}{ccc}Y=\text { AVG. } & 2.214 & 9.334733 \\ (X-Y) & 0.000416 & 0.031058 \\ \text { squared } & 0.000252 & 0.000123 \\ & 0.000020 & 0.035106\end{array}$

\begin{tabular}{ccc} 
SUM & 0.000689 & 0.066288 \\
\hline Sum/ $/ 2$ & 0.000344 & 0.033144 \\
\hline SQ.RT.Sum $/ 2$ & 0.018563 & 0.182055
\end{tabular}

PRECISION CALC. 206 SC8521

\begin{tabular}{ccc} 
& DRY & MOISTURE \\
& DENSITY CONTENT \\
206SC85211 & 2.1057 & 9.4331 \\
$206 S C 85212$ & 2.1644 & 9.5804 \\
$206 S C 85213$ & 2.1446 & 9.9177 \\
& & \\
Y AVG. & 2.138233 & 9.643733 \\
\hline (X-Y) & 0.001058 & 0.044366 \\
squared & 0.000684 & 0.004011 \\
& 0.000040 & 0.075057 \\
& & \\
\hline SUM & 0.001783 & 0.123435 \\
\hline Sum/2 & 0.000891 & 0.061717 \\
\hline SQ.RT.SUm/2 & 0.029863 & 0.248430
\end{tabular}




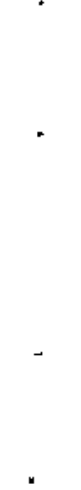


APPENDIX C

RANGE PERCENTAGE OF

MEAN VALUES MULTI-LAB PRECISION

C. 1 


\section{RANGE $\%$ OF MEAN VALUE MULTI-LAB PRECISION \\ 205-A1 \\ DRY MOISTURE \\ DENSITY CONTENT \\ 2.1500668 .864133 AVG.0F3 \\ 0.029 \\ 0.96 MOST DIFF. \\ $1.348810 .8302 \%$ OF MEAN VAL.}

APPENDIX C

205-A2

\begin{tabular}{|c|c|c|}
\hline $\begin{array}{c}\text { DRY } \\
\text { DENSITY }\end{array}$ & $\begin{array}{l}\text { MOISTURE } \\
\text { CONTENT }\end{array}$ & \\
\hline 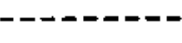 & ------ & \\
\hline $\begin{array}{l}2.1662 \\
0.0347 \\
1.6019\end{array}$ & $\begin{array}{r}10.5263 \\
1.33 \mathrm{M} \\
12.6350 \%\end{array}$ & $\begin{array}{l}\text { AVG.OF3 } \\
\text { MOST DIFF. } \\
\text { \%OF MEAN VAL. }\end{array}$ \\
\hline
\end{tabular}

205-A4

\begin{tabular}{ccc} 
DRY & MOISTURE \\
DENSITY & CONTENT \\
\hline 2.091366 & 13.3313 & AVG. OF3 \\
0.0423 & 0.6861 & MOST DIFF. \\
2.0226 & $5.1465 \% 0 F$ MEAN VAL.
\end{tabular}

205-B2

\begin{tabular}{cr} 
DRY & MOISTURE \\
DENSITY & CONTENT \\
\hline 2.098466 & 10.1165 AVG.OF3 \\
0.0264 & 0.2495 MOST DIFF. \\
1.2581 & 2.4663 \%OF MEAN VAL.
\end{tabular}

205-B4

\begin{tabular}{ccc} 
DRY & MOISTURE \\
DENSITY & CONTENT & \\
\hline 2.092533 & 13.03483 & AVG.OF3 \\
0.0407 & 0.2737 & MOST DIFF. \\
1.9450 & 2.0998 & $\%$ OF MEAN VAL.
\end{tabular}

$205-C 2$

\begin{tabular}{cc} 
DRY & MOISTURE \\
DENSITY & CONTENT \\
\hline 2.099633 & 12.8824 AVG.OF3 \\
0.0062 & 0.3332 MOST DIFF. \\
0.2953 & 2.5865 \%OF MEAN VAL.
\end{tabular}




\begin{tabular}{ccc}
$205-\mathrm{C} 3$ & \\
DRY & MOISTURE \\
DENSITY & CONTENT & \\
\hline 2.145333 & 8.234666 & AVG.OF3 \\
0.0098 & 0.2684 & MOST DIFF. \\
0.4568 & 3.2594 \%OF MEAN VAL.
\end{tabular}

205-D1

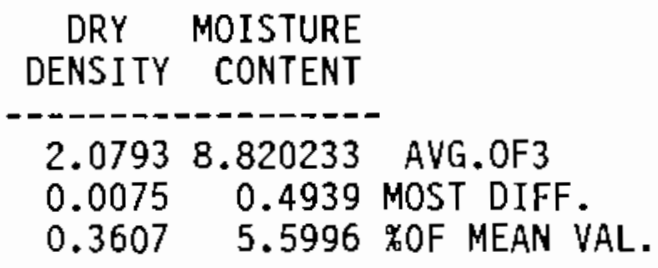

205-D3

DRY MOISTURE

DENSITY CONTENT

2.0435339 .389666 AVG.0F3

0.0150 .2396 MOST DIFF.

$0.7340 \quad 2.5517 \% 0 F$ MEAN VAL.

$2065 C 8529$

DRY MOISTURE

DENSITY CONTENT

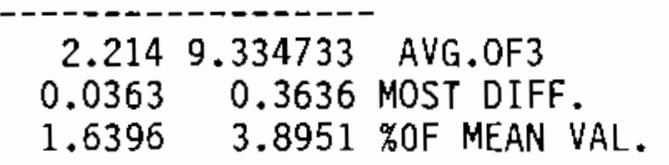

205-C4

\begin{tabular}{ccc} 
DRY & MOISTURE \\
DENSITY CONTENT & \\
\hline 2.120033 & 12.25036 & AVG. OF3 \\
0.0006 & 0.2309 & MOST DIFF. \\
0.0283 & 1.8848 & \%OF MEAN VAL.
\end{tabular}

205-D2

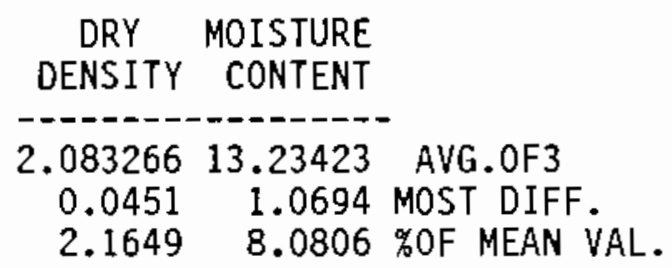

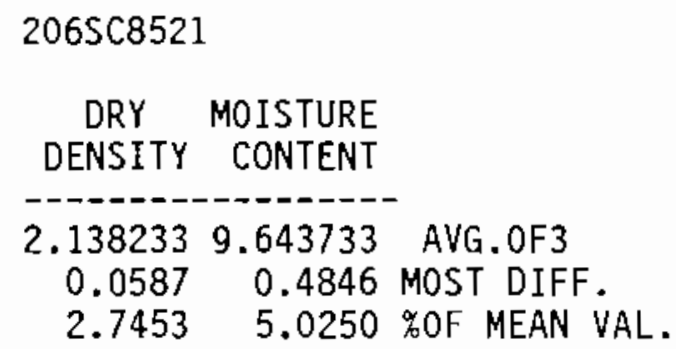


APPENDIX D

UNCONFINED COMPRESSIVE TEST RESULTS

PROCTOR AND HYDRAULIC STATIC COMPACTION METHODS

D. 1 
APPENDIX D PDT-166

UNCONFINED CONPRESSION TEST

SAMPLE DRY-TIUE UNCONFINED AVG.CROSS AXIAL DENSITY DENSITY APP.FORCE CONT. INITIAL INITIAL CHANGE DRY NUMBER HETHCD COMP.STRNGT SEC.AREA STRAIN \#/FT3 G/CM3 OFAILURE $\$$ DIAMETE HEIGHT HEIGHT WEIGHT

\begin{tabular}{|c|c|c|c|c|c|c|c|c|c|c|c|c|c|}
\hline $266-P-85-2$ & $24 \mathrm{HR}$ & IEN & 54.1460 & 3.5749 & D. .743 & 29.26 & 9707 & 459.80 & 1. 3095 & 4.6060 & 4.6277 & 0.3438 & 4.407 \\
\hline $6-P-85-4$ & $24 \mathrm{HR}$ & IEN & 54.9983 & 3.4512 & 0.0672 & 29.83 & 98 & 439.06 & .3639 & 3.9978 & 4.6517 & อ. 3125 & 4.445 \\
\hline $8-P-85-5$ & $3 H R$ & EN & 36.2828 & 3776 & 608 & 29.35 & & 000.08 & 1696 & .0000 & 8377 & 913 & 4.370 \\
\hline $6-P-85-B$ & $24 \mathrm{HR}$ & & & & .9472 & 80 & & & & & 33 & 88 & .418 \\
\hline $6-P-85-7$ & $8 H R$ & EN & & & & 20.014 & & & & 4.0000 & & & .362 \\
\hline$-85-8$ & $24 H R$ & TSD & 193 & 3.0774 & 9.9410 & 28.12 & & 30.90 & 9.8582 & 3.9960 & 4.5737 & & 4.672 \\
\hline $86-P-85-9$ & BHR & IEN & 32.3790 & 3.2461 & 6. 0608 & 31.27 & & 300.00 & .0169 & 00 & .6273 & 0.2813 & 4.374 \\
\hline $286-P-85-16$ & $72 \mathrm{HR}$ & IEN & & & & & & & & 990 & 4.8107 & 38 & 4. 356 \\
\hline $266-P-85-11$ & $72 \mathrm{HR}$ & EN & & & & & & & & & & & .350 \\
\hline $268-P-85-12$ & $24 \mathrm{HR}$ & SSD & & 75 & & 29.38 & & & & 3.9970 & 4.6667 & & \\
\hline $5-13$ & $2 \mathrm{HR}$ & EN & 292 & 3.2843 & 0.0548 & 29.48 & & 10.98 & 199 & 89 & & 566 & 4.360 \\
\hline $6 S C$ & & & & & & 38.73 & & 10.06 & 293 & 4.0000 & 393 & 6.2 & 4.645 \\
\hline $65 \operatorname{CSBS} 29-5$ & $2 H R$ & & & 82 & & & & & & & & & 4. 629 \\
\hline $6 \operatorname{Sc} 85$ & $24 H R$ & & & & & 36. & & 0.96 & 140 & 9968 & & & \\
\hline $29-7$ & $2 \mathrm{HR}$ & & & & & 37.48 & & & & & .6447 & 63 & \\
\hline $6 \mathrm{SC} 8529-8$ & $24 \mathrm{KR}$ & & & & & 5 & & & & & & & 4.635 \\
\hline $3529-9$ & BHR & EN & & 58 & 6 & 38. & & & & & & & \\
\hline $\operatorname{sSC6529-16}$ & $2 \mathrm{HR}$ & EN & & & & 36.7 & & 8.60 & 1705 & & & & \\
\hline $6 \mathrm{~S}$ & 2HR & & & & & 36. & & 3.66 & & 4. & 123 & & \\
\hline $66 S C 8529-12$ & $72 \mathrm{HR}$ & JTO & & & & & & & & & 28 & & 4.915 \\
\hline $365 C 8529-13$ & $8 H R$ & EN & 85 & 13.3 & 0.8 & 137.22 & & 72 & & & & & 4.646 \\
\hline 165 & & & & 13.1 & 0.0 & 138.45 & & 0.90 & 990 & & & & \\
\hline 865 & & & & & & 35.31 & & 0.00 & 169 & 4.8 & 177 & & \\
\hline $206 \mathrm{SC} 8529-16$ & $24 H R$ & JTO & & 13.0 & & & & & 514 & 4.0000 & 347 & 0.1 & \\
\hline $206 \mathrm{SC} 7529-1$ & $24 H R$ & EN & 69.4 & 13.0249 & 9.9 & 133. & & & & & & & 4.610 \\
\hline $9-2$ & & & & 13.2694 & 0.0504 & 133.94 & & 7000.00 & 6.3 & & & & 556 \\
\hline $2065 \mathrm{SC} 7529-3$ & & & & & & 135.48 & 01 & 0.60 & 1.8465 & 4.0030 & & & \\
\hline $206 S C 7529-4$ & $48 \mathrm{HR}$ & VEN & 48 & 13.3570 & 0.8 & 1 & & 9.00 & 9.2188 & 4.0046 & 347 & 6.2 & \\
\hline $29-5$ & $4 H R$ & VEN & 18.3573 & 13.4696 & 0.0605 & 133.3 & & .00 & 455 & 4.6650 & .6467 & 0. 2813 & 4.560 \\
\hline $29-6$ & $H R$ & EN & 408 & 3.3419 & 0.0572 & 134.19 & & .60 & & & & 0.2 & 4.545 \\
\hline $685 C 7521-1$ & & & & 546 & 0.0571 & 132.66 & 2.1156 & 8.60 & 0.1647 & 4. & & & .486 \\
\hline $865 C 7521-2$ & $24 \mathrm{HR}$ & VEN & 52 & 13.4804 & 6.6 & 136.49 & 2.6904 & 4300.00 & 1.7878 & 4.0040 & 4.6500 & & 4.510 \\
\hline $6 S C 7521-3$ & $48 \mathrm{HR}$ & OVEN & 86.6629 & 13.2493 & 6.0566 & 131.32 & 37 & 0.00 & 6.0326 & 4.0020 & 4.6327 & 0.2 & 4.436 \\
\hline $65 C 7521-4$ & $24 \mathrm{HR}$ & VEN & 6134 & 13.34 & 9.9572 & 131.58 & 79 & 4790.99 & 1.1792 & 4.0020 & 4.6433 & g. 2656 & 4.506 \\
\hline $2665 C 7521-5$ & $48 H R$ & OVEN & 8 & 13.2131 & 9.6470 & 133.56 & & 8630.00 & 0.0783 & 4.0040 & 4.6 & 0.2188 & 4.530 \\
\hline $16 S C 7521-6$ & $24 H R$ & OVEN & 429.8333 & 13.1214 & 0.0404 & 132.63 & 2.1248 & 5646.00 & 0.4981 & 4.0848 & 4.6433 & D. 1875 & 4.510 \\
\hline
\end{tabular}

Legend: 206 (SC or P) 8529 - where:

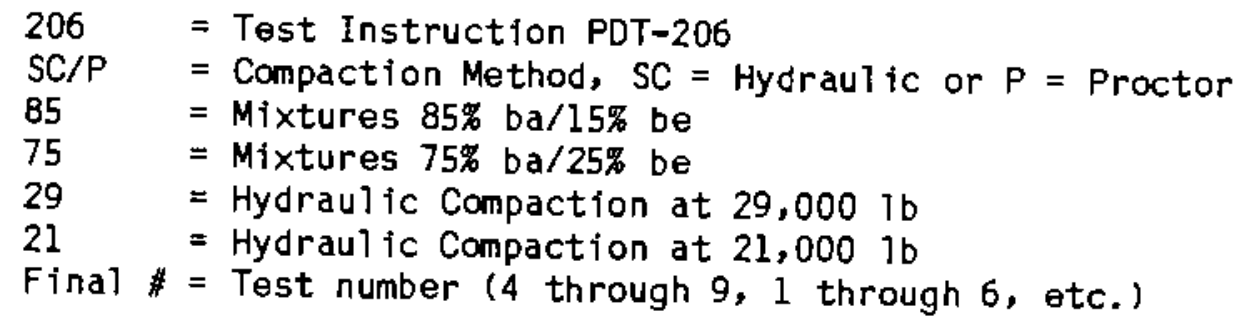




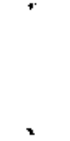




\section{DISTRIBUTION}

No. of

Copies

\section{OFFSITE}

10 DoE Office of Scientific and Technical Information

9 DOE Office of Civilian Radioactive Waste Management Forrestal Building Washington, DC 20585

ATTN: D. H. Alexander, RW-232

L. H. Barrett, RW-33

A. Berusch, RW-231

C. R. Cooley, RH-4

N. Eisenberg, RH-232

J. R. Hilley, RW-30

S. Kale, RH-20

D. E. Shelor, $R W-32$

R. Stein, RW-23

3 DOE Office of Defense Waste \& Transportation Management GTN Washington, DC 20545

ATTN: T. C. Chee, DP-123

G. H. Daly, OP-124

J. E. Lytle, DP-12

4 DOE Office of Remedial Action \& Waste Technology GTN

Washington, DC 20545

ATTN: J. A. Coleman, NE-24

T. W. McIntosh, NE-24

W. R. Voigt, NE-20

H. F. Walter, NE-24

A. T. Clark

Division of Fuel Material Safety Nuclear Regulatory Commission Washington, DC 20555
No. of

Copies

V. Stello

Office of the Executive

Director for Operations

Nuclear Regulatory Commission

Mail Station 6209

Washington, DC 20555

G. L. Sjoblom

Environmental Protection Agency

Office of Radiation Programs

401 M Street, S.W.

Washington, DC 20460

J. M. McGough

DOE Albuquerque Operations

Office

P.0. Box 5400

Albuquerque, NM 87185

P. G. Hagan

Joint Integration Office

Bldg. 3, 2nd Floor

2201 San Pedro N.E.

Albuquerque, NM 87110

E. Maestas

DOE West Valley Operations

Office

P.0. Box 191

West Valley, NY 14171

2 DOE Idaho Operations Office

550 Second Street

Idaho Falls, I0 83401

ATTN: S. T. Hinschberger

J. P. Hamric 
No. of

Copies

F. T. Fong

DOE San Francisco Operations

1333 Broadway

Oakland, CA 94612

C. A. Givens

2905 9th St. NW

Albuquerque, NM 87107

M. R. Jugan

DOE Oak Ridge Operations Office

P.O. Box $E$

Oak Rjdge, TN 37830

W. J. Brumley

DOE Savannah River Operations

Office

P.0. Box A

Aiken, SC 29801

M. J. Steindler

Argonne National Laboratory

9700 South Cass Avenue

Argonne, IL 60439

C. S. Abrans

Argonne National Laboratory

P.0. Box 2528

Idaho Falls, ID 83401

D. Schweitzer

Brookhaven National Laboratory

Upton, NY 11973

K. Pruess

Lawrence Berkeley Laboratory

Berkeley, CA 94720

3 Battelle Memorial Institute

Project Management Division

505 King Avenue

Columbus, OH 43201

ATTN: H. A. Carbeiner

W. S. Madia

Technical Library
No. of

Copies

L. D. Ramspott

Lawrence Livermore Nationa]

Laboratory

University of California

P.0. Box 808

Livermore, CA 94550

D. T. Oakley, MS 619

Los Alamos Scientific Laboratory

P.0. Box 1663

Los Alamos, NM 87544

4 Oak Ridge National Laboratory

P.0. Box Y

Dak Ridge, TN 37830

ATTN: J. 0. Blomeke

W. D. Burch

R. T. Jubin

L. J. Mezga

3 Sandia Laboratories

P.0. Box 5800

Albuquerque, NM 87185

ATTN: R. W. Lynch

T. 0 . Hunter

Technical Library

J. R. Berreth

Westinghouse Idaho Nuclear

Co. , Inc.

P.0. Box 4000

Idaho Falls, ID 83401

6 E. I. du Pont de Nemours

Company

Savannah River Laboratory

Aiken, SC 29801

ATTN: R. G. Baxter

M. D. Boersma

J. G. Glasscock

J. R. Knight

M. J. Plodinec

C. T. Randal? 
No. of

$\underline{\text { Copies }}$

E. A. Jennrich

EG\&G Idaho

P.0. Box 1625

Idaho Falls, ID 83415

\section{R. Shaw}

Electric Power Research

Institute

3412 Hillview Avenue

P.0. Box 10412

Palo Alto, CA 94304

5 West Valley Nuclear Services Company

P.0. Box 191

West Valley, NY 14171

ATTN: C. C. Chapman

J. C. Cwynar

J. E. Krauss

S. J. Marchette

J. M. Pope

J. L. White, Chairman

Energy Research \& Development Authority

Empire State Plaza

Albany, NY 12223

F. B. Cheung

Department of Mechanical

Engineering

The Pennsylvania State

University

University Park, PA 16802

\section{ONSITE}

9 DOE Richland Operations Office

E. A. Bracken

C. E. Collantes

C. R. DeLannoy

N. T. Karagianes

P. E. Lamont

J. M. Peterson
No. of

Copies
J. L. Rhoades
M. W. Shupe
J. D. White

16 Westinghouse Hanford Company

R. C. Arnett

BWIP Library

T. A. Curran

R. W. Forester

E. A. Fredenburg

R. L. Gilchrist

J. Graham

J. C. Krogness

M. Kummerer

R. E. Lerch

T. B. McCall

A. F. Noonan

S. B. Sonnichsen

R. 0 . Vaddey

J. D. Watrous

S. C. Yung

53 Pacific Northwest Laboratory

C. R. Allen

L. L. Ames

W. W. Ballard, Jr.

M. C. C. Bampton

W. F. Bonner

D. J. Bradley

G. H. Bryan

H. C. Burkholder

J. R. Burnell

K. S. Cabbage (3)

T. T. Claudson

R. D. Dierks

L. E. Eary

J. D. Eklund (3)

T. E. Gates (5)

G. W. Gee

B. M. Johnson 
No. of

Copies

R. S. Kemper

D. E. Knowlton

W. L. Kuhn

W. W. Laity

L. T. Lakey

D. E. Larson

V. C. Lauhala

J. L. McElroy

M. A. McKinnon

J. E. Mende1/M. R. Kreiter

P. F. Salter

J. B. Schuette

C. W. Stewart

R. A. Stokes

A. P. Toste

E. V. Werry (5)

J. H. Westsik, Jr.

Publishing Coordination (2)

Technical Report Files (5) 